\title{
Amphibians of the Eleven Contiguous Western States and Alaska
}

\author{
by
}

\author{
Allan E. Thomas
}

Graphics by Harriet Thomas

Illustrations by Robin Bracewell

Prepared for

The Bureau of Land Management c/o Idaho State Office 1387 S. Vinnell Way

Boise, Idaho 83709

by

Idaho Department of Fish and Game 600 S. Walnut, P.O. Box 25

Boise, Idaho 83707

July 2001 
O

O

○ 


\section{AMPHIBIANS OF THE ELEVEN CONTIGUOUS WESTERN STATES AND ALASKA}

TABLE OF CONTENTS

\section{Introduction}

Key to Status Rankings

Amphibians (published in alphabetical order of common name)

Amargosa Toad

Arboreal Salamander

Barking Frog

Black Salamander

Black Toad

Bullfrog

California Newt

California Slender Salamander

Canadian Toad

Canyon Treefrog

Cascades Frog

Chiricahua Leopard Frog

Clouded Salamander

Coeur d'Alene Salamander

Columbia Spotted Frog

Cope's Giant Salamander

Couch's Spadefoot

Del Norte Salamander

Dunn's Salamander

Ensatina

Foothill Yellow-legged Frog

Great Basin Spadefoot

Great Plains Narrowmouth Toad

Great Plains Toad

Green Toad

Idaho Giant Salamander

Jemez Mountains Salamander

Kern Canyon Slender Salamander

Larch Mountain Salamander

Limestone Salamander

Long-toed Salamander

Lowland Leopard Frog

Mount LyellSalamander

Mountain Treefrog 
O

0

○ 
(Amphibians, continued)

Mountain Yellow-legged Frog

Northern Casque-headed Frog

Northern Cricket Frog

Northern Leopard Frog

Northwestern Salamander

Olympic Salamander

Oregon Slender Salamander

Oregon Spotted Frog

Pacific Chorus Frog

Pacific Giant Salamander

Plains Leopard Frog

Plains Spadefoot

Red-bellied Newt

Red-legged Frog

Red-spotted Toad

Relictual Slender Salamander

Rio Grande Frog

Roughskin Newt

Sacramento Mountain Salamander

Shasta Salamander

Sonoran Desert Toad

Sonoran Green Toad

Southern Spadefoot

Southwestern Toad

Striped Chorus Frog

Tailed Frog

Tarahumara Frog

Tehachapi Slender Salamander

Texas Toad

Tiger Salamander

Van Dyke's Salamander

Western Redback Salamander

Western Spadefoot

Western Toad

Wood Frog

Woodhouse's toad

Yosemite Toad

Status of Amphibians by States

Important sources of Amphibian Information 
○

0

0 


\section{Introduction}

I'll start with a major understatement: Amphibians have been around a long time. Amphibia is the world's oldest terrestrial vertebrate class at some 350 million years of age. Amphibians have been on the planet long before and ever since the dinosaurs. Their diversity is truly amazing. They have adapted to live in aquatic environments, wetlands, forests, deserts, savannas, agricultural developments, and in urban environments. I am a recently-retired BLM biologist with a strong interest inamphibians and the recovery of declining species. As you read throughthe species accounts that follow, even the amphibian "experts" among you should find surprises in the differences in food habits, habitats used, life histories, and even how little we know about some of them.

Suddenly, many amphibian populations are declining around the world and so me have become extinct. It appears the more we think we understand this decline, the more mysterious it becomes. Are amphibians like a "canary of the coal mine" telling us of dangers we are facing? Will we (or can we) act to stop the decline? We have the moral and legal responsibility to try.

For possible reasons for amphibian declines and information about the values of amphibians, I refer you to the articles "Amphibian Declines: An Issue Overview" by Reaser (2000) and "Why The Amphibians?" by Mattoon (2000). A quick list of possible causes would include (1) habitat loss, especially anything that would raise the temperature and reduce humidity, (2) toxins from industrial toxins and agricultural runoff, both as chemical herbicides and fertilizers, (3) increased exposure to ultraviolet light from weakening of the ozone layer, (4) introduction of exotic species such as bullfrogs, (5) intensive stocking of trout into new waters, (6) diseases, such as virulent, waterborne patho gens such as chytrid fungus, irido virses, and bacterium, (7) climate changes, and (8) even such seemingly innocent activities such as fishermen dumping their excess "nightcrawlers" after fishing trips and the ex otic worms consuming humus on the forest floor to a degree that reduces habitat for salamanders. Habitat loss is probably the largest cause of amphibian declines and the area that the Bureau of Land Management (BLM) can have the most influence.

The BLM contracted with the Idaho Department of Fish and Game (IDFG) for this guide for several purposes. The agency has the responsibility to ensure that no species having populations or habitat under their management is allowed to become ext inct due to their management activities. The BLM is working with numerous other agencies and groups to discover causes for recent amphibian declines and seeking ways to recover them. The IDFG has been a strong cooperator with BLM in this effort through its Non-Game Program. The purpose of this guide is to bring together information on the amphibians in the western United States where most BLM lands are located, as a quick reference to where the amphibians are, what their habits are, possible reasons for declines, and key references to aid in planning and management. Species are listed in alphabetical order of common names for the simple reason ofallowing specialists and managers to quickly find information on species where they may only have a name on a list. Pages are not numbered to allow the insertion of updated information on the amphibians such as status, taxonomy, and habits, without making the guide obsolete. 
○

0

. 
I have restricted the species accounts to 71 species for the eleven western states and Alaska that the BLM ismost interested in. While taxonomists are busily "lumping and splitting" populat ions of similar amphibians into additional or fewer species or subspecies, in most cases all necessary information is not yet known to develop a useful account. Important subspecies and iso lated populations certainly exist that need special management consideration, and I've tried to indicate them on the species accounts, with the "Status by states" list, and with the reference lists. Common names, scientific names, and federal, global, and state rankings were developed in part using www.natureserve.org. The BLM sensitive species were acquired from individual st ate coordinators, recognizing that the BLM sensitive species lists are under revision and some may change. For instance, I could acquire no information about the Alaska worm salamander other than the name.

The Important Sources of Amphibian Information section lists key references for the western United States and various regions or states, some specific references for certain species and groups of amphibians, some general references, and a number of amphibian reports which were developed by BLM specialists or their cooperat ors through efforts such as the Chal lenge Cost Shareprogram. From one to three of these references were selected as "Important References" for each species account, although information from additional references often was used. The book by Stebbins (1985) was used for most species accounts as it appeared to be the overall best from the standpoint of descriptions and distributions. For regional references, the most important references were Csuti et al. (1997) and Groves et al. (1997) for the Pacific Northwest, Verner and Boss (1980) for California, Degenhardt et al. (1996) for the Southwest, and Baxter and Stone (1980) and Hammerson (1999) for the Wyoming-Colorado vicinity. I'm sure that there are other important references that I did not find. Of special usefulness, are the "Photographic Identification Cards for Idaho Amphibians by Peterson and Fabian (1997). These cards are ideal for field use and contain nearly all information necessary for the identification of all stages of Idaho amphibians. The development of these cards was partly financed by BLM, and similar cards for all states should be encouraged.

I am indebted to those BLM state coor dinators who not only supplied me with information about the status of amphibians in their areas, but also turned me on to the key references in their regions, and sometimes even supplied me with copies. I also thank Dr. Chuck Peters on of Idaho State University, Dr. Gary Fellers of USGS in California, Dr. Chuck Harris of the Idaho Department of Fish and Game Department, and Jill Silvey of the BLM Washington Office for their help with the project. Finally, without the map-making and other computer skills of my wife Harriet and the artist ic skills of my daughter Robin, this product never would have been completed. 
○

0

○ 


\section{KEY TO STATUS RANKINGS:}

\section{GLOBAL}

$\mathbf{G X}=$ Presumed Extinct

$\mathbf{G H}=$ Historical

G1 = Critically Imperiled

G2 = Imperiled

G3 = Vulnerable

G4=Apparently Secure

G5 = Secure

$\mathbf{G U}=$ Unrankable

G? = Not Yet Ranked

\section{STATE}

$\mathbf{S X}=$ Presumed Extirpated

SH=Historical

S1 = Critically Imperiled

S2 = Imperiled

S3 $=$ Vulnerable

S4 = Apparently Secure

S5 $=$ Secure

$\mathbf{S Z}=$ Zero Occurrences

$\mathbf{S U}=$ Unrankable

$\mathbf{S R}=$ Reported

S? = Not Yet Ranked

SE $=$ Exotic 
0

0

O 


\title{
Amargosa Toad
}

\author{
Bufo nelsoni \\ Family Bufonidae
}

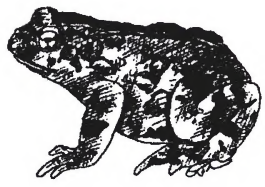

BLM Status: Sensitive (NV)

Global Rank: G1G2

State Rank: S1S2 (NV)

Distribution: Known only from the Amargosa River Valley (Oasis Valley) in vicinity of Springdale and Beatty, Nye County, Nevada. Sometimes considered as a subspecies of the western toad, Bufo boreas nelsoni.

Description: Adults reach up to 3 in. (7.5 $\mathrm{cm}$.) in snout-vent length. Resembles western toad except that head is more narrow, snout longer, and limbs shorter. The elbows and knees do not touch when placed along sides with body held straight. Dorsal ground color may be brownish. Adult females become larger than males.

Reproduction: Breeding occurs in the spring (mid-March to early April) with the eggs being

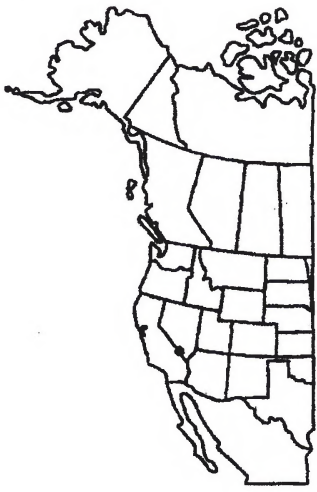
laid in two long, intertwined strands of gel, each containing thousands of eggs. The strands are laid on the bottom of slow moving water or wrapped around sedges and branches. Current range of the Amargosa toad Eggs hatch in few days and may be found in dense aggregations. Larvae probably metamorphose the first summer. 
Food: Adult Amargosa toads eat flying insects, spiders, crayfish, sowbugs, and earthworms. Larvae feed on algae and bottom detritus and filter suspended plant material.

Habits: Amargosa toads are usually found near water. They are diurnal in the spring and become nocturnal in the summer. They are associated with wetlands emergent vegetation and surrounding transitional and upland habitats. Home ranges average about 73 meters for males and $\mathbf{4 5}$ meters for females.

Management Implication: A FWS status review in 1996 showed that the toad was more abundant and widespread then previously believed and listing as endangered was not warranted. This finding was partly based on work by the Nevada Division of Wildlife, the Nevada Natural Heritage Program, the Bureau of Land Management, and others to conserve the species. It is classified as a sensitive species by Nevada BLM.

Important References: Stebbins, R.C. 1985. A field guide to western reptiles and amphibians. The Peterson Field Guide Series, Houghton Mifflin Company, New York, NY; Nevada Division of Wildlife. 2000. Population monitoring of the Amargosa toad (Bufo nelsoni) and habitat evaluation in Oasis Valley, Nevada. Nevada Division of Wildlife, Reno, NV. 


\title{
Arboreal Salamander
}

\author{
Aneides lugubris \\ Family Plethodontidae
}

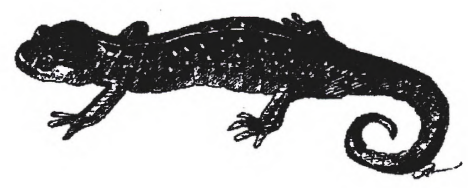

Global Rank: G5

State Rank: S4 (CA)

Distribution: Extends from the coastal mountains and valleys of California in Humbolt County to northwestern Baja California, and from coastal islands to foothills of the Sierra Nevada. Ranges from near sea level to around $5,000 \mathrm{ft} .(1,520 \mathrm{~m}$ ) in elevation. Often found in association with interior live oak habitats.

Description: Adult arboreal salamanders reach up to $4 \mathrm{in}$. $(10 \mathrm{~cm}$.) in snout-vent length. Coloration is usually plain brown with yellow spotting on dorsal surfaces, and whitish and unmarked below. Enlarged jaw muscles give the head a triangle shape. Toes have enlarged, squarish tips. There are usually 15 costal grooves. The tail is prehensile and usually coiled when the salamander is at rest. The young are dark above, and clouded with light gray or brassy coloration and rust or brassy

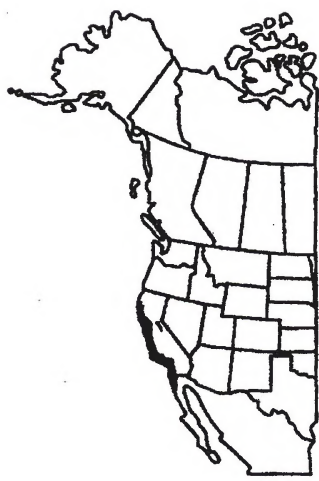

marks on the snout, on each side above forelimbs and base of limbs, and along the upper surface of the tail. Adult males have chunky, broad heads with powerful jaw mus- 
cles and a heart-shaped mental gland. Large adults can bite severely, but are not usually prone to do so. It sometimes squeaks when first caught.

Reproduction: Eggs are laid in May to June in moist habitats under surface objects, in logs, and occasionally up in trees. Peak activity is around early June and the mean clutch size is 17 (12 to 23 ) young.

Food: Searches or waits for insects and other invertebrates under surface objects. Also eats some fungi.

Habits: Occurs chiefly in coastal live-oak woodland, but ranges into forests of ponderosa pine and black oak, especially in the Sierra Nevada. Found both on the ground and in trees. Uses damp, underground burrows in summer dry weather. Found under logs, boards, and rocks, and under the bark of standing or fallen dead trees. Large numbers may aggregate in tree hollows.

Management Implications: Common in preferred foothills habitat.

Important References: Stebbins, R.C. 1985. A field guide to western reptiles and amphibians. The Peterson Field Guide Series, Houghton Mifflin Company, New York, NY; Verner, J., and A.S. Boss. 1980. California wildlife and their habitats: Western Sierra Nevada. USDA Pacific Southwest Forest and Range Experiment Station, GTR PSW-37, Berkeley, CA. 


\section{Barking Frog}

\section{Hylactophryne augusti}

Family Leptodactylidae

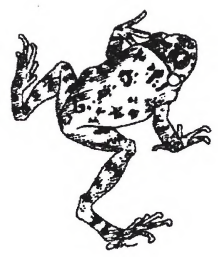

Adult

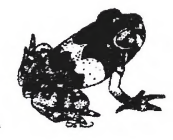

Young
Global Rank: G4

State Rank: S1 (AZ); S2 (NM)

Distribution: The barking frog (also known by the genus Eleutherodactylus) extends from southeastern Arizona and southeastern New Mexico to central Texas, and south through central and western Mexico to the Isthmus of Tehuantepec. In Mexico, it ranges from near sea level to $8,900 \mathrm{ft}$. $(2,710 \mathrm{~m}$.). Distribution is spotty. There are at least three subspecies: western, eastern, and Mexican. In Arizona, it is only known from a few specimens from the Santa Rita and Pajarito Mountains, and these are the northern extension of the western subspecies. In New Mexico, it is considered a relic, disjunct population of the Chihuahuan Desert, and is only known from isolated locations in Chaves, Eddy, and Otero Counties. The only established populations are near Carlsbad, New Mexico.

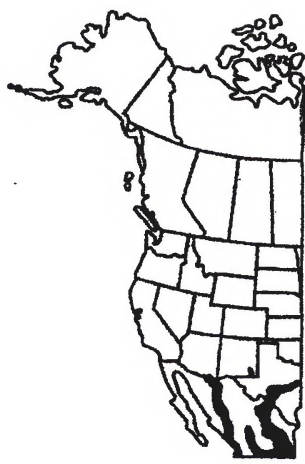

Current range of the barking frog 
Description: Adults reach up to 3.75 in. (9.5 $\mathrm{cm}$.) in snout-vent length. The barking frog is toadlike in shape, but toes are slender and unwebbed, with prominent tubercles beneath the joints. It has folds of skin across the back of the head and a circular fold on the belly. Eardrums are smooth and semitransparent. Coloration is greenish to light brown above, marked with dark blotches that often have light borders. Eggs are a conspicuous brown color. They walk in a stilted fashion with the hindquarters and heels well off the ground. Young have a distinctive light band across the back. Adult males are much smaller than the females. The voice resembles the bark of a small dog with a series of rapid yapping notes.

Reproduction: The peak of breeding activity occurs in April and May, with possibly a long and complex mating pattern. Eggs are laid in a cluster in a small cavity in soil under rocks, especially during periods of rainfall. Eggs are large yolked and unpigmented. The egg clusters may include up to $67 \mathrm{eggs}$, and need moisture to hatch. The males remain with the egg clusters and may provide needed moisture through excretion. Young emerge fully formed after metamorphosis is completed within the egg.

Food: Food habits of the barking frog are largely unknown. However, it is known that they will eat camel crickets and land snails.

Habits: The barking frog is a secretive, terrestrial, and often rock-dwelling species, frequently found in limestone areas. It hides by day under rocks and in mines, wells, caves, and fissures. It ranges from treeless, dry, yucca-covered hills or brushy woodlands to open pine forests.

Management Implications: Although the family is well represented in the American tropics, the barking frog is very rare in the
United States, and the only known established population in the West is near Carlsbad, New Mexico.

Important References: Stebbins, R.C. 1985. A field guide to western reptiles and amphibians. The Peterson Field Guide Series, Houghton Mifflin Company, New York, NY; Degenhardt, W.G., C.W. Painter, and A.H. Price. 1996. Amphibians and reptiles of New Mexico. University of New Mexico Press, Albuquerque, NM. 


\title{
Black Salamander
}

\author{
Aneides flavipunctatus
}

Family Plethodontidae

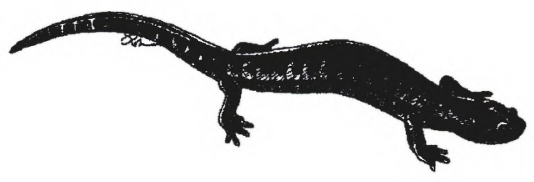

Global Rank: G4

State Rank: S2 (OR); S4 (CA)

Distribution: Found from the mountains of Jackson and Josephine Counties, Oregon, south in California to Shasta Lake area. Ranges from near sea level to over $5,500 \mathrm{ft}$. $(1,700 \mathrm{~m}$.) in elevation. Lives in all successional stages of digger pine-oak, chaparral, ponderosa pine, black oak woodland, and mixed-conifer types. Also occur in wet mountain meadows and riparian deciduous types. Not thought to be territorial with suspected home range of about one acre.

Description: Adult black salamanders reach about $2.7 \mathrm{in} .(9.4 \mathrm{~cm}$.) in snout-vent body length. Dorsal coloration varies greatly from uniformly black, black with small white flecks, black with large white spots; black with gray, olive, or green spots; or black with many small

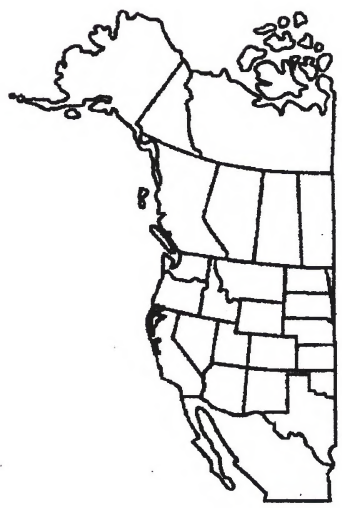
white spots. Projecting upper-jaw teeth and triangular head, 14-16 costal grooves, short limbs, and rounded toe tips are characteristics. Young are black above, often suffused with olive or green, and yellow bases of limbs. Adult males have heart-shaped mental gland 
and small gray glands on belly.

Reproduction: Approximately 15 (5 to 30 ) eggs are laid in moist places under surface objects from June through August. Peak activity is in July. Females have been found brooding their eggs in summer.

Food: Feeds on a variety of terrestrial invertebrates, including spiders, snails, slugs, earthworms, beetles, and springtails. The diet varies seasonally, and larger individuals take larger prey items.

Habits: The black salamander is chiefly ground-dwelling, usually found near streams, in talus slopes, or under rocks and logs. It inhabits open woodlands, mixed coniferous, and mixed coniferous-deciduous forests. Although rarely completely immersed in water, it appears to be more tolerant of wet soil than other climbing salamanders.

Management Implications: No known management concerns. Common in preferred habitats.

Important References: Stebbins, R.C. 1985. A field guide to western reptiles and amphibians. The Peterson Field Guide Series, Houghton Mifflin Company, New York, NY; Csuti, B., A.J. Kimerling, T.A. O'Neil, M.M. Shaughnessy, E.P. Gaines, and M.M.P. Huso. 1997. Atlas of Oregon wildlife. Oregon State University Press, Corvallis, OR; Verner, J., and A.S. Boss. 1980. California wildlife and their habitats: Western Sierra Nevada. USDA Pacific Southwest Forest and Range Experiment Station, GTR PSW-37, Berkeley, CA. 


\section{Black Toad}

\section{Bufo exsul \\ Family Bufonidae}

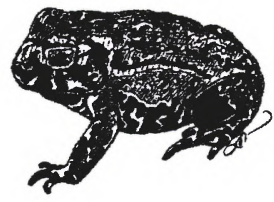

Global Rank: G1

State Rank: S1 (CA)

Distribution: Restricted to Deep Springs Valley, Inyo County, California, at about $5,000 \mathrm{ft}$. (1,520 m.) elevation. A population, apparently introduced, at nearby Antelope Springs may have died out.

Description: Adults reach up to $23 / 8$ in. (6.2 $\mathrm{cm}$.) in snout-vent length. Toads are small, lack cranial crests, but have oval parotoid glands. Dorsal coloration is heavy dark-olive to black mottling separated by light wavy marks. There usually is a light stripe down the middle of the back and heavy black blotches on the belly. Young are olive-colored above with yellow-orange foot tubercles becoming whitish or cream colored as individuals become older. Adult males with pale, unmarked or lightly spotted throat patches similar to females.

Reproduction: Breeds mainly from late

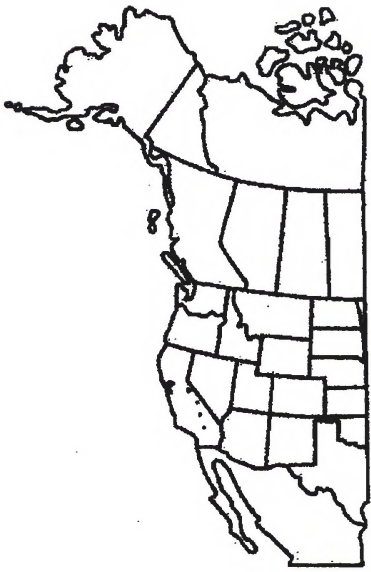
March to May. Voice is a weak chirp. Eggs laid in two long, intertwined strands of gel, each containing thousands of eggs. Eggs hatch within a week and larvae probably transform Current range of the black toad the first summer. 
Food: Similar to western toad in that adults eat all types of flying insects, spiders, crayfish, sowbugs, and earthworms. Larvae eat algae, bottom detritus and filtered suspended plant material.

Habits: Found only in marshes of grass, sedge, and related aquatic vegetation formed by water flows from springs of Deep Springs Valley. Highly aquatic, diurnal except becomes nocturnal during warmer weather. Active from late March to mid-September.

Management Implication: On the California endangered species list.

Important References: Stebbins, R.C. 1985. A field guide to western reptiles and amphibians. The Peterson Field Guide Series, Houghton Mifflin Company, New York, NY; Behler, J.L., and F.W. King. 2000. Field guide to North American reptiles and amphibians. National Audubon Society, Alfred A. Knopf, New York, NY. 


\section{Bullfrog}

\section{Rana catesbeiana}

Family Ranidae

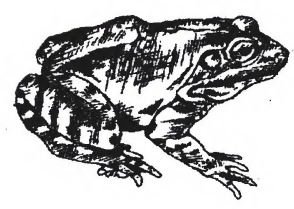

Global Rank: G5

State Rank: S5 (WY); SE (CA, CO, ID, NV, OR, UT, WA);

SE3 (MT); SE5 (AZ, NM)

Distribution: Native to most of North America east of the Rocky Mountains. The bullfrog has been introduced and established in western North America from southern British Columbia to northern Mexico. It ranges from near sea level to around $9,000 \mathrm{ft}$. $(2,740 \mathrm{~m}$.).

Description: Adults reach up to $7.9 \mathrm{in}$. (20 $\mathrm{cm}$.) in snout-vent length. Key characteristics include large body; a short fold extends from the eyes over and behind a conspicuous ear drum or tympanum; a pale green to dark olive dorsal coloration, often with spots (without white-borders of leopard frogs) or dark motthing; belly is cream to yellow, sometimes with dark marbling. Legs may be banded and blotched with dusky colors. There are no dorsolateral folds. Young individuals may be as large as adults of other frog species. Tad-

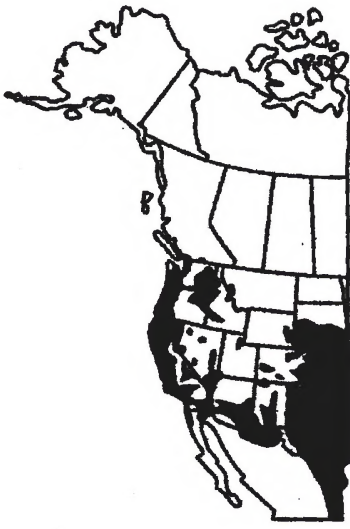

poles reach up to $6 \mathrm{in}$. $(15 \mathrm{~cm}$.) with key characteristics of the back and tail olive to greenish yellow with small black spots; belly is light colored. Adult males develop a yellow
Current range of the bullfrog 
throat, a swollen and darkened thumb base, and the eardrums become larger than the eyes. The voice is a deep-pitched bellow suggesting jug-o-rum or br-wum. The vocal sac is single and internal.

Reproduction: The bullfrog breeds in lakes and large ponds with a breeding season from February to August. Up to 20,000 eggs per clutch are laid, spread out in a thin sheet over 12 in. $(30 \mathrm{~cm}$ ) in diameter. Eggs sink onto submerged vegetation before hatching. Tadpoles may overwinter before transforming to the adult form.

Food: Adults are voracious carnivores and eat a variety of animals, including earthworms, insects, crayfish, frogs and their larvae, snakes, turtles, birds, and small mammals. Tadpoles eat algae, other submerged aquatic vegetation, and some animal matter.

Habits: Bullfrogs live in marshes, wet meadows, vegetated irrigation canals, ponds, and reservoirs. They prefer quiet or slowly flowing waters, and avoid areas without cover. Adults are wary, good jumpers, and difficult to catch. They may "play possum" and quickly recover and jump with loud squacks or miaows. They can be more easily captured at night using spotlights to detect reflections from their eyes.

Management Implications: The bullfrog is the only amphibian exploited extensively for food in the United States, and harvest is regulated. It has been introduced in many locations in the American West. Such introductions have been harmful to native frog populations since the bullfrog preys heavily on other frogs. The extinction of the northern leopard frog from at least one location in Washington is believed to be due to predation by bullfrogs.

Important References: Stebbins, R.C. 1985. A field guide to western reptiles and amphibi- ans. The Peterson Field Guide Series, Houghton Mifflin Company, New York, NY; Baxter, G.T., and M.D. Stone. 1980. Amphibians and reptiles of Wyoming. Wyoming Game and Fish Department, Cheyenne, WY; Csuti, B., A.J. Kimerling, T.A. O'Neil, M.M. Shaughnessy, E.P. Gaines, and M.M.P. Huso. 1997. Atlas of Oregon wildlife. Oregon State University Press, Corvallis, OR. 


\title{
California Newt
}

\author{
Taricha torosa
}

Family Salamandridae

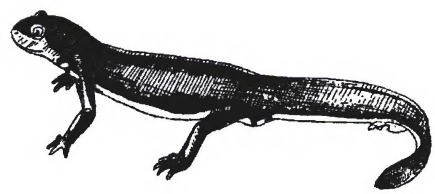

Global Rank: G5

State Rank: S4 (CA)

Distribution: Coast ranges of California from Mendocino County to the western slope of the Peninsular Ranges in San Diego County and western slope of Sierra Nevada south to Breckenridge Creek and Mill Creek in Kern County. Isolated population at Squaw Creek in Shasta County. Ranges from near sea level to about $6,500 \mathrm{ft} .(2,000 \mathrm{~m}$.). Found in all successional stages from blue oak savannah to mixed-conifer types. Prefers deciduous riparian habitats.

Description: Adults reach up to 3.5 in. (8.7 $\mathrm{cm}$.) in snout-vent length. They are similar to the rough-skinned newt except are usually lighter brown above and with less contrast between dorsal and ventral colors on the sides. Lower eyelids are light-colored, eyes are large, and corneal surfaces extend to or beyond the

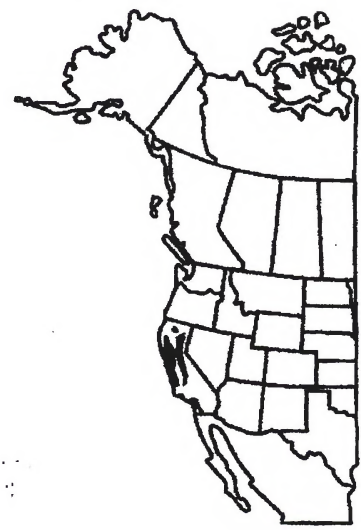
outline of the head when viewed from above. Teeth in the roof of the mouth usually in a Yshaped arrangement. Breeding males have smooth skin, bulbous vent, a flattened tail, and dark skin on underside of feet. 
Reproduction: The newt moves to pools in streams (and some ponds and lakes) during the first rains in the fall. They breed from December to May, with a peak in activity from February to April. Eggs are laid in clumps attached to submerged vegetation and the undersides of boulders.

Food: Searches for insects under surface objects and in streams.

Habits: Home ranges estimated at about 1 ac. ( 0.4 ha.), not inchuding movement to and from breeding sites. Found in all successional stages from blue oak savannah to mixed-conifer types, but prefers riparian deciduous vegetation.

Management Implications: Common in preferred habitat. No known management concerns. Wartiness is apparently caused by disease, and is more extreme in the southern part of the range.

Important References: Stebbins, R.C. 1985. A field guide to western reptiles and amphibians. The Peterson Field Guide Series, Houghton Mifflin Company, New York, NY; Verner, J., and A.S. Boss. 1980. California wildlife and their habitats: Western Sierra Nevada. USDA Pacific Southwest Forest and Range Experiment Station, GTR PSW-37, Berkeley, CA. 


\title{
California Slender Salamander
}

\author{
Batrachoseps attenuatus \\ Family Plethodontidae
}

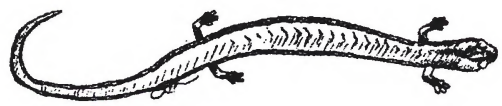

Global Rank: G5

State Rank: S2 (OR); S5 (CA)

Distribution: In coastal area from extreme southwestern Oregon (near mouth of Rogue River) to vicinity of San Benito River, the Sierran foothills from Big Chico Creek to the American River drainage. There are scattered populations in the Sacramento Valley and isolated populations in Shasta County, California. They range from sea level to $4,000 \mathrm{ft}$. $(1,220 \mathrm{~m}$.) in elevation.

Description: Adults reach nearly 2 in. (4.7 $\mathrm{cm}$.) in snout-vent length. Total length is $11 / 2$ to 2 times the snout-vent length. The head is narrow, the body and tail long, and limbs very short. The belly is black or dusky, usually arranged in a fine unbroken network. The undersides of the tail are often lighter than belly and tinged with yellow. Ventral surfaces including the midline of the tail and finely speckled with white. A dorsal stripe is often present and is brick-red, buff, or yellow. The remaining dorsal color is sooty to black. There are 18-20 costal grooves and 10-12 costal folds between adpressed limbs. Males have a more pointed lower jaw and a broader and

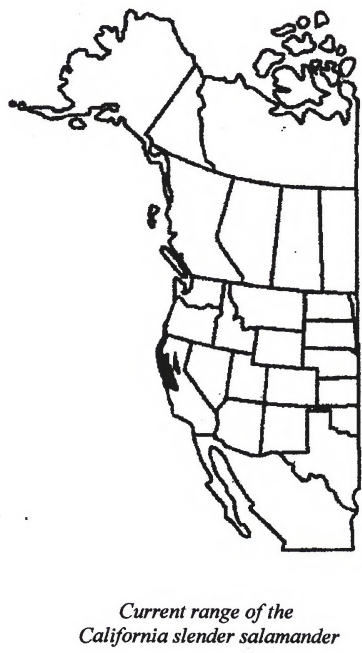
more squared off snout than females. 
Reproduction: Breeds from October to January, with peak breeding in November. Eggs are laid in moist places under surface objects and in burrows during the late fall and winter, often in communal nests. Young emerge in winter and spring.

Food: Feeds on small insects and other invertebrates searched for under surface objects.

Habits: Found in all successional stages of blue oak savannah, digger pine-oak and chaparral types. It prefers the blue oak savannah with scattered trees. It is the only slender salamander found in oak woodland north of the Merced River. Found under logs, boards, bark, and in damp leaf litter and rotting logs from the time of the first rains until the beginning of the dry period in late spring or summer.

Management Implications: Common in preferred habitat.

Important References: Stebbins, R.C. 1985. A field guide to western reptiles and amphibians. The Peterson Field Guide Series. Houghton Mifflin Company, New York, NY; Verner, J., and A.S. Boss. 1980. California wildlife and their habitats: western Sierra Nevada. USDA Pacific Southwest Forest and Range Experiment Station GTR PSW-37, Berkeley, CA. 


\section{Canadian Toad}

\section{Bufo hemiophrys \\ Family Bufonidae}

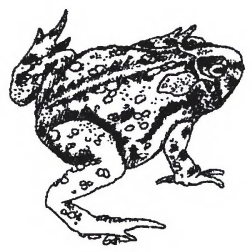

FWS Status: Endangered (WY)

Global Rank: G4

State Rank: S1 (MT, WY)

Distribution: The principal range of the species is most of Alberta and Saskatchewan south and east to northern Montana, North Dakota, southern Manitoba, and northwestern Minnesota. In Wyoming, the subspecies $B . h$. baxteri, known as the Wyoming toad, is a relict population known only from the Laramie Basin in Albany County. They are found from around 1,000 to $7,000 \mathrm{ft}$. ( 300 to $2,130 \mathrm{~m}$.) in elevation in prairies and aspen parkland, usually in or near water.

Description: The adult toads are relatively small, from 1.5 to $3 \mathrm{in}$. ( 3.7 to $7.5 \mathrm{~cm}$.) in snout-vent length. Coloration is generally brownish, greenish, or light gray, with small dark blotches and a sometimes indistinct white median line. There is a parallel-sided, fused cranial crest or boss on the head, paratoid

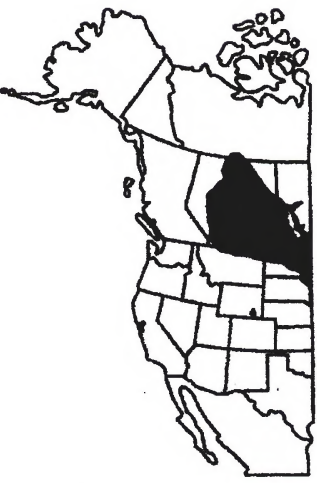
glands, and round pupils. The belly is spotted and adult males have dark throats. Cranial crests may not be fused into a boss in younger toads. Tadpoles are black or nearly so above 
and slightly lighter below and have a clear area on the throat and chest. Tail musculature is dark except for narrow light ventral area. The voice is a clear, soft trill or buzz of about $\mathbf{8 0}$ individual trills uttered about twice each minute, and adults have a round vocal sac.

Reproduction: Small breeding populations appear at ponds in May after daytime maximum temperatures reach near $70^{\circ} \mathrm{F}$. Eggs are laid in gelatinous strings from mid-May to July. Larvae usually transform by early August.

Food: The diet of adults includes ants, beetles, and a variety of arthropods.

Habits: The toad is a burrowing animal which probably requires some deep soil in which to burrow. In parts of its range, the Canadian toad uses Mina-type mounds to hibernate. It frequents lakes, ponds, streams, marshes, potholes, and roadside ditches, where it usually breeds in the shallows. It may swim well out from shore when frightened. The toads are mainly diurnal during the breeding season, retiring to sandy or loamy areas to bury themselves at night. Adults are active from late March to September during the days and nocturnal during warm nights.

Management Implications: The population of the endangered Wyoming toad is rare and probably near extinction. Possible causes for recent declines are widespread spraying of insecticides to control mosquitoes, changes in agricultural practices, increased predation, disease, and climatic changes.

Important References: Stebbins, R.C. 1985. A field guide to western reptiles and amphibians. The Peterson Field Guide Series, Houghton Mifflin Company, New York, NY; Baxter, G.T., and M.D. Stone. 1980. Amphibians and reptiles of Wyoming. Wyoming Game and Fish Department, Cheyenne, WY. 


\section{Canyon Treefrog}

Hyla arenicolor

Family Hylidae

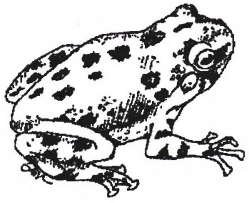

Global Rank: G5

State Rank: S2 (CO); S3 (UT); S4 (NM); S5 (AZ)

Distribution: The canyon treefrog occurs from southern Utah and extreme western Colorado to Oaxaca, Mexico, and in all but extreme western Arizona, and in western New Mexico. Disjunct populations are found in Davis and Chisos Mountains of west Texas. Exists from near sea level to around $9,800 \mathrm{ft}$. $(2,990 \mathrm{~m}$ ) in elevation.

Description: Adults reach $21 / 4 \mathrm{in}$. $(5.6 \mathrm{~cm}$ ) in snout-vent length. This brown, cream, or olive-gray treefrog usually has no eyestripe. Often blotched or spotted with dark brown or olive, cream below, and grading to yellow on hind legs. Coloration can quickly change to match background. The throat of adult males is dusky. Vocal sacs are weakly bilobed and the voice is an explosive $b a-a-a$ sounding like a hoarse lamb, goat, or duck.

Reproduction: Breeds from April through July or later, usually in rock-bound pools in canyon bottoms. Loose clusters of eggs are attached to rushes in shallow water. Tadpoles

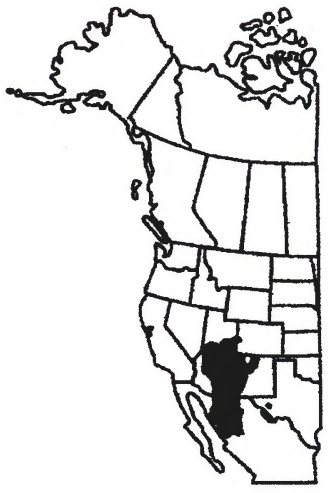

Current range of the canyon treefrog 
metamorphosed from late August to midOctober.

Food: Food habits are largely unknown. It is believed that they feed on a variety of invertebrates, inchuding beetles, true bugs, caddisflies, ants, caterpillars, and annelid worms.

Habits: The canyon treefrog is closely associated with areas of large boulders and rock outcrops along wooded canyon streams. They may be observed clinging to boulders a short distance above water, and appear to "sun" for long periods, periodically returning to water to rehydrate. Individuals have been found at least a kilometer from permanent water sources. May frequent arroyos in semi-arid grassland, streams in pinon-juniper and pine-oak woodlands, and tropical scrub forests (in Mexico).

Management Implications: Common within preferred habitat of rocky riparian zones.

Important References: Stebbins, R.C. 1985. A field guide to western reptiles and amphibians. The Peterson Field Guide Series, Houghton Mifflin Company, New York, NY; Degenhardt, W.G., C.H. Painter, and A.H. Price. 1996. The amphibians and reptiles of New Mexico. University of New Mexico Press, Albuquerque, NM. 


\section{Cascades Frog}

\section{Rana cascadae}

Family Ranidae

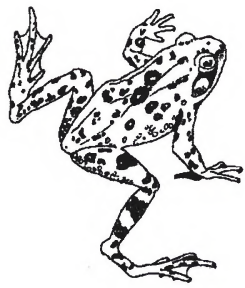

Global Rank: G4

State Rank: S3 (CA, OR); S4 (WA)

Distribution: In Cascade Mountains from northern Washington to vicinity of Lassen Peak, California. Isolated populations in Olympic Mountains, Washington; Mount Shasta and Lassen Peak areas, and Trinity Mountains, California. Ranges from about 1,000 to 9,000 ft. (305 to $2,740 \mathrm{~m}$ ) in elevation. It rarely occurs below $2,600 \mathrm{ft}$. $(800 \mathrm{~m}$.) except in California.

Description: Adult Cascades frogs reach up to $3 \mathrm{in}$. $(7.5 \mathrm{~cm}$.) in snout-vent length. They are brown to olive-brown above, with welldefined inky black spots on the back and dark spotting on legs. Black flecks between the spots are scarce or absent. The lower abdomen and undersides of hind legs are yellow, orangeyellow, or yellowish tan. The groin is usually bright yellow with dark molting, and lower sides are yellowish or cream. Dorsolateral folds are present. Adult males have swollen and darkened thumb bases. The voice is a high-pitched grating, chuckling sound, and

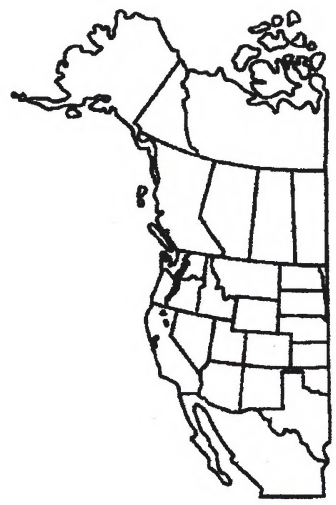
may be given either above or below water. 
Reproduction: The Cascades frogs breed early, as soon as water becomes free of ice and snow. Eggs are laid from March to June with females laying about 300 eggs (range 100600 ). Tadpoles form schools over their twomonth larval period, and metamorphose in August and September. Some may overwinter as larvae. Sexual maturity is reached after three years.

Food: Adults feed on a variety of insects and other small invertebrates. Larvae eat algae and other organic matter.

Habits: Closely associated with water, this species occurs in lakes, ponds, and small streams that run through meadows. Preferred habitat is open coniferous forests with mountain meadows, riparian deciduous, and alpine meadows. It is a rather sluggish, often allowing close approach. When frightened, it usually attempts to escape by swimming rather than hiding. It is not known to be territorial. The size of home ranges is unknown.

Management Implications: Although their distribution was always discontinuous, they were formally very abundant in some locations. One report of 30 locations (WA, OR) studied since the 1970 s found that 80 percent had disappeared by 1990 .

Important References: Stebbins, R.C. 1985. A field guide to western reptiles and amphibians. The Peterson Field Guide Series, Houghton Mifflin Company, New York, NY; Csuti, B., A.J. Kimmerling, T.A. O'Neil, M.M. Shaughnessy, E.P. Gaines, and M.M.P. Huso. 1997. Atlas of Oregon wildlife. Oregon State University Press, Corvallis, OR; Verner, J., and A.S. Boss. 1980. California wildlife and their habitats: Western Sierra Nevada. USDA Pacific Southwest Forest and Range Experiment Station, GTR PSW-37, Berkeley, CA. 


\title{
Chiricahua Leopard Frog
}

\author{
Rana chiricahuensis
}

Family Ranidae

FWS Status: PT

Global Rank: G3

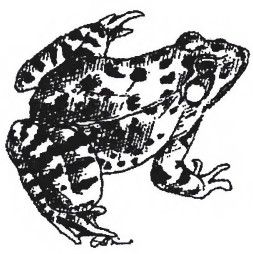

State Rank: S1 (NM); S3 (AZ)

Distribution: Occurs in mountain regions of central and southeastern Arizona, southwestern New Mexico, and the Sierra Madre Occidental, to southern Durango in Mexico (Sonora and Chihuahua). There appears to be a gap in range along the lower Gila River in Arizona, and isolated populations in Socorro County, New Mexico. The species ranges from around 3,500 to $7,900 \mathrm{ft}$. (1,070 to 2,410 $\mathrm{m}$.) in elevation.

Description: Adult frogs reach up to $51 / 2$ in. $(13.5 \mathrm{~cm}$.) in snout-vent length. They are stockier than the northern leopard frog and have a more rounded head, shorter limbs, and slightly upturned eyes. The dorsolateral folds usually are broken into short segments towards the rear and angled inward. The skin is rougher, with more tubercles. Dorsal spots are generally smaller and more numerous than with other leopard frogs. Coloration above is generally greenish or brown, and face is usually green. The upper lip stripe is diffused or absent in front of the eyes. The rear of the

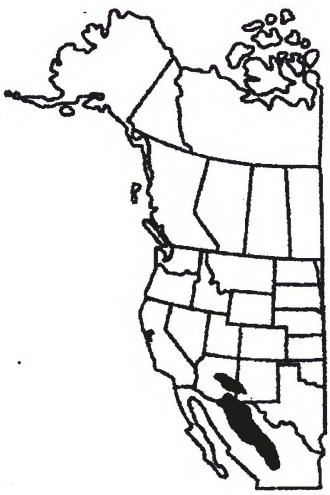
thighs are speckled with "salt-and-pepper"

Current range of the Chiricahua leopard frog 
patterns, with each small dot having a tubercle. Coloration below is dull whitish or yellowish, with gray mottling on throat and yellowish on groin and lower abdomen. Adult males have swollen and darkened thumb base. The call is long and snorelike, and appears to be more rapid than most leopard frogs.

Reproduction: In thermally stable habitats, the frog may remain reproductively active throughout the year, with tadpoles growing continuously during the winter months. Where water temperatures are variable, reproduction has been noted only from late-February through May and from mid-August through late September. Metamorphose may occur in a little as 2-3 months at relatively stable water temperatures and up to 8-9 months in habitats having drops in winter water temperatures.

Food: Food habits of the Chiricahua leopard frog have not been well studied, but are believed to be similar to all leopard frogs. They probably eat a variety of insects and other arthropods.

Habits: The frog is highly aquatic and is found chiefly in oak and mixed oak and pine woodlands and in pine forests where it frequents rocky streams with deep rock-bound pools. It may also range into areas of chaparral, grasslands, and even desert. It is known to be attracted to river overflow pools, oxbows, permanent springs (including thermal pools), ponds, and earthen stock tanks.

Management Implications: The Chiricahua leopard frog has been in decline throughout its range in both Arizona and New Mexico. The FWS did a status review of the species in 1994 and has proposed it for threatened status.
Important References: Stebbins, R.C. 1985. A field guide to western reptiles and amphibians. The Peterson Field Guide Series, Houghton Mifflin Company, New York, NY; Degenhardt, W.G., C.W. Painter, and A.H. Price. 1996. Amphibians and reptiles of New Mexico. University of New Mexico Press, Albuquerque, NM. 


\title{
Clouded Salamander
}

\author{
Aneides ferreus \\ Family Plethodontidae
}

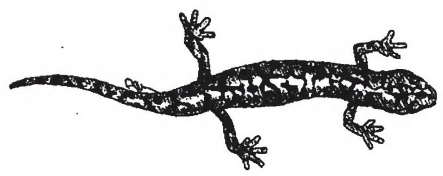

Global Rank: G3

State Rank: S2 (CA); S4 (OR)

Distribution: Ranges from extreme southwestern Washington, Coastal and Cascade Mountains of Oregon and California. Also occurs on Vancouver Island in British Columbia, Canada, but may have been introduced there. Extends from sea level to about 5,400 $\mathrm{ft} .(1,650 \mathrm{~m}$.) in elevation.

Description: Adults reach up to $5 \mathrm{in} .(13 \mathrm{~cm}$.) in total length. As with all Plethodontidae lungless salamanders, there is no free-living larvae stage. Young emerge fully formed. They are slim, long-legged, agile, and excellent climbers. Toes have slightly broadened and squarish tips. There are usually 16 costal grooves. Coloration varies from brown, clouded with ash, greenish gray, pale gold, or reddish above, and dusky below. Recently hatched young have a copper or brassy dorsal stripe which soon is reduced to patches on the snout, shoulders, and tail, and stripes on the upper surface of the base of limbs. Mature males have a heart-shaped mental gland that is absent in females.

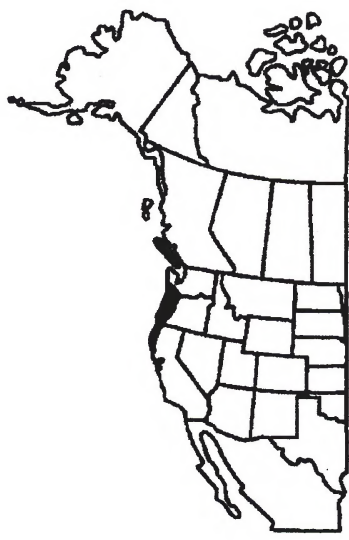

Current range of the clouded salamander 
Reproduction: Eggs are laid from spring to early summer and hatch in September and October. Clutch size averages 14 eggs (range 8-18) and eggs are brooded, usually by the females, until they hatch. The incubation period is about two months. Females breed in alternate years.

Food: Clouded salamanders eat small invertebrates, including ants, beetles, mites, spiders, and springtails. In one study in Oregon, 57 percent of the diet was comprised of ants.

Habits: The clouded salamander is primarily a forest dweller, found in moist areas under loose bark of standing or fallen dead trees and other debris. It may be common at the edges and within clearings caused by fire or timber harvest if large downed logs are present. It may climb trees to at least $20 \mathrm{ft}$. $(6 \mathrm{~m}$.). It becomes inactive in cold weather. Colonies may be found deep inside downed logs, especially during the summer.

Management Implications: Populations of this salamander can adapt to timber harvest practices that leave downed logs scattered in clearings, but not to young reforested areas lacking coarse woody debris.

Important References: Stebbins, R.C. 1985. A field guide to western reptiles and amphibians. The Peterson Field Guide Series, Houghton Mifflin Company, New York, NY; Csuti, B., A.J. Kimerling, T.A. O'Neil, M.M. Shaughnessy, E.P. Gaines, and M.M.P. Huso. 1997. Atlas of Oregon wildlife. Oregon State University Press, Corvallis, OR. 


\title{
Coeur d'Alene Salamander
}

\author{
Plethodon idahoensis
}

Family Plethodontidae

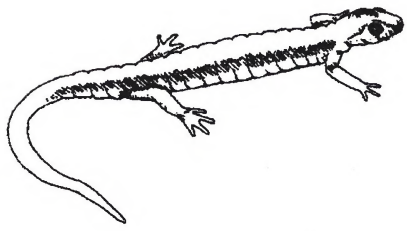

BLM Status: Sensitive (ID)

Global Rank: G3

State Rank: S2 (MT); S3 (ID)

Distribution: Formerly considered to be a subspecies of the Van Dyke salamander (Plethodon vandykei), the species ranges from northern Idaho to extreme northwestern Monana. There are three known locations in British Columbia, all along the southeastern corner of Kootenay Lake. The salamander extends from approximately $2,000 \mathrm{ft}$. (700 m.) to over 5,000 ft. $(1,550 \mathrm{~m}$. $)$ in elevation.

Description: Adult Coeur d'Alene salamanders reach up to $4 \mathrm{in}$. $(10 \mathrm{~cm}$.) in total length. They are lungless and breathe through their thin, moist skin. They have hairline furrows extending from each nostril to the edge of the upper lip, and well-defined costal groves along sides. There are no free-living larvae with the young emerging fully formed. Adult coloration has a dorsal stripe of yellow, green, orange, or red with uneven edges, and there is a yellow patch on the throat. The fourth toes on the hindfeet are shorter. Juveniles have a conspic-

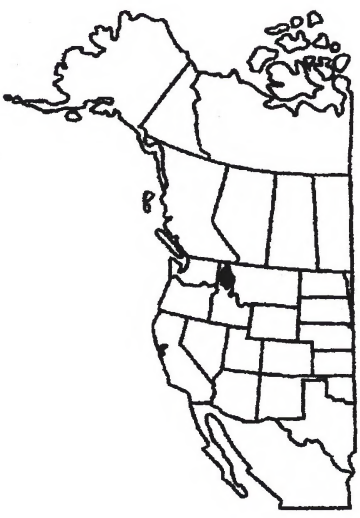

Current range of the Coeur d'Alene salamander 
uous yellow dorsal stripe, black sides and belly, and yellow throat patch.

Reproduction: Mating occurs in late summer and fall, and occasionally in the spring. Females can store sperm up to nine months before fertilizing eggs. An average of six eggs are laid on land in moist concealed places in April-May. Young emerge in September. Adults first breed in their fourth or fith years, and females may have biennial reproductive cycles.

Food: Coeurd'Alene salamanders feed primarily on insects and other invertebrates, generally restricting foraging activities to moist spray areas, seeps, or streamside rocks and vegetation.

Habits: Generally found in three major types of habitat: springs or seepages, spray zones of waterfalls, and edges of streams. Habitat is often associated with fractured rock. The salamanders may spend as much as seven months a year underground in cool, moist interstitial spaces between rocks to avoid desiccation in summer and freezing in winter. Activity above ground in the summer is usually nocturnal during moist weather. In northern Idaho, they emerge from winter hibernation in late March and are active near the surface through April and May.

Management Implication: The Coeur d'Alene salamanders are typically aquatic and restricted in movements over terrestrial habitats. Populations are often small and apparently isolated, and a concern exists for their continued viability. Protection of springs and seeps, spray areas at waterfalls, and edges of streams appears important. The widening and improvement of highways along streams may be an important management concern.
Important References: Stebbins, R.C. 1985. A field guide to western reptiles and amphibians. The Peterson Field Guide Series, Houghton Mifflin Company, New York, NY; Cassirer, F., C. Johnson, D. David, and C. Peterson. 1994. The Coeur d'Alene salamander (Plethodon idahoensis) in Idaho. Idaho State Conservation Effort, Idaho Department of Fish and Game, Boise, ID; Groves, C.R., B. Butterfield, A. Lippincott, B. Csuti, and J.M. Scott. 1997. Atlas of Idaho's wildlife. Idaho Department of Fish and Game, Boise, ID. 


\section{Columbia Spotted Frog}

\section{Rana luteiventris}

Family Ranidae

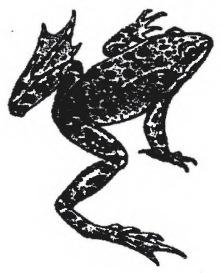

FWS Status: Candidate

BLM Status: Sensitive (AK, ID, MT, NV, OR, UT, WA)

Global Rank: G4

State Rank: S1 (UT); S2 (AK, OR);

S2S3 (NV, WY); S3S4 (ID, WA); S4 (MT)

Distribution: Prior to 1996, the spotted frog was considered to be one species (Rana pretios $a$ ) and the Great Basin population, a subspecies ( $R$. p . luteiventris). Now considered two distinct species, the Oregon spotted frog ( $R$. pretiosa) extends from the Cascade Mountains to the Pacific Coast in Oregon, and the Columbia spotted frog ( $R$. luteiventris) from central Oregon to the East. Species accounts are similar for both species until range maps and characteristics of each species are more fully developed. The overall range of the spotted frog extends from southeastern Alaska south through most of British Columbia and the western edge of Alberta; most of Idaho, Washington, and Oregon; western Montana; northwestern Wyoming; and isolated populations in higher elevations of northern

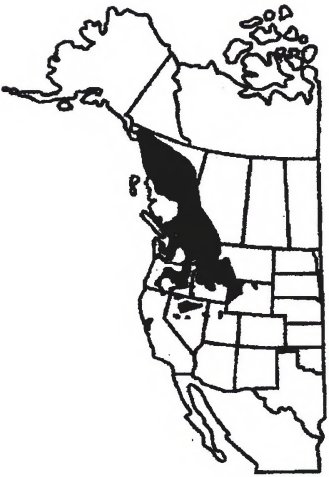

Current range of the Columbia spotted frog 
Nevada and Utah. They occur from near sea level to about $10,000 \mathrm{ft}$. $(3,050 \mathrm{~m}$.) in elevation.

Description: Adult spotted frogs are about 3.5 in. $(9 \mathrm{~cm}$.) in snout-vent length. Key characteristics include dorsal black spots with "fuzzy" edges; white lip stripe; full webbing between hind toes; somewhat bumpy skin; pointed snout; and upturned eyes. Adult spotted frogs have yellow or red coloration on the underside of legs and belly; however, this coloration is usually lacking in juveniles. The voice is a series (4 to 50) of faint, rapid, lowpitched clicks, lasting up to about 10 seconds. The call may be given above and occasionally under water.

Reproduction: Frogs at lower elevations reach maturity at about two years of age, breed earlier in the year and on a yearly basis, and live about five years. At higher elevations, they mature more slowly, do not breed every year, and live longer. Breeding occurs from February in lower elevations to July in mountain locations. Eggs are laid in softball-sized clutches up to 2,400 eggs. Egg masses float on the surface and many females may deposit their eggs at the same site. Recently hatched tadpoles are black. As they grow, they become brownish green, flecked with gold, have medially located eyes, and the intestines are visible. Tadpoles may become as large as 3 in. $(8 \mathrm{~cm}$.) before metamorphosing. Most tadpoles metamorphose their first year, except some may overwinter as larvae at high elevations.

Food: Adults eat a wide variety of insects, mollusks, and arachnids. Larvae eat algae, organic debris, plant tissue, and minute waterborne organisms.

Habits: Spotted frogs are closely associated with water, being dependent on streams, rivers, marshes, springs, pools, and small lakes for overwintering, breeding, and foraging habitat. After breeding, they may move overland a considerable distance from water. Breeding areas are mostly shallow, standing water, springs, or slow moving and backwater portions of rivers and streams. For overwintering in cooler portions of their range, they may congregate in areas where the water does not freeze. Preferred habitat is usually areas with thick algae and emergent vegetation, but may use sunken, dead, or decaying vegetation as escape cover.

Management Implication: The introduced bullfrogs are a major threat to all stages of spotted frogs. Other threats include loss and fragmentation of habitat through factors such as livestock impacts (vegetation removal, trampling, changes in water quality), drought, water diversions, contaminants, and various kinds of developments. Importance of factors such as increased ultraviolet radiation, parasites, or other factors which may be causing world-wide declines in amphibians are still unknown.

Important References: Stebbins, R.C. 1985. A field guide to western reptiles and amphibians. The Peterson Field Guide Series; Houghton Mifflin Company, New York, NY; Csuti, B., A.J. Kimerling, T.A. O'Neil, M.M. Shaughnessy, E.P. Gaines, and M.M.P. Huso. 1997. Atlas of Oregon wildlife. Oregon State University Press, Corvallis, OR; Groves, C.R, B. Butterfield, A. Lippincott, B. Csuti, and J.M. Scott. 1997. Atlas of Idaho's wildlife. Idaho Department of Fish and Game, Boise, ID. 


\title{
Cope's Giant Salamander
}

\author{
Dicamptodon copei \\ Family Dicamptodontidae
}

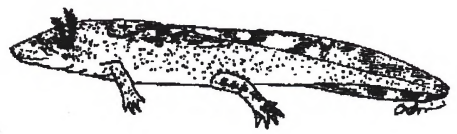

Global Rank: G3

State Rank: S2 (OR); S3 (WA)

Distribution: Ranges from the Olympic Peninsula in Washington south through the southern Cascades and Willapa Hills to streams draining into the Columbia River, and in extreme northwestern Oregon. Extends from near sea level to around $4,500 \mathrm{ft} .(1,370 \mathrm{~m}$.) in elevation.

Description: The larval form reaches to 8 in. $(20 \mathrm{~cm}$ ) in total length. The larvae rarely transform into the adult stage. It resembles the larvae of the Pacific giant salamander, but is slimmer and does not reach such a large size. The head is smaller and narrower, the tail fins are lower and shorter, and the dorsal fin usually does not reach to the area above the vent. Fins have less dark mottling, the eyestripe is faint or missing, and the belly is darker. A transformed individual from Spirit Lake, Washington, was sooty with no pattern above and dark gray below.

Reproduction: Little is known and life history

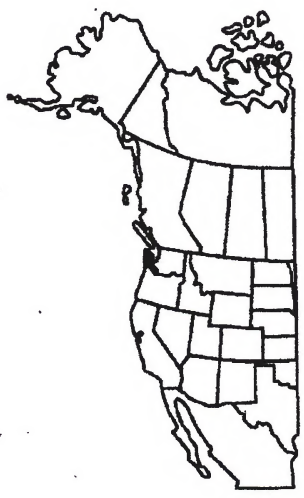
is inferred from the Pacific giant salamander. It

Current range of the Cope's giant salamander 
probably breeds as neotenic larvae from spring to fall, laying a clutch of 20-115 eggs in nest chambers under stones. Females guard the eggs from predators. It may take as long as nine months until eggs are hatched.

Food: This salamander feeds on a wide variety of aquatic organisms, including insect larvae, fish eggs, tadpoles, and young salmonids and sculpins.

Habits: Cope's giant salamanders are found in moist coniferous forest areas in clear, cold streams where the temperature is usually between $8^{\circ}$ and $14^{\circ} \mathrm{C}$., and in mountain lakes and ponds with gravel bottoms and boulders. They may be found on wet rocks and vegetation on rainy nights, but usually occur under rocks, slabs of bark, or other cover in streams.

Management Implications: The species was first described in 1970. Terrestrial adults are very rare with only three metamorphosed adults being known through 1997 . Its requirements for clear, cold water may make it sensitive to logging activities. The type locality was near Mount St. Helens, and that population may have been destroyed by eruptions of the mountain.

Important References: Stebbins, R.C. 1985. A field guide to western reptiles and amphibians. The Peterson Field Guide Series, Houghton Mifflin Company, New York, NY; Csuti, B., A.J. Kimerling, T.A. O'Neil, M.M. Shaughnessy, E.P. Gaines, and M.M.P. Huso. 1997. Atlas of Oregon wildlife. Oregon State University Press, Corvallis, OR. 


\title{
Couch's Spadefoot
}

\author{
Scaphiopus couchii \\ Family Pelobatidae
}

Global Rank: G5

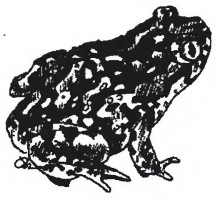

State Rank: S1 (C0); S3 (CA); S5 (AZ, NM)

Distribution: Ranges from southwestern Oklahoma, central New Mexico, and southcentral Arizona to the tip of Baja California, southeastern California, and central Texas. Isolated populations are in the vicinity of the Petrified Forest National Monument in Arizona and in Otero County, Colorado. It extends from near sea level to around $5,600 \mathrm{ft}$. $(1,710 \mathrm{~m}$. $)$ in elevation.

Description: Adults reach up to $31 / 2$ in. (8.7 $\mathrm{cm}$ ) in snout-vent length. A large greenish, greenish-yellow, or brownish yellow spadefoot, with an irregular network, blotches, or flecks of black, brown, or dark green. The belly is whitish. The eyes are widely separated with the width of the eyelids about the same as or less than the distance between them. No boss exists between the eyes, and there is no pug-dog profile. Spade on the hind feet is black and sickle-shaped. Males are often more greenish than females, dark marking above is usually subdued or absent, and throats are pale. The voice is a plaintive cry or groan, declining in pitch, like an anxious bleat of a

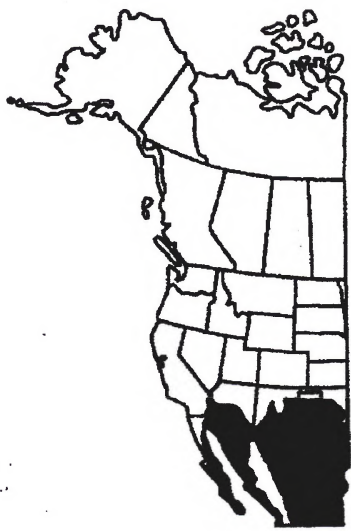

Current range of the Couch's spadefoot sheep. 
Reproduction: Breeding activity usually occurs during summer rains in temporary rainfilled depressions. Up to 90 percent of the breeding occurs on the first night following pond formation. Breeding is non-random with larger males mating more often. Eggs numbers vary, but average about 3,300 eggs. Eggs hatch in as little as 15 hours, depending upon water temperature. Tadpoles have the most rapid rate of development of any North American anuran, and metamorphose at approximately $15-20 \mathrm{~mm}$. in snout-vent length.

Food: Couch's spadefoot is a generalized arthropod predator, concentrating mainly on ground-dwelling species. Over 80 percent of the diet is comprised of beetles, orthopterans, ants, spiders, and termites. Those arthropods with well-known chemical defenses, such as blister beetles, velvet ants, stink bugs, and millipedes, are usually not included in the diet. They may be able to consume enough food in one meal to last an entire year. Studies found that they may consume as much as 55 percent of their body weight in a single feeding of termites. The high energy content of termites and their simultaneous emergence with the Couch's spadefoot during the first summer rains, probably makes the presence of termites essential to the survival of spadefoot toads in the desert.

Habits: The Couch's spadefoot is probably the most xeric adapted of all North American anurans with reports of up to three years without sufficient rainfall to stimulate emergence. Habitat includes arid grasslands and areas of creosotebush and mesquite, where soils are sandy and well-drained. It occasionally is found in irrigated agricultural lands and may be abundant on desert highways after summer thunderstorms. The species is largely nocturnal and spends most of its life buried in the soil and emerges only during spring and summer rains.
Management Implications: Skin secretion while handling may be toxic to some humans. Pain may be experienced with scratched areas, and incessant sneezing and discharges from eyes and nostrils have been noted. Secretions from other spadefoot species may have the same results. The availability of termites may be important to the survival of the species.

Important References: Stebbins, R.C. 1985. A field guide to western reptiles and amphibians. The Peterson Field Guide Series, Houghton Mifflin Company, New York, NY; Degenhardt, W.G., C.W. Painter, and A.H. Price. 1996. Amphibians and reptiles of New Mexico. University of New Mexico Press, Albuquerque, NM. 


\title{
Del Norte Salamander
}

\author{
Plethodon elongatus
}

Family Plethodontidae

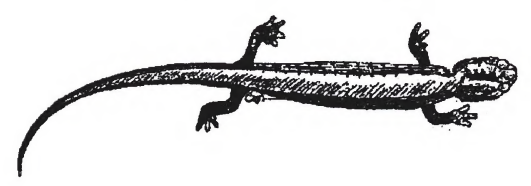

Global Rank: G3

State Rank: S2 (OR); S3 (CA)

Distribution: This species is found only in extreme southwestern Oregon (Curry and Coos Counties) and extreme northwestern California (Humboldt, Trinity, and Siskiyou Counties). Extends from near sea level to around $3,900 \mathrm{ft} .(1,200 \mathrm{~m}$.) in elevation.

Description: Adults reach 6 in. $(15 \mathrm{~cm}$.) in total length. They are a long-bodied, dark brown or black salamander, usually with 18 (occasionally 17-20) costal grooves, and short limbs. Toes are short and slightly webbed with coastal folds. The even-edged dorsal stripe is usually brown, reddish brown, or tan. Sides are sprinkled with white to light gray specks. The underside of the head has pale orangeyellow flecks. Young are sooty to nearly black above, or with a reddish brown or tan dorsal stripe. Adult males have a mental gland present.

Reproduction: Breeding probably occurs in the spring. Nests are in moist cavities in rock

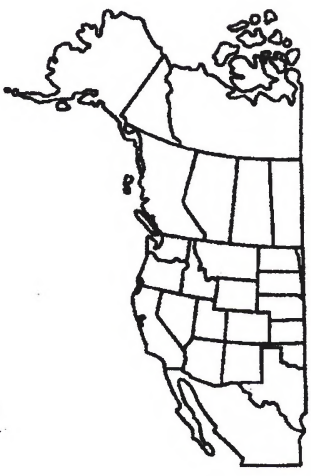
talus or under logs. About eight eggs are laid.

Current range of the Del Norte salamander 
They are tended by the females and hatch in the fall.

Food: It feeds on small invertebrates such as springtails, larval and adult beetles, some butterfly and moth larvae, leafhoppers, and millipedes.

Habits: Often found in rock rubble of old riverbeds, road fills, outcrops, and in mosscovered talus within humid coastal forests. It is occasionally found in decaying logs and under litter on the forest floor. Most common in old-growth Douglas-fir forests.

Management Implications: The species was previously a federal candidate species and state sensitive species in Oregon. It is possible that road construction which increases rock rubble may increase habitat for this species, as it retreats deep into rock crevices during hot, dry weather. Old growth forests may be important to its survival.

Important References: Stebbins, R.C. 1985. A field guide to western reptiles and amphibians. The Peterson Field Guide Series, Houghton Mifflin Company, New York, NY; Csuti, B., A.J. Kimerling, T.A. O'Neil, M.M. Shaughnessy, E.P. Gaines, and M.M.P. Huso. 1997. Atlas of Oregon wildlife. Oregon State University Press, Corvallis, OR. 


\title{
Dunn's Salamander
}

\author{
Plethodon dunni
}

Family Plethodontidae

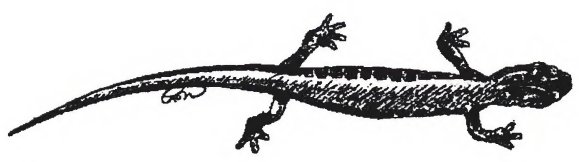

Global Rank: G4

State Rank: S2 (WA); S3 (CA); S4 (OR)

Distribution: Coastal and Cascade Mountains from southwestern Washington (Pacific County) to northwestern California (Del Norte County). Most of its range is in Oregon. Extends from near sea level to around $3,200 \mathrm{ft}$. $(1,000 \mathrm{~m}$.) in elevation.

Description: Adults reach about 6 in. $(15 \mathrm{~cm}$.) in total length. The dorsal stripe is tan, yellow, or greenish-yellow, brightening on the tail but not reaching the tip. The stripe may be heavily covered with dusky flecks. Sides are dark brown or black, spotted with yellowish or tan and speckled with white. Upper surface of base of limbs are yellow, dusky flecked. Lower surface is slaty with small spots of yellowish or orange. The tail is slightly flattened from side to side. It usually has 15 costal grooves. Adult males have a small lobe on each side of the rear edge of the vent.

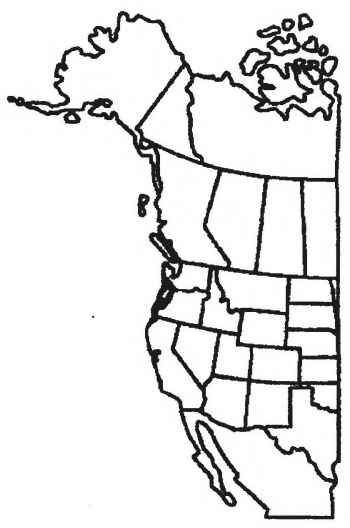

Current range of the Dunn salamander

Reproduction: Eggs are laid in the spring and hatch in the late summer or fall. The average 
clutch size is 13 eggs (range 3-18). Eggs are deposited in rock crevices and moist talus near permanent cold-water streams and seeps. The eggs are brooded by the female and hatch after an incubation period of about 70 days.

Food: Feeds on small invertebrates, including springtails, isopods, mites, flies, beetles, and worms. It occasionally is cannibalistic.

Habits: This species is found in and around streams and seeps in coniferous or mixed forests, often in the splash zone or under rocks, logs, moss, or leaf litter. It prefers moss-covered rock rubble and talus along permanent streams and seeps.

Management Implications: Relatively common in preferred habitats. No known threats.

Important References: Stebbins, R.C. 1985. A field guide to western reptiles and amphibians. The Peterson Field Guide Series, Houghton Mifflin Company, New York, NY; Csuti, B., A.J. Kimerling, T.A. O'Neil, M.M. Shaughnessy, E.P. Gaines, and M.M.P. Huso. 1997. Atlas of Oregon wildlife. Oregon State University Press, Corvallis, OR. 


\section{Ensatina}

\section{Ensatina eschscholtzii}

Family Plethodontidae

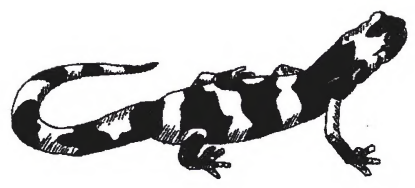

Global Rank: G5

State Rank: S2S3 (CA); S5 (OR, WA)

Distribution: Ranges from southwestern British Columbia, south along the Coastal, Cascade, and Sierra Nevada Mountains to the Transverse and Peninsular ranges of southern California and extreme northern Baja California. At least five subspecies known, most of which are in California. Extends from about sea level to around $8,000 \mathrm{ft}$. $(2,440 \mathrm{~m}$.) in elevation.

Description: Adults reach up to 4 in. $(10 \mathrm{~cm}$.) in total length. The ensatina is a smoothskinned salamander with 12-13 costal grooves and a swollen tail, constricted at the base. The defensive posture is characteristic; it stands stiff-legged and sway backed with its tail arched. Color varies greatly, but nearly all have yellow or orange limb bases. Adult males have an enlarged upper lip and the tail is longer and slimmer than in females.

Reproduction: Courtship and egg-laying can

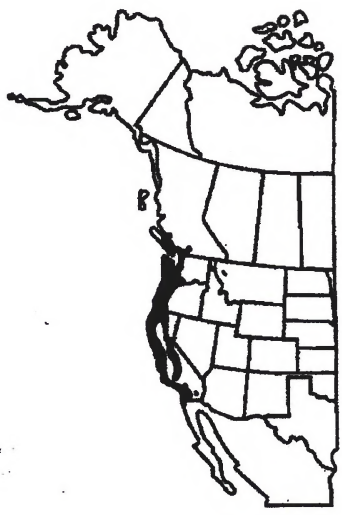
occur from fall through spring. Eggs are laid in Current range of the ensatina leaf litter, logs, or rodent burrows. The female 
broods the eggs until they hatch. Young emerge with the fall rains. The average clutch size is 11 eggs (range 5-16).

Food: Diet consists of small arthropods such as spiders, springtails, beetles, mites, termites, and ticks. Larger individuals will take earthworms and snails as well.

Habits: Ensatinas are found under logs, rocks, or other debris on forest and woodland floors. Although they require moist microhabitats, they are not associated with open water. Densities of up to three individuals per square meter have been observed near Portland, Oregon.

Management Implications: This species can be quite abundant in appropriate habitats. No known threats to survival of the species. As a defense against predators, the ensatina secretes a white, poisonous mucus along the top of the tail when disturbed. This is the only species in the genera.

Important References: Stebbins, R.C. 1985. A field guide to western reptiles and amphibians. The Peterson Field Guide Series, Houghton Mifflin Company, New York, NY; Csuti, B. A.J. Kimerling, T.A. O'Neil, M.M. Shaughnessy, E.P. Gaines, and M.M.P. Huso. 1997. Atlas of Oregon wildlife. Oregon State University Press, Corvallis, $O R$. 


\title{
Foothill Yellow-legged Frog
}

\author{
Rana boylii \\ Family Ranidae
}

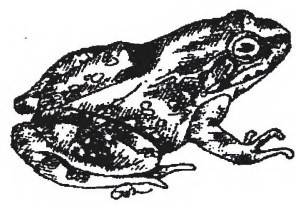

Global Rank: G3

State Rank: S2S3 (CA); S3 (OR)

Distribution: Range extends from the Coastal and Cascade Mountains in Oregon, south through the Coastal and Sierra Nevada Mountains of California to northern Los Angeles County. There are a few isolated populations in northern Baja California. Extends from near sea level to around $7,000 \mathrm{ft} .(2,130 \mathrm{~m}$.) in elevation.

Description: Adults reach up to 3 in. $(7 \mathrm{~cm}$.) in snout-vent length. Color varies from gray, brown, reddish, or olive above, sometimes plain-colored but more often spotted and mottled with dusky. Colors often blend with background. Yellow extends from the underside of the hind legs to the lower abdomen. The snout has a triangular, usually buff colored patch from the tip to a line connecting the eyelids, but without a mask. Throat and chest

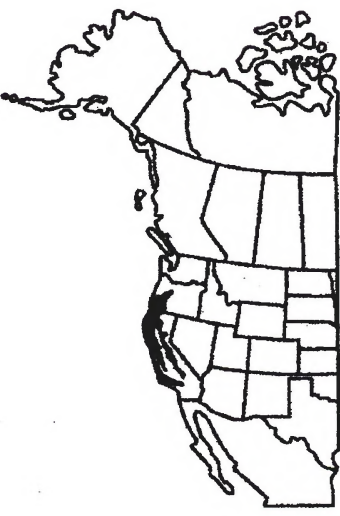
are often dark spotted. Young with faint or absent yellow coloration on hind legs. Adult males have swollen and darkened thumb bases.
Current range of the foothill yellow-legged frog 
Reproduction: The species breeds after high water subsides, usually from late April to early June. Females lay clutches of about 1,000 eggs, which hatch in about five days. Tadpoles metamorphose in three or four months.

Food: Adult frogs eat a variety of both aquatic and terrestrial invertebrates, including grasshoppers, hornets, ants, flies, beetles, and mosquitoes.

Habits: A stream or river frog of woodland, chaparral, and forest usually found near water, especially near riffles where there are rocks, stream-side vegetation, and sloping banks for sunning. Some streams in its range may dry to a series of potholes connected by trickles in the summer. Individuals have been found up to 50 meters from permanent water on moist outcrops. If startled when along streambanks they jump into the water and hide under rocks and vegetation. Garter snakes are a major predator of this species.

Management Implications: This frog was once considered common, but some populations have declined greatly. Present status and reasons for population declines are unknown. Reductions in flows from foothill streams may be a factor.

Important References: Stebbins, R.C. 1985. A field guide to western reptiles and amphibians. The Peterson Field Guide Series, Houghton Mifflin Company, New York, NY; Csuti, B., A.J. Kimerling, T.A. O'Neil, M.M. Shaughnessy, E.P. Gaines, and M.M.P. Huso. 1997. Atlas of Oregon wildlife. Oregon State University Press, Corvallis, OR. 


\section{Great Basin Spadefoot}

\section{Spea intermontana}

Family Pelobatidae

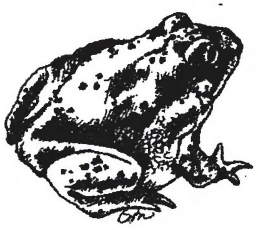

Global Rank: G5

State Rank: S2 (AZ); S3 (CO); S4 (ID, NV, UT, WY); S5 (CA, OR, WA); SR (MT)

Distribution: Formally classified under the genus Scalphiopus, the Great Basin spadefoot ranges from extreme southern British Columbia through the Great Basin to extreme northwestern Arizona, and from the eastern edge of the Cascade/Sierra Mountains east to the Rocky Mountains. It extends from sagebrush flats to spruce-fir belts around 9,200 ft. $(2,800$ m.) in elevation.

Description: Adults reach up to 2.5 in. (6.5 $\mathrm{cm}$.) in snout-vent length. Key characteristics are stocky body, vertical pupils, blunt snout, relatively smooth and dry skin, and a black, sharp-edged "spade" on the underside of each hind foot. Tadpoles reach up to 2.75 in. (7 $\mathrm{cm}$.) in total length with key characteristics of

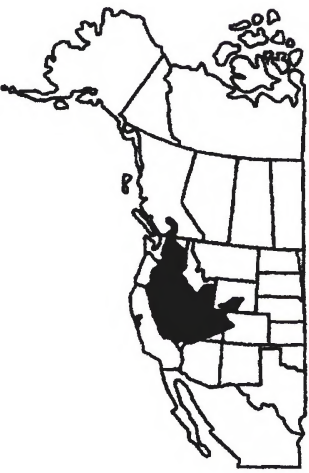
pale tan or gray coloration with brassy flecks, eyes close together and dorsally oriented, prominent nostrils, anteriorly positioned mouth with keratinized beak, and heavy body. The Current range of the Great Basin spadefoot voice of breeding adults is a series of short, 
rapid wa-wa-wa calls from a rounded, slightly bilobed vocal sac

Reproduction: Breeding occurs sporadically from April through July, usually after spring rains. Eggs are laid in grape- to plum-sized clusters of 20 to 40 eggs each, usually loosely attached to vegetation, floating sticks, or bottom mud and rocks. Total eggs per female may equal 300 to 500 , although up to 800 eggs are known. Eggs often hatch in 2-3 days and larval periods rarely last more than a few weeks as an adaptation to rapidly drying water sources.

Food: Adults are known to eat ants, beetles, grasshoppers, crickets, and flies. Larvae probably eat algae, organic debris, and plant tissue.

Habits: Great Basin spadefoot toads are active on the surface, especially at night. They dig burrows in loose soil or use burrows of small mammals to escape cold, hot, and dry weather. They both hibernate and aestivate. They use a variety of temporary and permanent waters for breeding. They are prey to a number of mammalian and avian predators and probably fishes. Adult spadefoots have noxious skin secretions known to repel predators and cause sneezing in humans.

Management Implications: The species may have expanded its range in some areas by using irrigation ditches. Recent conversions to sprinkler irrigation systems may have reversed that expansion. Also, conversion of sagebrush deserts to pastures or grain crops may have eliminated the toad from parts of its former range.

Important References: Stebbins, R.C. 1985. A field guide to western reptiles and amphibians. The Peterson Field Guide Series, Houghton Mifflin Company, New York, NY; Csuti, B., A.J. Kimerling, T.A. ONeil, M.M.
Shaughnessy, E.P. Gaines, and M.M.P. Huso. 1997. Atlas of Oregon wildlife. Oregon State University Press, Corvallis, OR; Groves, C.R., B. Butterfield, A. Lippincott, B. Csuti, and J.M. Scott. 1997. Atlas of Idaho's wildlife. Idaho Department of Fish and Game, Boise, ID. 


\section{Great Plains Narrowmouth Toad}

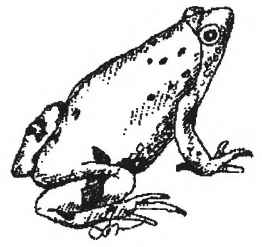

Global Rank: G5

State Rank: S1 (CO, NM); S3 (AZ)

Distribution: In the 11 western states, the Great Plains narrowmouth toad occurs in south-central Arizona (Santa Cruz and Pima Counties), in extreme southwestern New Mexico (Luna County near Mexican border), and southeastern Colorado (Baca and Los Animas Counties). It is also found in central Mexico and east of the Continental Divide from southeastern Nebraska south through most of Kansas, Oklahoma, and Texas, and western parts of Missouri, Arkansas, and Louisiana. It extends from near sea level to around 4,100 ft. $(1,250 \mathrm{~m}$.) in elevation.

Description: Adults reach up to $11 / 2$ in. (2-4 $\mathrm{cm}$.) in snout-vent length. The small plump body has smooth skin (occasionally spotted) and a fold of skin just behind the pointed head. The hind legs are short and stout. Fingers and toes lack webbing. Young have a dark leafshaped pattern covering up to half the width of

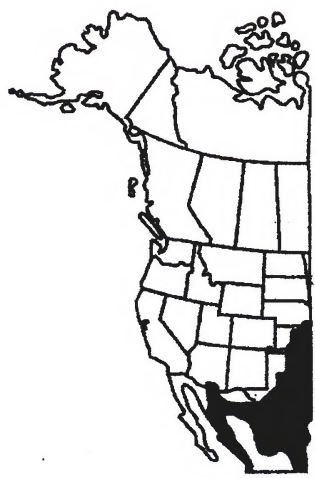

Current range of the Great Plains narrowmouth toad the back which fades with growth. Adult males have dark throats and small tubercles on the 
lower jaw and chest. The vocal sac is round and about the size of a pea. The voice has been described as a peep followed by a buzz like that of an angry bee.

Reproduction: Breeding takes place in temporary pools and in larger semi-permanent ponds behind earthen dams. It occurs within a few days after rains from mid-March through August. Calling may occur in both day and night, but usually more vigorously at night. Females deposit up to several hundred eggs which hatch in about two days. Metamorphosis from larvae requires about 3-4 weeks, and toadlets disperse from the ponds when the next rainfall facilitates overland travel.

Food: This toad feeds almost exclusively on ants. Feces examinations have found nearly entirely ant remains and a few beetle fragments.

Habits: The secretive toad hides by day in damp burrows, crevices, and under rocks, bark, and boards in the vicinity of streams, springs, and rain pools. It ranges from mesquite grassland to oak woodland habitats.

Management Implications: The species is considered endangered by the New Mexico Department of Game and Fish, but appears to be stable in Colorado and possibly Arizona. An interesting sidebar is the association of the toad with tarantula spiders. Up to nine narrowmouth toads have been found in tarantula burrows with live tarantulas. It has been speculated that the two species benefit each other in that the spider protects the toads from foraging snakes and the toads eat marauding ants after the tarantula eggs and young.

Important References: Stebbins, R.C. 1985. A field guide to western reptiles and amphibians. The Peterson Field Guide Series, Houghton Mifflin Company, New York, NY; Degen- hardt, W.G., C.W. Painter, and A.H. Price. 1996. Amphibians and reptiles of New Mexico. University of New Mexico Press, Albuquerque, NM; Hammerson, G.A. 1999. Amphibians and reptiles in Colorado. University Press of Colorado, Niwot, CO. 


\section{Great Plains Toad}

Bufo cognatus

Family Bufonidae

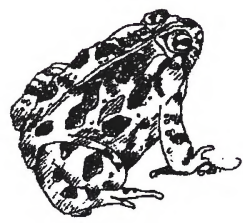

Global Rank: G5

State Rank: S3 (NV, UT, WY); S3S4 (MT); S4 (CO); S5 (AZ, NM)

Distribution: Extends from the Great Plains from extreme southern Canada to San Luis Potosi, Mexico, and western Texas to extreme southeastern California. Of the 11 eleven western states, they have extensive habitat in Montana, New Mexico, and Arizona, and lesser amounts in semi-arid parts of Wyoming, Colorado, Utah, Nevada, and California.

Description: Adults reach up to $41 / 2$ in. $(11.2 \mathrm{~cm}$.) in snout-vent length. Backs have well-defined, pale-bordered dark blotches in symmetric pairs. Cranial crests diverge widely toward the rear and loosely united on the snout to form a boss. There are sharp-edged inner tubercles on each hind foot. Coloration is usually light brown, olive, or gray above, with dusky, olive, or green blotches, sometimes with a narrow middorsal stripe. Whitish below and usually unspotted. Young have

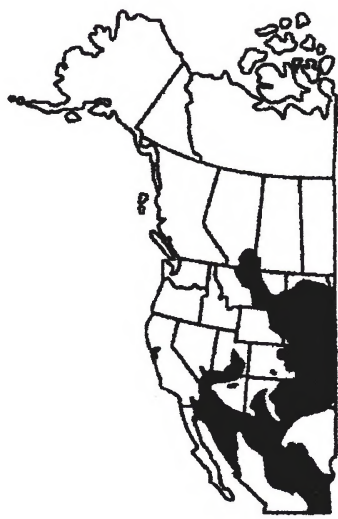
numerous small, brick-red tubercles, and " $v$ " shaped crests. Adult males have dark loose skin of the deflated vocal sac often partly concealed by a pale skin flap. Voice is a harsh explosive clatter lasting up to a minute. 
Reproduction: Breeding behavior reflects a relatively-short, high-density pattern related to spring and summer rainfall. Rain-filled ditches and temporary ponds are usually selected for breeding although permanent ponds and irrigated fields may also be used. Females are usually larger than males. The average clutch size is over 11,000 eggs (range 1,342 to $45,054)$. Some females may lay two clutches a year. The period from egg laying to when toadlets go through metamorphosis and emerge varies from 18 to 49 days.

Food: The diet of these toads has been found to be about 47 percent ants and 44 percent termites. They are also known to eat moths, caterpillars, flies, beetles, and other small arthropods.

Habits: Inhabits prairies, deserts, and agricultural areas, especially along floodplains of streams. This toad normally only enters water to breed. Inactive periods are spent burrowed in the ground, under rocks and wood, or in cracks of drying mud. Usually nocturnal in activity.

Management Implications: The toad can store as much as 30 percent of its body weight as water. This allows it to survive long periods of drought and to forage far from its water source. It may hybridize with other toads within its range.

Important References: Stebbins, R.C. 1985. A field guide to western reptiles and amphibians. The Peterson Field Guide Series, Houghton Mifflin Company, New York, NY; Degenhardt, W.G., C.W. Painter, and A.H. Price. 1996. Amphibians and reptiles of New Mexico. University of New Mexico Press, Albuquerque, NM; Hammerson, G.A. 1999. Amphibians and reptiles in Colorado. University Press of Colorado, Niwot, CO. 


\section{Green Toad}

\section{Bufo debilis \\ Family Bufonidae}

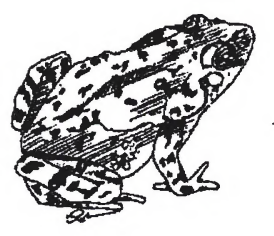

Global Rank: G5

State Rank: S2 (CO); S3 (AZ); S4 (NM)

Distribution: Ranges from southeastern Colorado and southwestern Kansas to Zacatecas, Mexico, and from southeastern Arizona to Texas. In New Mexico, the green toad occurs in the southeastern half of the state. In most of their range, they may reach as high as $4,000 \mathrm{ft} .(1,220 \mathrm{~m}$.) in elevation. In a few locations, they extend to above $6,000 \mathrm{ft}$. $(1,830 \mathrm{~m}$.) in elevation.

Description: Adults reach up to 2 in. $(5 \mathrm{~cm}$.) in snout-vent length. This small, flat, green or yellow-green toad has small black spots and bars on its back. The black marking may be more or less united to form a network. There are large, elongate, widely separated paratoids. Cranial crests are weak or absent. The belly is white. Adult males have a dark throat; females are yellow or cream. The vocal sac is round, and the voice is a wheezy buzz lasting for up to 10 seconds.

Reproduction: The toad breeds in shallow

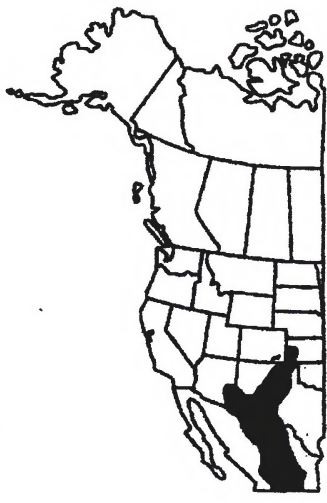
temporary rain pools, fishless stock ponds, or 
along intermittent streams. Arrival at the breeding areas coincide with the start of summer rains, usually during the first couple of weeks in July, but could occur from April to August. Grass around pools usually sought as spawning sites. Metamorphosis normally takes place in late July to mid-August, although newly transformed toadlets have been found into late September.

Food: Diet is believed to be a large variety of small invertebrates including ants, beetles, and moths.

Habits: The green toad is a species of arid and semiarid plains, valleys, and foothills (treeless or with scattered shrubs and trees). Frequents grasslands, mesquite savannahs, and creosote flats. Usually not found on steep slopes or in barren rocky areas. This secretive, burrowing, nocturnal toad, generally abroad only for brief periods during and after rains.

Management Implications: There is little known about the natural history of this toad.

Important References: Stebbins, R.C. 1985. A field guide to western reptiles and amphibians. The Peterson Field Guide Series, Houghton Mifflin Company, New York, NY; Degenhardt, W.G., C.W. Painter, and A.H. Price. 1996. Amphibians and reptiles of New Mexico. University of New Mexico Press, Albuquerque, NM. 


\title{
Idaho Giant Salamander
}

\author{
Dicamptodon aterrimus
}

Family Dicamptodontidae

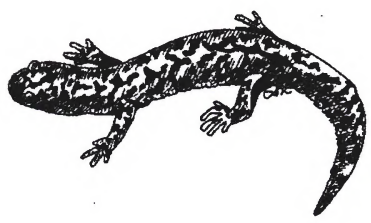

Global Rank: G3

State Rank: S3 (ID); SH (MT)

Distribution: Known from central Idaho and two locations in western Montana.

Description: Adult Idaho giant salamanders reach up to 13 in. $(33 \mathrm{~cm}$.) in total length. Key characteristics include bulky head and body with muscular legs; light tan or bronze finegrained marbling patterns on a dark brown or black background; and vertical grooves along sides are inconspicuous. Terrestrial adults are uncommon. Larvae reach up to $14 \mathrm{in}$. $(35 \mathrm{~cm}$.) in total length. Key characteristics are large size; small, bushy external gills; brown coloration with yellowish patches on back and sides; and a dorsal fin which starts at or behind the hind legs. The larvae may be locally common and may need to be in water for their gills to be visible. Most salamanders are voiceless, but adults of both the Idaho and Pacific giant salamanders are known to emit a low-pitched yelp when captured.

Reproduction: Breeding occurs in both spring and fall, usually in clear, cold streams. Large

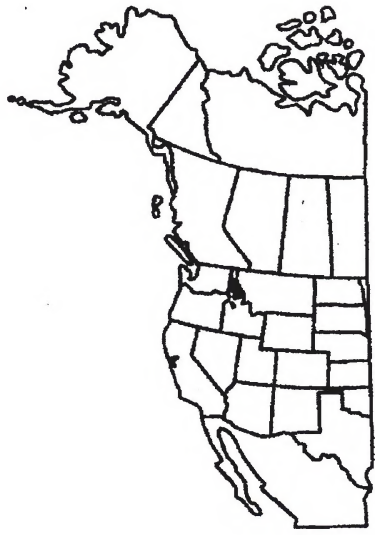

Current range of the Idaho giant salamander 
larvae sometimes become sexually mature and breed. Between 135 and 200 unpigmented eggs are laid singly and attached beneath logs or rocks. Eggs may be guarded by the adult females.

Food: Adults eat terrestrial invertebrates, small snakes, shrews, mice, and salamanders. Larvae feed on a wide variety of aquatic invertebrates and some small vertebrates such as fishes, tadpoles, and other larval salamanders.

Habits: Adults are usually found under rocks, bark, and logs in humid forests near mountain streams, or on rocky shores of mountain lakes. Larvae usually inhabit clear, cold streams, but are also found in mountain lakes and ponds. Terrestrial adults are seldom seen and are most active on warm, rainy nights.

Management Implications: The salamander is fairly common in suitable habitat in central Idaho, but are only known from two locations in Montana. Protection and frequent monitoring of those locations would seem important.

Important References: Groves, C.R., B. Butterfield, A. Lippincott, B. Csuti, and J.M. Scott. 1997. Atlas of Idaho's wildlife. Idaho Department of Fish and Game, Boise, ID; Peterson, C.R., and H.J. Fabian. 1997. Photographic identification cards for Idaho amphibians. Herpetology Laboratory, Idaho State University, Pocatello, ID; Reichel, J., and D. Flath. 1995. Identification of Montana's amphibians and reptiles. Montana Outdoors (May/June), Helena, MT. 


\section{Jemez Mountains Salamander}

\section{Plethodon neomexicanus}

Family Plethodontidae

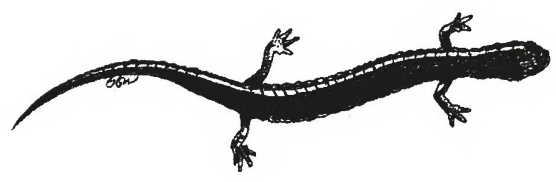

Global Rank: G2

State Rank: S2 (NM)

Distribution: The species is endemic to northcentral New Mexico where it is found only in the Jemez Mountains in portions of Los Alamos, Sandoval, and Rio Arriba Counties. Elevations are usually above $7,000 \mathrm{ft}$. (2,130 m.).

Description: Adults average about 3 in. (7.6 $\mathrm{cm}$ ) in total length. The body form is slender and elongate, with 18 to 20 coastal grooves. There are about eight coastal folds between the toes of the adpressed limbs. The legs are short and the fifth toe is much reduced, projecting only slightly beyond the foot web. Coloration above is uniformly dark brown with occasional fine gold stippling dorsally. Below, coloration is sooty gray, being lighter on the chin and on the underside of the tail. The head is slightly wider than the body, especially in sexually mature males. Young have a faint gray or brassy dorsal stripe.

Reproduction: Females are larger than males

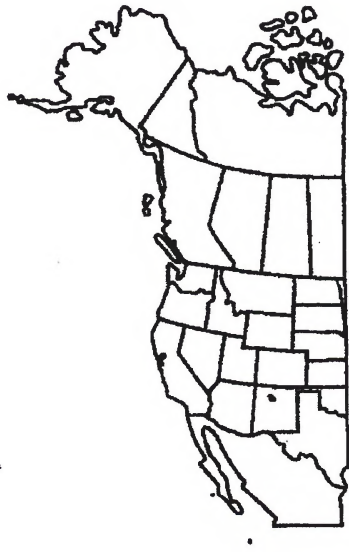

Current range of the Jemez Mountains salamander with sexual maturity reached at three to four years in females and three years in males. Egg 
deposition probably occurs in the spring, but may take place between August and the following spring. Eggs are laid beneath the soil surface in interstitial spaces between fractured rocks, in rotted root channels, or in the burrows of rodents or large invertebrates. $\mathrm{Egg}$ clutches are brooded by the females and probably average seven eggs. Juvenile salamanders have been found active on the surface as early as mid- to late-July.

Food: Prey includes mainly ants with lesser amounts of beetles and their larva, flies, termites, annelid worms, mites, snails, spiders, centipedes, and crickets. The variety of prey appears to increase later in the summer as more types become available.

Habits: The salamanders are generally found on loose rocky soils, in or under rotting coniferous logs or under rocks on both flat and steep slopes. Preferred habitat may be mosscovered rockslides, especially on north-facing slopes, in and near mixed forests of fir, spruce, aspen, and maple. It is a subterranean salamander that spends little time on the surface except during periods of summer rains.

Management Implications: The salamanders are highly restricted in range and vulnerable to some forest management practices. They should be protected from unregulated collecting and destruction of potential and occupied habitat. The New Mexico Department of Game and Fish lists the Jemez Mountains salamander as endangered and the U.S. Fish and Wildlife Service has done a status review on the species.

Important References: Stebbins, R.C. 1985. A field guide to western reptiles and amphibians. The Peterson Field Guide Series, Houghton Mifflin Company, New York, NY; Degen- hardt, W.G. 1996. Amphibians and reptiles of New Mexico. University of New Mexico Press, Albuquerque, NM. 


\title{
Kern Canyon Slender Salamander
}

\author{
Batrachoseps simatus \\ Family Plethodontidae
}

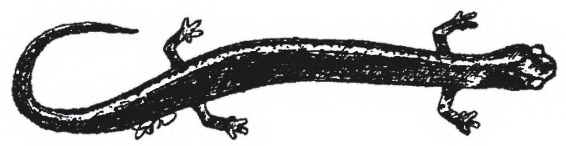

Global Rank: G1G2

State Rank: S2 (CA)

Distribution: Known only from the Kern River drainage in the southern Sierra Nevada (Kern and Tulare Counties) of California. Observed in all successional stages of blue oak savannah, and prefers digger pine-oak types. From $1,400 \mathrm{ft} .(430 \mathrm{~m}$.) to $6,300 \mathrm{ft}$. $(1,920 \mathrm{~m}$.) in elevation.

Description: Adults reach a little over 2 in. $(5.4 \mathrm{~cm}$.) in snout-vent length. This narrowheaded slender salamander has relatively long limbs and a long body and tail. Total length is about $11 / 2$ times the snout-vent length. The head and body are somewhat flattened, suggesting crevice-dwelling habits. There are 20 to 21 costal grooves and 7 to 9 costal folds between the toes of adpressed limbs. A vague dorsal stripe may be present. Sides and undersurfaces are dark, speckled with small light flecks.

Reproduction: Lays eggs in moist places under surface objects. Clutch size is unknown. It is believed to breed from November to

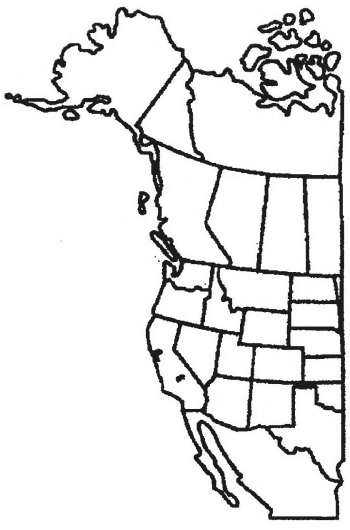

Current range of the Kern Canyon slender salamander February, with peak activity in November. 
Food: Diet is small insects and other invertebrates which are searched for under surface objects.

Habits: Occurs in isolated colonies along stream courses and on ridges and hillsides. North-facing slopes and shaded narrow tributary canyons seem to be favored. Found in talus slopes and under logs, litter, other surface objects, and moist soil, especially after rains. Frequents streamside vegetation of willows and cottonwoods, and slopes grown to interior live oak, canyon oak, and pine. Not thought to be territorial. Home ranges about a half acre in size.

Management Implications: Status is rare in California. It was first described in 1968 and little ecological information is available.

Important References: Stebbins, R.C. 1985. A field guide to western reptiles and amphibians. The Peterson Field Guide Series. Houghton Mifflin Company, New York, NY; Verner, J., and A.S. Boss. 1980. California wildlife and their habitats: western Sierra Nevada. USDA Pacific Southwest Forest and Range Experiment Station, GTR PSW-37, Berkeley, CA. 


\section{Larch Mountain Salamander}

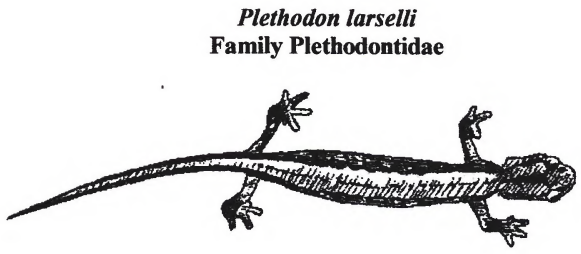

Global Rank: G2

State Rank: S2 (OR, WA)

Distribution: Once thought to be restricted to the Columbia River Gorge of Oregon and Washington, small populations occur at several locations in the Cascade Mountains of Washington as far north as Snoqualmie Pass. Reaches elevations of about $3,900 \mathrm{ft}$. $(1,190$ m.).

Description: Adults reach to about 4 in. (10 $\mathrm{cm}$.) in total length. The dorsal stripe is reddish, tan, or yellowish, tending to become obscure on the head. Stripes are edged with black or dark brown, and often speckled or heavily mottled with small dark flecks that may concentrate along the midline. Sides are black or dark brown sprinkled with white. Below, they are red to reddish orange or salmon-pink, brightest on the tail, and lightly speckled with black. Undersides of feet are usually reddish. The throats are cream or dull yellow. Toes are partly webbed and the fifth toe only has one joint. There are usually 18 or 19 costal grooves. Young have a less defined dorsal stripe, are darker, and have less red below.

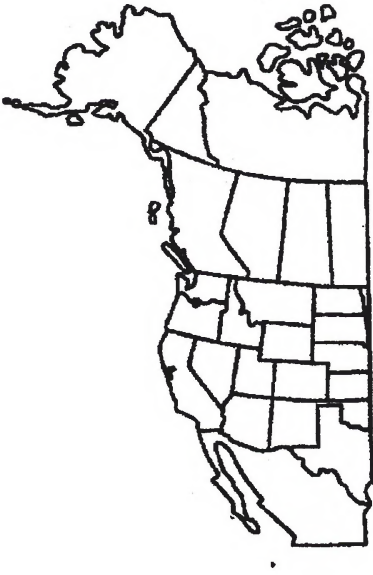

Current range of the Larch Mountain salamander

Reproduction: Breeds in both spring and fall. Nests probably occur deep in talus slopes. The 
average clutch size is seven.

Food: The species feeds on smaller invertebrates such as mites and springtails. Larger individuals also take snails and earthworms.

Habits: Found in talus slopes within areas of Douglas-fir forests. This tahus may have a covering of moss that is kept moist by the forest overstory. In very hot or cold conditions, the salamander retreats deep into the talus.

Management Implications: Distribution and abundance of the species is poorly known. Disturbance of the talus habitat should be avoided as microclimates within the talus can be destroyed by movement of rocks. It was formerly on the federal candidate list for both Oregon and Washington.

Important References: Stebbins, R.C. 1985. A field guide to western reptiles and amphibians. The Peterson Field Guide Series, Houghton Mifflin Company, New York, NY; Csuti, B., A.J. Kimerling, T.A. O'Neil, M.M. Shaughnessy, E.P. Gaines, and M.M. P. Huso. 1997. Atlas of Oregon wildlife. Oregon State University Press, Corvallis, OR. 


\section{Limestone Salamander}

\section{Hydromantes brunus}

Family Plethontidae

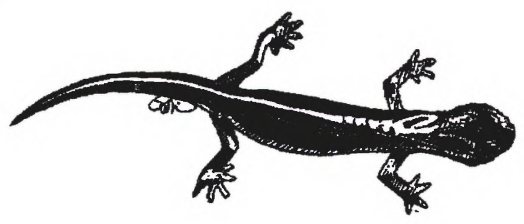

Global Rank: G1

State Rank: S1 (CA)

Distribution: Very limited distribution: vicinity of confluence of Bear Creek and Merced River in Mariposa County, California. Elevations range from $840 \mathrm{ft}$. $(255 \mathrm{~m}$ ) to $2,500 \mathrm{ft}$. (760 m.).

Description: Adults reach to about 3 in. (7.5 $\mathrm{cm}$.) in snout-vent length. Coloration is uniformly brown above and pale below. Underside of the tail is yellowish. Eyes are large and limbs, toes, and tail is relatively long. Toe tips of adpressed limbs overlap by $11 / 2$ costal folds. Young are pale yellowish green above, changing with age through pale yellow and beige to brown.

Reproduction: It is suspected that it breeds in limestone caverns from May to July, with a peak in June. The mean clutch size is 7 (range 5 to 14$)$.

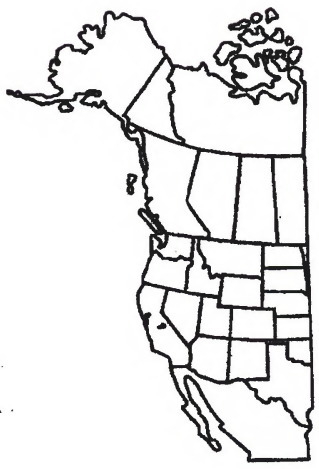

Food: Searches for insects and other inverte-

Current range of the limestone salamander 
brates under surface objects and in caverns.

Habits: Requires moist outcrops and caverns in digger pine, oak, buckeye, and chaparral belt of the lower Merced Canyon, California. Limestone salamanders live in crevices of cliffs and ledges and in talus, especially where the rocks are overgrown with moss. Active during period of fall, winter, and early spring rains, except during cold spells. Often coils its body when disturbed. It is not believed to be territorial, and home ranges may be as large as one acre (0.4 ha.).

Management Implications: California status is rare. The Briceburg State Ecological Reserve is within the range and offers habitat protection.

Important References: Stebbins, R.C. 1985. A field guide to western reptiles and amphibians. The Peterson Field Guide Series, Houghton Mifflin Company, New York, NY; Verner, J., and A.S. Boss. 1980. California wildlife and their habitats: western Sierra Nevada. USDA Pacific Southwest Forest and Range Experiment Station, GTR PSW-37, Berkeley, CA. 


\section{Long-toed Salamander}

\section{Ambystoma macrodactylum \\ Family Ambystomatidae}

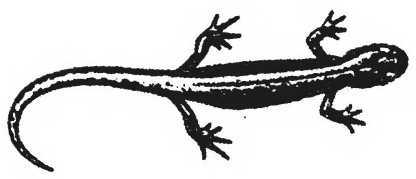

Global Rank: G5

State Rank: S2 (AK); S3 (CA);

S5 (ID, MT, OR, WA)

Distribution: From southeastern Alaska south along the coast to central Oregon and inland to the Rocky Mountains of Idaho and western Montana. Also found further south in the Sierra Nevada of California to Lake Tahoe. It ranges from near sea level to about $10,000 \mathrm{ft}$. $(3,000 \mathrm{~m}$.) in elevation. At least four subspecies have been identified and a relict population may exist in Santa Cruz County, California.

Description: Adult long-toed salamanders reach up to $6.25 \mathrm{in} .(16 \mathrm{~cm}$.) in total length. Key characteristics are a tan, yellow, or olivegreen dorsal stripe and elongated fourth toe of hind feet. The stripe often has irregular borders and a series of spots. There may be a sprinkling of fine white flecks on the sides.

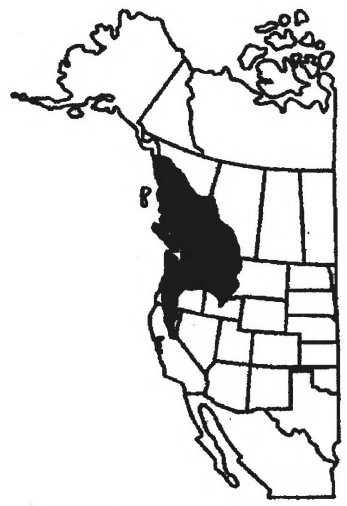

Belly coloration is usually dark brown or sooty. Larvae reach up to $3.1 \mathrm{in} .(8 \mathrm{~cm}$.) in total length. Key characteristics are long, feathery, external gills, may be visible only in water, 9-12 gill rakers, and uniform dorsal coloration. 
Reproduction: Adults begin migrating to the breeding waters after fall rains, and remain active most of the winter. Breeding can occur as early as January and February at low elevations and from April to July in the mountains. Clutch size is often larger at lower elevations, but can vary from 85 to 411 eggs. Eggs may be laid singly or in clusters of 5 to 100 and either attached to objects or loose on substrate. In colder areas, larvae may overwinter and transform to adults the next summer or fall.

Food: Adults eat terrestrial and aquatic invertebrates, including insects, insect larvae, spiders, slugs, earthworms, and amphipods. Larvae feed on zooplankton, immature insects, aquatic snails and probably other salamander larvae.

Habits: Adult long-toed salamanders are subterranean, except during the breeding season, and search for prey under surface objects such as rotting logs, bark, and rocks. They usually are near water and are usually active at night. They both hibernate and aestivate to avoid periods of cold or hot weather. Predators of adults are mainly garter snakes and bullfrogs; larvae are mainly preyed upon by aquatic insects and garter snakes.

Management Implications: This is the most common and widespread species of Ambystoma in the Northwest.

Important References: Stebbins, R.C. 1985. A field guide to western reptiles and amphibians. The Peterson Field Guide Series, Houghton Mifflin Company, New York, NY; Csuti, B., A.J. Kimerling, T.A. ONeil, M.M. Shaughnessy, E.P. Gaines, and M.M.P. Huso. 1997. Atlas of Oregon wildlife. Oregon State University Press, Corvallis, OR; Groves, C.R. B. Butterfield, A. Lippincott, B. Csuti, and J.M. Scott. 1997. Atlas of Idaho's wildlife.
Idaho Department of Fish and Game, Boise, ID. 


\section{Lowland Leopard Frog}

\section{Rana yavapaiensis \\ Family Ranidae}

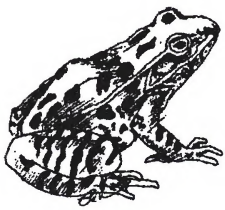

Global Rank: G4

State Rank: SH (UT); S1 (NM); S2 (CA); S4 (AZ)

Distribution: Found in the Colorado River drainage from the Virgin River in extreme northwestern Arizona and southwestern Utah to the Hoover Dam area to Yuma area in Arizona and extreme southeastern California, to the mouth of the Colorado River in Mexico, eastward through central and southeastern Arizona, dipping into Sonora, Mexico, and extreme southwestern New Mexico. Occurs from near sea level to around 4,800 ft. $(1,460$ m.) in elevation.

Description: Adults reach around 5 1/2 in. $(13.5 \mathrm{~cm}$.) in snout-vent length. Colorations are tan, gray-brown, or light gray-green to green above, and yellow below. They have dorsolateral folds, tuberculate skin, and usually vague upper lip stripes. Chins are mottled in older individuals. There is a dark network on the rear of the thighs, and yellow groin color often extends to the rear of the belly and underside of legs. Adult males have swollen and darkened thumb bases. The voice is low, guttural, chuckle like, at a fast repeating rate.

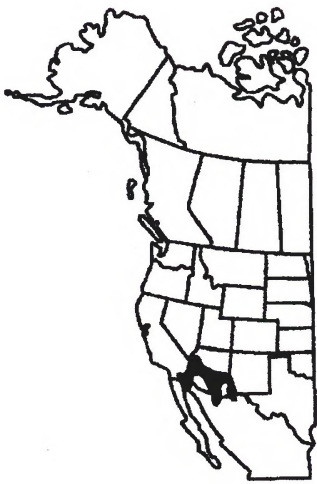

Current range of the lowland leopard frog 
Reproduction: There appears to be both a spring and fall breeding season peak. Egg masses and newly hatched tadpoles have been found in late February to late April. Tadpoles have sparse, discrete, small dark blotches on the tail, and the tail is 50 to 65 percent of the body length. Metamorphosis occurs after the tadpoles reach a little over $1 \mathrm{in} .(3 \mathrm{~cm}$.) in length.

Food: Unknown, but they probably eat a wide variety of insects and other invertebrates.

Habits: The frogs frequent desert, grassland, oak, and oak-pine woodland habitats, entering the permanent pools of foothills, overflow ponds and side channels of major rivers, permanent springs, and, in drier areas, more or less permanent stock ponds. Usually stay close to water.

Management Implications: Also known as the Yavapai leopard frog. It has undergone a status review by the U.S. Fish and Wildlife Service and is classified as endangered by the New Mexico Department of Game and Fish. Populations would be especially susceptible to events such as severe floods and droughts.

Important References: Stebbins, R.C. 1985. A field guide to western reptiles and amphibians. The Peterson Field Guide Series. Houghton Mifflin Company, New York, NY; Degenhardt, W.G., C.W. Painter, and A.H. Price. 1996. Amphibians and reptiles of New Mexico. University of New Mexico Press, Albuquerque, NM. 


\section{Mountain Treefrog}

\section{Hyla eximia}

Family Hylidae

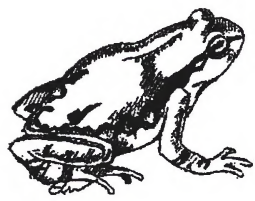

Global Rank: G4

State Rank: S2 (NM); S4 (AZ)

Distribution: Extends from the mountains of central Arizona and southwestern New Mexico, with an isolated population in the Huachuca Mountains of Cochise County, Arizona. Occurs in the Sierra Madre Occidental of northwestern Mexico as far south as Guerrero. Ranges from around 3,000 ft. (910 $\mathrm{m}$.) to $9,500 \mathrm{ft}$. $(2,900 \mathrm{~m}$.) in elevation.

Description: Adults reach up to $21 / 4$ in. (5.6 $\mathrm{cm}$.) in snout-vent length. They are green to brownish above with a dark line extending from the snout posteriorly through the eye onto the side of the body where it breaks into several segments. The posterior surfaces of the femur and groin are orange or gold with a greenish tinge. Adult males have dull greenish and $\tan$ throats compared to whitish in females. Toe pads are distinct, but small. Males are slightly smaller than females. The voice is a vibrant, repeated crreck or prreep speeding up or rising near the end. Tails of tadpoles are half to two-thirds of the total body length, and

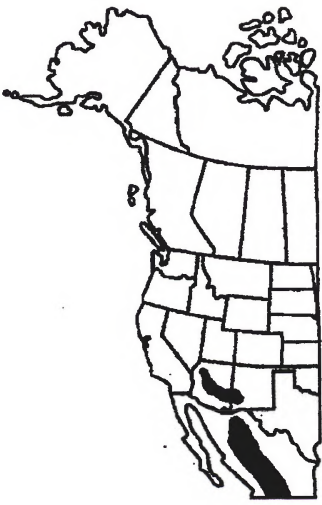

Current range of the mountain treefrog eyes are slightly displaced dorsally and cannot 
be seen from the ventral view. Dark melanophores are scattered over the body and base of tail above and mostly free of pigmentation below.

Reproduction: Breeding occurs in June through August during and after rains. Small, loose clusters of eggs are laid the day after breeding and attached to vegetation in shallow water. Tadpoles undergo metamorphosis between mid-September and mid-October.

Food: Known to feed on beetles (including bark beetles), spiders, earthworms, flies, and grass particles.

Habits: These small frogs occur at high elevations in coniferous forests of ponderosa pine and Douglas-fir. They occur along small streams, in wet meadows and cienegas, and in roadside ditches with temporary water. They are believed to climb to considerable heights in trees.

Management Implications: The species is relatively common in its preferred habitat. It appears to be fairly toxic in that there are several reports of severe burning of the eyes after handling the treefrogs. Bark beetles are well known pests in pine forests, and mountain treefrogs may help to control them.

Important References: Stebbins, R.C. 1985. A field guide to western reptiles and amphibians. The Peterson Field Guide Series. Houghton Mifflin Company, New York, NY; Degenhardt, W.G., C.W. Painter, and A.H. Price. 1996. Amphibians and reptiles of New Mexico. University of New Mexico Press, Albuquerque, NM. 


\title{
Mountain Yellow-legged Frog
}

\author{
Rana muscosa
}

Family Ranidae

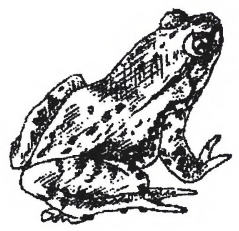

BLM Status: Sensitive (CA)

Global Rank: G2

State Rank: S1 (NV); S2 (CA)

Distribution: Found in the Sierra Nevada of California from around $4,500 \mathrm{ft}$. $(1,370 \mathrm{~m}$.) to over $12,000 \mathrm{ft}$. $(3,650 \mathrm{~m}$.) in elevation, with an isolated population in Butte County, north of Feather River Mountains of Southern California from Pacoima River south with southernmost populations on Mount Palomar. A population on Mount Rose, Nevada, probably previously occurred around Lake Tahoe.

Description: Reaches up to over 3 in. (7.8 $\mathrm{cm}$.) in snout-vent length. Yellowish or reddish brown above, with black or brown spots or lichenlike marking. Toe tips usually dusky. Undersides of hind legs and sometimes entire belly is yellow or orange. Dorsolateral folds present but frequent indistinct. Adult males have swollen, darkened thumb base. The voice is a faint clicking sound. It apparently lacks vocal sacs.

Reproduction: Breeds in May to August as

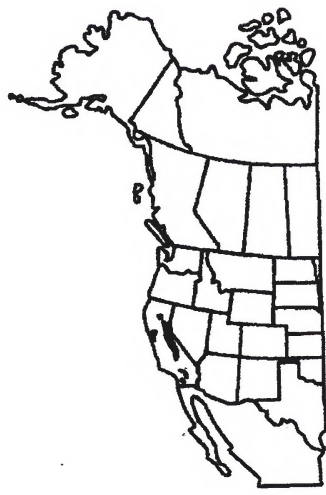

Current range of the mountain yellow-legged frog 
soon as meadows and lakes are free of ice, and March to June at lower elevations when high water in streams subsides. Eggs laid in rivers, streams, ponds, and lakes with peak activity in June. Mean clutch size is 200 to 300 eggs (range 100 to 500 ). Tadpoles may overwinter.

Food: Eats a variety of invertebrates which it catches at the edges of streams and ponds.

Habits: The only frog in the Sierra highlands of California. This is a frog of sunny riverbanks, meadow streams, isolated pools, and the mountain lakes of southern California. Prefers sloping banks with rocks or vegetation to the water's edge. Seldom found more than two or three jumps from water. Chiefly diurnal.

Management Implications: Numbers reduced at high mountain lakes when trout introduced. Populations in southern California appear to be dying out.

Important References: Stebbins, R.C. 1985. A field guide to western reptiles and amphibians. The Peterson Field Guide Series. Houghton Mifflin Company, New York, NY; Verner, J., and A.S. Boss. 1980. California wildlife and their habitats: western Sierra Nevada. USDA Pacific Southwest Forest and Range Experiment Station, GTR PSW-37, Berkeley, CA. 


\section{Mount Lyell Salamander}

\section{Hydromantes platycephalus \\ Family Plethodontidae}

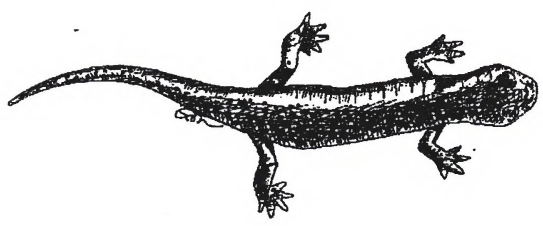

Global Rank: G4

State Rank: S3S4 (CA)

Distribution: Found in Sierra Nevada from Sierra Buttes, Sierra County, to Franklin Pass area, Tulane County, Twin Lakes, Silliman Gap, Sequoia National Park, and Mount Williamson, California. Low-altitude records are from the upper edge of the talus slopes on the south side of Yosemite Valley. Elevations range from $4,000 \mathrm{ft}$. $(1,220 \mathrm{~m}$.) to $12,000 \mathrm{ft}$. $(3,660 \mathrm{~m}$.).

Description: Adults reach about 3 in. (10.5 $\mathrm{cm}$.) in total length. Has a flattened head and body, a granite-matching coloration, blunt webbed toes, and a short tail. It is dusky below, flecked with white. Usually $1 / 2$ to $11 / 2$ costal folds between adpressed limbs. Young have black color above, overlain with a greenish tinge.

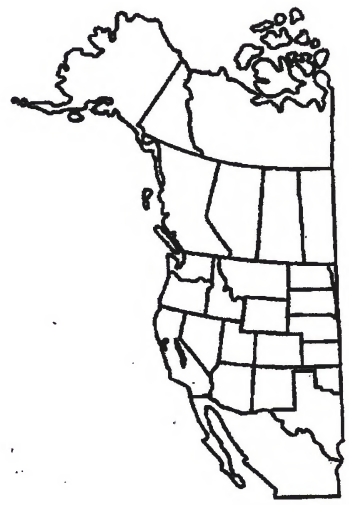

Reproduction: Breeding season is unknown. The peak is thought to be May and June depending on the year. Both clutch size and nest

Current range of the Moumt Lyell salamander 
Food: Feeds on insects and spiders found under surfaces.

Habits: Found in wet areas (springs and seeps), under large granite slabs and boulders at the base of talus slopes. Typical habitat includes rock fissures, seepages from streams and melting snow, shade, and low-growing plants. Active from late spring to fall. Seems to prefer north-facing slopes.

Management Implications: A fragile species; total population relatively small and composed of scattered local populations. Thought to be a relic of a once widespread species in past Sierra glacial periods.

Important References: Stebbins, R.C. 1985. A field guide to western reptiles and amphibians. The Peterson Field Guide Series. Houghton Mifflin Company, New York, NY; Verner, J., and A.S. Boss. 1980. California wildlife and their habitats. USDA Pacific Southwest Forest and Range Experiment Station, GTR PSW-37, Berkeley, CA. 


\section{Northern Casque-headed Frog}

\section{Pternohyla fodiens \\ Family Hylidae}

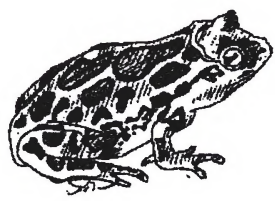

Global Rank: G4

State Rank: S1S2 (AZ)

Distribution: In the United States, the only habitat is in the San Simon Valley between Sells and Ajo, Arizona, north to near Hichiwan, Pima County, Arizona. In Mexico, the range extends south in western Mexico from Sonora to Michoacan. Extends from near sea level to about $4,900 \mathrm{ft}$. $(1,490 \mathrm{~m}$.) in elevation.

Description: Reaches up to about $21 / 2$ in. $(6.2 \mathrm{~cm}$.) in snout-vent length. The upper surface of the head is very hard and the skin is firmly attached. There is a prominent ridge between the eyes and the nostrils and a fold of skin at the back of the head. Toe pads are small but distinct. A single large whitish tubercle is on each hind foot. Coloration is brown or pale yellow on upper surfaces, with large, dark brown spots edged with black. Lower surfaces are plain white. Adult males have a dark patch on each side of the throat. They have a large vocal sac which looks slightly bilobed when viewed from the front. The voice

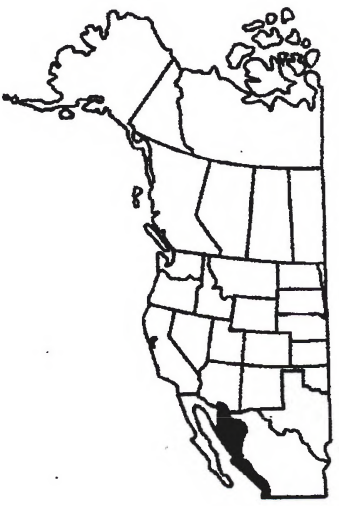

Current range of the casque-headed frog is a loud, low-pitched walk, walk, walk given 2 to 3 per second and all at one pitch. 
Reproduction: Breeds in June to September during periods of summer rains. After the first hard rains in July, choruses quickly form around temporary pools.

Food: Believed to be a variety of invertebrates.

Habits: The northern casque-headed frog is a terrestrial, burrowing, nocturnal frog of open terrain and tropical scrub forests. Occurs in mesquite grassland in extreme southern Arizona.

Management Implications: Mainly an amphibian of western Mexico, only habitat in the United States is in extreme southcentral Arizona.

Important References: Stebbins, R.C. 1985. A field guide to western reptiles and amphibians. The Peterson Field Guide Series. Houghton Mifflin Company, New York, NY. 


\section{Northern Cricket Frog}

Aeris crepitans

Family Hylidae

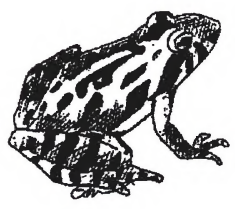

Global Rank: G5

State Rank: S4 (NM); SH (CO)

Distribution: Occurs throughout most of the middle and eastern parts of the United States, and into northeastern Mexico and Ontario, Canada. In the west, it is now restricted to southeastern New Mexico and eastern Colorado. It formerly occurred as far west as Arizona and possibly Utah, but is now considered to be extinct in those states. It has not been seen in Colorado since 1979, and may no longer be present there. In New Mexico, the Blanchard's subspecies (A. C. blanchardi) is often abundant along the permanent springs and rivers of the Pecos River drainage of Eddy and Chaves Counties. It also may occur in DeBaca County near Fort Sumner and between Roswell and Fort Sumner. It ranges between $2,950 \mathrm{ft}$. $(900 \mathrm{~m}$.) and $3,600 \mathrm{ft}$. $(1,100 \mathrm{~m}$.) in elevation, and may occur as high as $4,000 \mathrm{ft} .(1,225 \mathrm{~m}$.) in DeBaca County.

Description: Adults reach up to $11 / 2$ in. (3.7 $\mathrm{cm}$.) in snout-vent length. It is a small, slim-

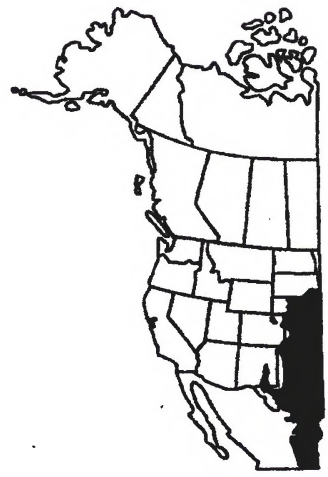

Current range of the northern cricket frog 
waisted frog with slender webbed toes and a triangular mark on the head. There are no toe pads. Coloration is gray, light brown, green, reddish, or reddish green above, usually with a middorsal stripe of similar color. The gray form is common in the western and northern parts of its range. There are dark markings on the back and dark bands on the legs. White bars extend from eyes to base of forelegs, and a dark stripe is found on the rear of the thigh. Adult males have dusky throats, suffused with yellow, and more spotting than in females below. The voice is a metallic gick, gick, gick, about one call per second, with the rate gradually increasing. The vocal sac is round.

Reproduction: Calling begins in mid-March and continues until mid-September, both day and night. Breeding takes place between late April and mid-June. Females deposit between 200 and 400 eggs on aquatic vegetation, either singly or in small clusters. Some females may lay two clutches during the breeding season. Larvae are in the ponds from early May to early August, and metamorphosis occurs by mid-August.

Food: Food habits largely unknown. Likely to feed on a variety of invertebrates including beetles, ants, true bugs, caterpillars, caddisflies, and annelid worms.

Habits: The preferred habitat is low, sunny, marshy areas along rivers, streams, and desert springs where there is abundant vegetation. They bask on sunny banks of shallow pools, often in groups. Individuals scatter when frightened, leaping high and fast, or skittering over the surface of the water. They are active all year except for mid-winter at higher elevations.

Management Implications: This species is believed to be a relic species in the Chihuahuan Desert of New Mexico, and is existing in disjunct populations considerably removed from the main portion of the range. It apparently has become extinct in Arizona and possibly Utah within the last hundred years, and has not been seen in Colorado since 1979. This may indicate the need to protect their preferred habit.

Important References: Stebbins, R.C. 1985. A field guide to western reptiles and amphibians. The Peterson Field Guide Series, Houghton Mifflin Company, New York, NY; Degenhardt, W.G., C.W. Painter, and A.H. Price. 1996. Amphibians and reptiles of New Mexico. University of New Mexico Press, Albuquerque, NM; Hammerson, G.A. 1999. Amphibians and reptiles in Colorado. University Press of Colorado, Niwot, CO. 


\section{Northern Leopard Frog}

\section{Rana pipiens}

Family Ranidae

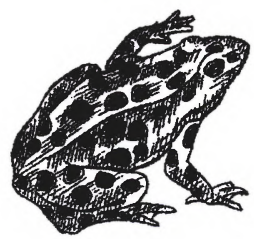

BLM Status: Sensitive (ID, OR)

Global Rank: G5

State Rank: S1 (WA); S2 (AZ, CA, OR); S3 (CO, ID, NV, WY); S3S4 (MT); S4 (NM); S4S5 (UT)

Distribution: Widely distributed from the Northwest Territories to mid-Arizona and New Mexico and from Nevada to the New England coast in a line northeasterly from southeastern Colorado. Populations along the Snake River drainage in Idaho and the Rocky Mountains in Montana. Isolated populations occurred in Oregon and Washington, and the species has been widely introduced into western states.

Description: Aduit northern leopard frogs reach up to 4 in. $(10 \mathrm{~cm}$.) in snout-vent length. Key characteristics include 12 or 13 dark, oval spots with a light halo between the dorsolateral folds on the back with the two

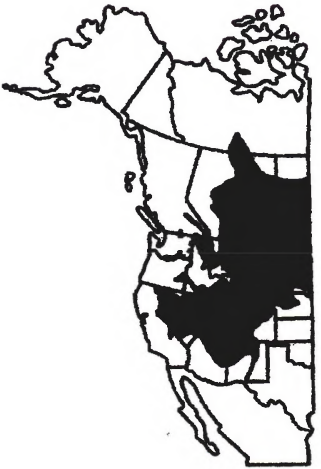
anterior-most spots overlapping the dorsolateral folds. The hind limbs are barred or spotted. General coloration is dark brown to light green on the dorsal surface and white on the belly. The skin is smooth, the hind feet are moderately webbed, and relatively long. Tad- 
poles reach up to $3.3 \mathrm{in}$. $(8.5 \mathrm{~cm}$.) total length and have key characteristics of brown or gray dorsal coloration with metallic flecks; light or transparent ventrally; intestines visible; tail fins translucent; and eyes dorsally located. Adult males develop swollen, darkened thumb base and loose skin between the jaw and shoulder during breeding season. Voice is a low "motorboat" or snorelike sound, interspersed with grunting and chuckling, and lasting about one to five seconds. Paired vocal sacs expand over the forelimbs.

Reproduction: The frogs gather at breeding ponds in the spring after water temperatures have warmed to about 50 degrees. Up to 6,000 eggs are laid in flattened spheres and usually attached to vegetation in shallow water. Many females may deposit their eggs in the same site. The tadpole stage lasts about two months and they usually emerge by early August. Partly transformed tadpoles with hind legs have been found in September at higher elevations, but these probably do not survive or overwinter in the larval form. Adults reach sexual maturity in two years.

Food: Carnivorous adults eat invertebrates such as snails, leeches, spiders, small insects, and vertebrates such as birds, garter snakes, tadpoles, small frogs, and fish. They have been known to be hooked by fishermen using earthworms and small artificial flies. Larvae feed on algae, plant tissue, organic debris, and probably small invertebrates.

Habits: Northern leopard frogs are found in or near permanent water in the plains, foothills, and montane zones, with preferred habitats of swampy cattail marshes at lower elevations and beaver ponds at higher elevations. They probably hibernate in the bottoms of streams and ponds during the winter, and may forage far from permanent water during damp weather. When disturbed, they leap rapidly and erratically. They are preyed upon by garter snakes and bullfrogs.

Management Implications: Northern leopard frog populations have decreased in numerous parts of their range. Predation by bullfrogs are probably a factor, and may have caused reductions or extinction of populations in Oregon and Washington. The species has been widely collected for use as biological specimens, but the impacts of this on population viability is unknown.

Important References: Stebbins, R.C. 1985. A field guide to western reptiles and amphibians. The Peterson Field Guide Series, Houghton Mifflin Company, New York, NY; Baxter, G.T., and M.D. Stone. 1980. Amphibians and reptiles of Wyoming. Wyoming Game and Fish Department, Cheyenne, WY; Csuti, B., A.J. Kimerling, T.A. O'Neil, M.M. Shaughnessy, E.P. Gaines, and M.M.P. Huso. 1997. Atlas of Oregon wildlife. Oregon State University Press, Corvallis, OR; Groves, C.R., B. Butterfield, A. Lippincott, B. Csuti, and J.M. Scott. 1997. Atlas of Idaho's wildlife. Idaho Department of Fish and Game, Boise, ID. 


\title{
Northwestern Salamander
}

\author{
Ambystoma gracile
}

Family Ambystomatidae

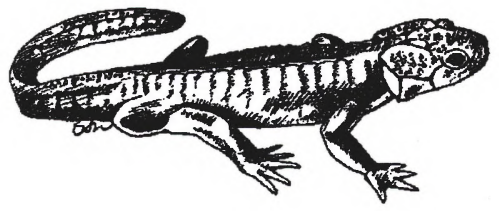

Global Rank: G5

State Rank: S2 (AK); S4 (CA); S5 (OR, WA)

Distribution: Found along the humid coast from extreme southeastern Alaska, chiefly west of the crest of the Cascade Mountains, to the mouth of Gualala River, California. Extends from near sea level to around $10,200 \mathrm{ft}$. $(3,110 \mathrm{~m}$.) in elevation.

Description: Adults reach around 9 in. (23 $\mathrm{cm}$.) in total length. Coloration is brown, gray, or black above with a broad head and relatively small eyes. They have parotoid glands and a glandular thickening along the upper border of the tail. The glandular areas are pitted with openings of poison glands and the skin there is rougher than elsewhere. No tubercles are on the underside of feet. The back may be flecked with cream or yellow in northern part of the range.

Reproduction: Migration between breeding and non-breeding habitats usually done during rainy nights. Spawns in ponds, lakes, and

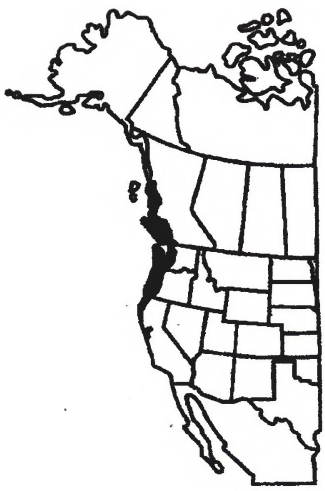
streams from January to August. Breeding is 
later in areas in the north and at higher elevations. Eggs are laid in clusters in quiet water and attached to vegetation one to three feet below the surface. Average clutch size is 80 eggs (range 30 to 270). Eggs usually hatch in May to July or after about 30 to 60 days. In colder areas, larvae may overwinter and some may be neotenic.

Food: Adults feed primarily on insects, earthworms, molluscs, and other terrestrial invertebrates. Larvae eat zooplankton and other aquatic invertebrates.

Habits: Resides in meadows, woodlands, and coniferous or deciduous forests. It spends most of its life underground in rodent burrows and under rocks and logs near water. Often found under driftwood on streambanks after storms when water is receding. The northwestern salamander is active at night and searches for food on the forest floor under debris.

Management Implications: It is preyed upon by introduced trout and may be sensitive to pesticides and herbicides that may enter breeding waters. When molested, adults close their eyes, assume a butting pose, elevate the tail, and secrete a sticky white poison from glands on the head, back, and tail. This secretion may cause skin irritation in some people.

Important References: Stebbins, R.C. 1985. A field guide to western reptiles and amphibians. The Peterson Field Guide Series. Houghton Mifflin Company, New York, NY; Csuti, B., A.J. Kimerling, T.A. O'Neil, M.M. Shaughnessy, E.P. Gaines, and M.M.P. Huso. 1997. Atlas of Oregon wildlife. Oregon State University Press, Corvallis, OR. 


\section{Olympic Salamander}

\section{Rhyacotriton olympicus}

Family Dicamptodontidae

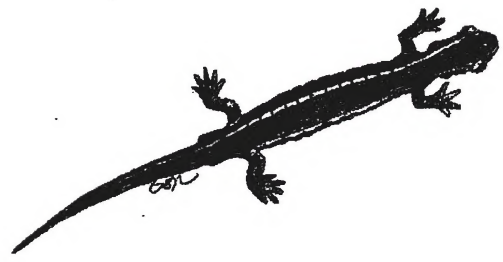

BLM Status: Sensitive (OR)

Global Rank: G2G3

State Rank: S2 (WA); S3 (OR)

Distribution: Found in coastal areas from the Olympic Peninsula, Washington, south to the vicinity of Point Arena, Medocino County, California. Inland populations west of Cascade crest from the vicinity of Lewis County, Washington, to the upper Umpqua River drainage, Douglas County, Oregon.

Description: Adults reach to about 4 in. (10 $\mathrm{cm}$.) in total length. Their small size and large eyes are distinctive among western aquatic and semiaquatic salamanders. The diameter of the eye opening roughly equals the distance between the front corner of the eye and the tip of the snout. The head is small, body is long, and limbs and tail are short. Coloration is plain brown or olive mottled with dusky above, and

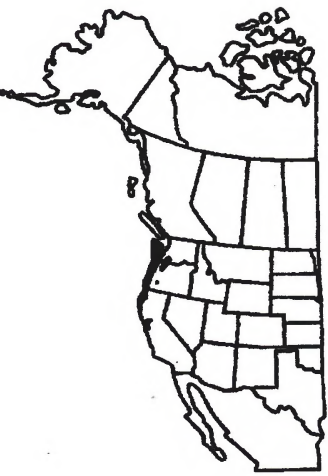

orange or yellow below. Males have prominent squarish vent lobes.

Reproduction: Most breeding occurs in spring and early summer with a lesser peak in 
fall and winter. Clutches of 7 to 16 eggs are laid which take up to 7 to 10 months to hatch. Larvae have short gills and adult proportions and live in clear shallow water, in the muck of seepages, and in accumulations of dead leaves in creeks. They are slow to metamorphose, perhaps requiring over three years to do so. Sexual maturity may take six to seven years to reach.

Food: The diet consists of aquatic and semiaquatic invertebrates, including amphibids, springtails, fly larvae, worms, snails, and spiders. They search for prey under rocks and other objects in streams.

Habits: The salamanders are most abundant in rocks bathed in a constant flow of cold water, and also occur in cool rocky streams, lakes, and seeps that are well-shaded and with banks covered with moss and ferns. They tend to remain in the splash zones of waterfalls within conifer and alder forests.

Management Implications: The Olympic salamander has been split taxonomically into three species: the Cascade torrent salamander ( $R$. cascadae) found in the Oregon Cascades as far south as northern Lane County; the Columbia torrent salamander ( $R$. kezeri) found in extreme northwestern Oregon; and the southern torrent salamander ( $R$. variegatus) found south of Tillamook County and in the Cascades of eastern Douglas County into California. The Columbia torrent salamander is a BLM sensitive species. Current ecological information does not differentiate between the three species, so this account applies to all three species.

Important References: Stebbins, R.C. 1985. A field guide to western reptiles and amphibians. The Peterson Field Guide Series. Houghton Mifflin Company, New York, NY; Csuti, B., A.J. Kimerling, T.A. O’Neil, M.M.
Shaughnessy, E.P. Gaines, and M.M.P. Huso. 1997. Atlas of Oregon wildlife. Oregon State University Press, Corvallis, OR. 


\section{Oregon Slender Salamander}

\section{Batrachoseps wrighti \\ Family Plethodontidae}

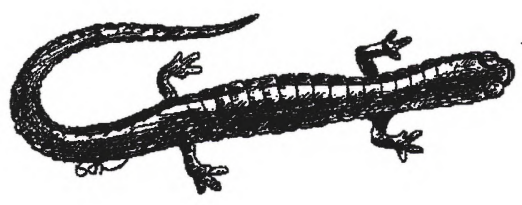

Global Rank: G3

State Rank: S3 (OR)

Distribution: The only amphibian endemic to Oregon, this species is found on the west slope of the Cascade Range from the Columbia River south to southern Lane County. From near sea level to around $4,700 \mathrm{ft}$. $(1,430 \mathrm{~m}$.) in elevation.

Description: Adult Oregon slender salamander reach around 3.5 in. $(9 \mathrm{~cm}$.) in total length. This long-legged, slender salamander has a black belly that is marked with large white blotches, 16 or 17 costal grooves, counting one each in axilla and groin. There are $41 / 2$ to $71 / 2$ costal folds between adpressed limbs. Dark brown color above, often with a reddish or yellow-brown or occasionally greenish gold stripe. In some, back color contrasts with brick-red tail.

Reproduction: Lays eggs underground or in rotting logs in spring or early summer. The egg clutch averages 6 (range 3-11), and hatch after about four months. Eggs are guarded by the females.

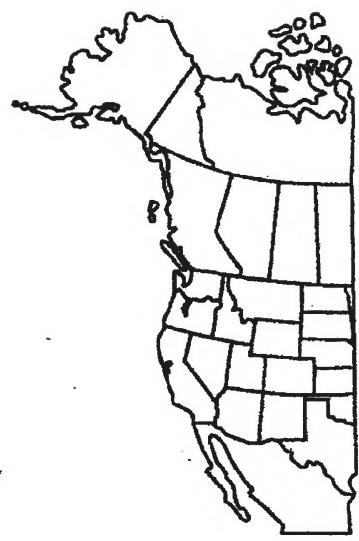

Current range of the Oregon slender salamander 
Food: Diet includes small invertebrates like springtails, mites, insect larvae and adults, spiders, snails, and earthworms.

Habits: Found under bark or moss in mature and second-growth Douglas-fir forests, as well as under rocks or logs in stands of moist hardwood forests within coniferous forest landscapes. Usually it is absent from recent clear-cuts, but it is sometimes found in talus and lava fields near the crest of the Cascades. This species can be found near the surface during fall and spring, but retreats underground in late spring and summer.

Management Implications: The species seems to be common in local areas, but is rare or absent throughout large portions of its range. It is known to occur at only a few dozen localities. The impacts of timber harvest practices on this species and its general distribution in the Cascade Mountains need to be investigated.

Important References: Stebbins, R.C. 1985. A field guide to western reptiles and amphibians. The Peterson Field Guide Series. Houghton Mifflin Company, New York, NY; Csuti, B., A.J. Kimerling, T.A. O'Neil, M.M. Shaughnessy, E.P. Gaines, and M.M.P. Huso. 1997. Atlas of Oregon wildlife. Oregon State University Press, Corvallis, $O R$. 


\title{
Oregon Spotted Frog
}

\author{
Rana pretiosa \\ Family Ranidae
}

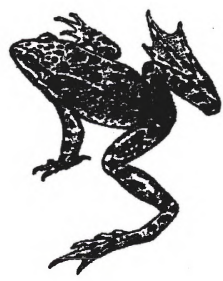

FWS Status: Candidate

BLM Status: Sensitive (OR, WA)

Global Rank: G2G3

State Rank: S1 (CA, WA); S2 (OR)

Distribution: Prior to 1996, the spotted frog was considered to be one species (Rana pretiosa) and the Great Basin population, a subspecies $(R, p$. luteiventris). Now considered two distinct species, the Oregon spotted frog (R. pretiosa) extends from the Cascade Mountains to the Pacific Coast in Oregon, and the Columbia spotted frog ( $R$. luteiventris) from central Oregon to the East. Species accounts are similar for both species until range maps and characteristics of each species are more fully developed. The overall range of the spotted frog extends from southeastern Alaska south through most of British Columbia and the western edge of Alberta; most of Idaho, Washington, and Oregon; western Montana; northwestern Wyoming; and isolated populations in higher elevations of northern Nevada and Utah. They occur from near sea level to about $10,000 \mathrm{ft}$. $(3,050 \mathrm{~m}$.) in eleva-

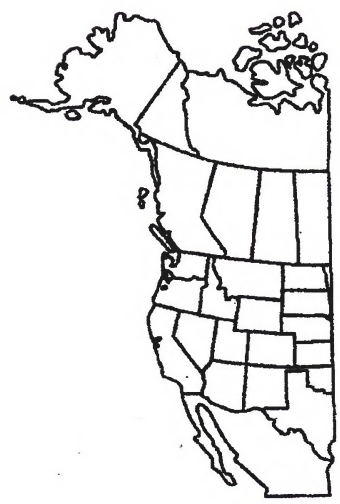
tion.

Current range of the Oregon spotted frog 
Description: Adult spotted frogs are about 3.5 in. $(9 \mathrm{~cm}$.) in snout-vent length. Key characteristics include dorsal black spots with "fuzzy" edges; white lip stripe; full webbing between hind toes; somewhat bumpy skin; pointed snout; and upturned eyes. Adult spotted frogs have yellow or red coloration on the underside of legs and belly; however, this coloration is usually lacking in juveniles. The voice is a series ( 4 to 50 ) of faint, rapid, lowpitched clicks, lasting up to about 10 seconds. The call may be given above and occasionally under water.

Reproduction: Frogs at lower elevations reach maturity at about two years of age, breed earlier in the year and on a yearly basis, and live about five years. At higher elevations, they mature more slowly, do not breed every year, and live longer. Breeding occurs from February in lower elevations to July in mountain locations. Eggs are laid in softball-sized clutches up to 2,400 eggs. Egg masses float on the surface and many females may deposit their eggs at the same site. Recently hatched tadpoles are black. As they grow, they become brownish green, flecked with gold, have medially located eyes, and the intestines are visible. Tadpoles may become as large as $3 \mathrm{in}$. ( $8 \mathrm{~cm}$.) before metamorphosing. Most tadpoles metamorphose their first year, except some may overwinter as larvae at high elevations.

Food: Adults eat a wide variety of insects, mollusks, and arachnids. Larvae eat algae, organic debris, plant tissue, and minute waterborne organisms.

Habitat: Spotted frogs are closely associated with water, being dependent on streams, rivers, marshes, springs, pools, and small lakes for overwintering, breeding, and foraging habitat. After breeding, they may move overland a considerable distance from water. Breeding areas are mostly shallow, standing water, springs, or slow moving and back-water portions of rivers and streams. For overwintering in cooler portions of their range, they may congregate in areas where the water does not freeze. Preferred habitat is usually areas with thick algae and emergent vegetation, but may use sunken, dead, or decaying vegetation as escape cover.

Management Implication: The introduced bullfrogs are a major threat to all stages of spotted frogs. Other threats include loss and fragmentation of habitat through factors such as livestock impacts (vegetation removal, trampling, changes in water quality), drought, water diversions, contaminants, and various kinds of developments. Importance of factors such as increased ultraviolet radiation, parasites, or other factors which may be causing world-wide declines in amphibians are still unknown.

Important References: Stebbins, R.C. 1985. A field guide to western reptiles and amphibians. The Peterson Field Guide Series; Houghton Mifflin Company, New York, NY; Csuti, B., A.J. Kimerling, T.A. O'Neil, M.M. Shaughnessy, E.P. Gaines, and M.M.P. Huso. 1997. Atlas of Oregon wildlife. Oregon State University Press, Corvallis, OR; Groves, C.R., B. Butterfield, A. Lippincott, B. Csuti, and J.M. Scott. 1997. Atlas of Idaho's wildlife. Idaho Department of Fish and Game, Boise, ID. 


\section{Pacific Chorus Frog}

\section{Pseudacris regilla \\ Family Hylidae}

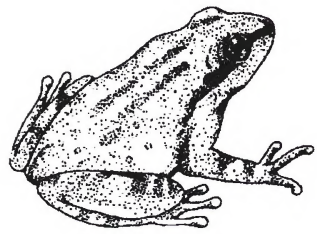

BLM Status: Sensitive (UT)

Global Rank: G5

State Rank: S1 (UT); S4 (MT); S5 (CO, ID, NV, OR, WA); SE2 (AZ)

Distribution: Formerly known as the Pacific treefrog (Hyla regilla), the species ranges along the west coast from southern British Columbia to Baja California and east to western Montana, and most of Idaho and Nevada. It appears to be the only native frog on islands off the coast of southern California. Several isolated desert populations in southern probably were introduced. It extends from sea level to about $11,600 \mathrm{ft}$. $(3,540 \mathrm{~m}$.) in elevation.

Description: Adult Pacific chonus frogs are about 1.9 in. $(4.7 \mathrm{~cm}$.) in snout-vent length. Key characteristics are the conspicuous dark mask, large toes tipped with large, round toe pads, and limited webbing. The dorsal coloration is highly variable (green, gray, brown, bronze, or reddish), but usually green or shades of brown. Individuals can quickly lighten or darken. There often is a "Y" mark between the eyes. Undersides are usually cream colored to yellowish on hindquarters.

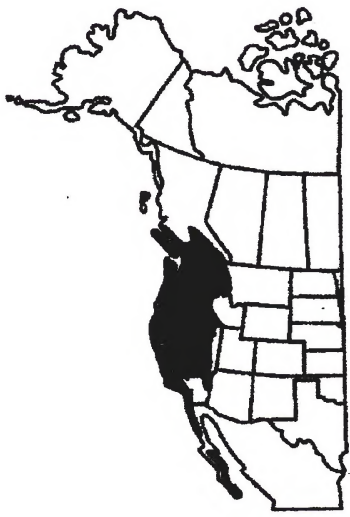

Current range of the Pacific chorus frog The throats of males are dusky and wrinkled, with a round vocal sac. The calls are often 
uttered in sequence of about one second each, , and are a loud, two parted kreck-ek with rising inflection on the last part.

Reproduction: Breeding occurs January through August. Usually prefers shallow, quiet waters for breeding. Eggs are laid in clusters of up to 80 eggs, and are loosely attached to objects or laid on substrate. Eggs hatch in 3-5 weeks, and tadpoles metamorphose in 2-3 months. Multiple clutches have been documented. Tadpoles reach up to $2.2 \mathrm{in}$. $(55 \mathrm{~mm}$.) prior to metamorphose, and are characterized by having brown color dorsally, white ventrally, eyes are laterally placed and project beyond the margin of the head when viewed from above.

Food: Larvae eat algae, organic debris, and plant tissue. Adults eat a variety of small invertebrates including beetles, flies, spiders, ants, and isopods.

Habits: The Pacific chorus frog is a common and widespread species, usually found in low vegetation near water during the breeding season. It is also found in grasslands, woodlands, forests, farmlands, and around human dwellings. Individuals are inactive during periods of cold temperatures, and frequently are nocturnal during dry periods. Both adults and larvae are preyed upon by bullfrogs, garter snakes, and many birds and mammals, and larvae are also eaten by carnivorous aquatic insects. In some waters, the species has probably been displaced by bullfrogs.

Management Implication: The main threat to the species is probably from the introduced bullfrog. In some cases, irrigation practices may drain waters where eggs have been laid and cause loss of productivity. The importance of increased ultraviolet radiation, parasites, and other factors which may be causing worldwide declines in amphibians are still unknown.
Important References: Stebbins, R.C. 1985. A field guide to western reptiles and amphibians. The Peterson Field Guide Series, Houghton Mifflin Company, New York, NY; Csuti, B., A.J. Kimerling, T.A. O'Neil, M.M. Shaughnessy, E.P. Gaines, and M.M.P. Huso. 1997. Atlas of Oregon wildlife. Oregon State University Press, Corvallis, OR; Groves, C.R. B. Butterfield, A. Lippincott, B. Csuti, and J.M. Scott. 1997. Atlas of Idaho's wildlife. Idaho Department of Fish and Game, Boise, ID. 


\title{
Pacific Giant Salamander
}

\author{
Dicamptodon tenebrosus
}

Family Dicamptodontidae

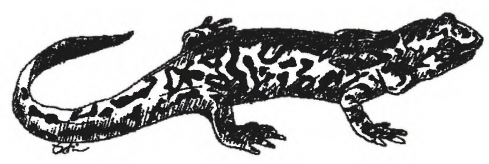

Global Rank: G5

State Rank: S4 (OR); S5 (WA); S? (CA)

Distribution: Found in coast ranges and Cascade Mountains from southern British Columbia to San Francisco Bay. Inland in northern California to headwaters of Sacramento River. Ranges from near sea level to around $7,000 \mathrm{ft} .(2,160 \mathrm{~m}$.) in elevation.

Description: Adults reach nearly 12 in. (30 $\mathrm{cm}$.) in total length. This is a large, formidablelooking salamander with a massive head and often marbled coloration. The skin is smooth and costal grooves inconspicuous. There are only two joints in fourth toe of hind foot. There are no foot tubercles. Dark brown coloration to almost black above, with a network of irregular spots or marbling of tan, copper, gray, or purplish. Ground color darkens in northern populations.

Reproduction: While the reproductive biology of this species is poorly known, it probably breeds in the spring. Eggs are usually laid in deep-water nest chambers, where the female remains until the eggs hatch. In coastal popula-

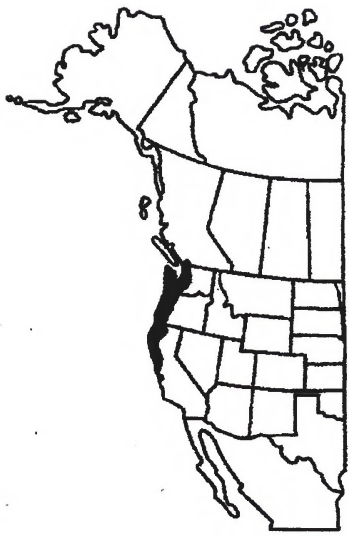
tions, eggs take about 200 days to hatch. The

Current range of the Pacific giant salamander 
clutch size is about 100 to 200 eggs. The larval period lasts two years in smaller streams, but in larger streams and lakes the salamanders can be neotenic.

Food: This salamander is an opportunistic carnivore. Adults eat land snails, slugs, insects, small mammals, other amphibians, lizards, and even birds. Aquatic larvae feed on insect larvae, tadpoles, other salamanders, and small fish.

Habits: It is found in humid mixed conifer and deciduous forests and riparian zones. Downed logs are required for shelter and foraging. Larvae occupy cold, clear water of streams, rivers, lakes, and ponds. Adults search for prey on the forest floor under ground debris, and have been known to climb trees in search of food.

Management Implications: The Pacific giant salamander was recently reclassified from $D$. ensatus to $D$. tenebrosus. It is common in suitable habitat. Activities causing siltation of streams and removal of riparian vegetation (which helps maintain cool water temperatures) are detrimental.

Important References: Stebbins, R.C. 1985. A field guide to western reptiles and amphibians. The Peterson Field Guide Series. Houghton Mifflin Company, New York, NY; Csuti, B., A.J. Kimerling, T.A. O'Neil, M.M. Shaughnessy, E.P. Gaines, and M.M.P. Huso. 1997. Atlas of Oregon wildlife. Oregon State University Press, Corvallis, OR. 


\section{Plains Leopard Frog}

\section{Rana blairi}

Family Ranidae

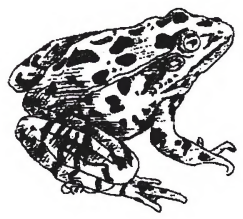

Global Rank: G5

State Rank: S1 (AZ); S3 (CO); S4 (NM)

Distribution: Ranges from southeastern South Dakota and western Iowa to eastern New Mexico and central Texas; eastern Colorado to central Indiana and central Oklahoma. It extends west in New Mexico along the Rio Bonito, Rio Hondo, and upper Rio Penasco to around 7,000 ft. $(2,130 \mathrm{~m}$.) near Sierra Blanca, Lincoln County, south along the Pecos River to near Carlsbad, Eddy County. Isolated populations on western side of the Chiricahua Mountains and adjoining Sulphur Springs Valley in southeastern Arizona, from about $350 \mathrm{ft}$. $(110 \mathrm{~m}$.) to $8,500 \mathrm{ft}$. $(2,590 \mathrm{~m}$.) in elevation.

Description: Adults range to $41 / 2$ in. (11 cm.) in snout-vent length. This generally palecolored leopard frog has light buffy brown to dull green above with brown to olive-green dorsal spots that lack or have very narrow pale borders. There is a whitish stripe on the upper

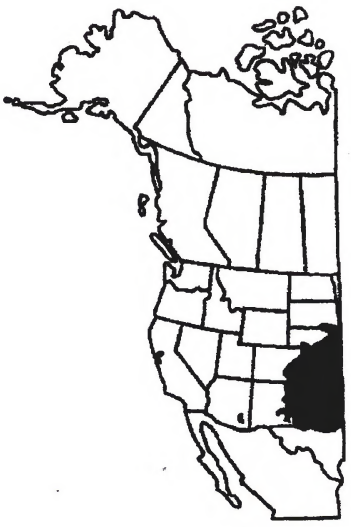
lip, and usually a well-defined pale spot in the center of the eardrum. Coloration below is white, sometimes with fine dark stippling or mottling on the throat. Some yellow may be present in the groin, on lower abdomen, and at 
base of thighs. Dorsolateral folds usually not continuous. Young have whitish upper lip stripes, often well defined. In adult males, the deflated vocal sacs tend to have lengthwise folds. Voice is usually 1-4 guttural, chucklelike notes lasting less than a second.

Reproductiou: Breeding occurs early February to early October. Eggs have been reported from March, May, and August, with tadpoles present late March to early June, and August to October. Large clutches of eggs are attached to vegetation in shallow water. Some tadpoles may overwinter.

Food: Probably feeds on a variety of insects and invertebrates. An individual was captured with a stomach full of grasshoppers and another contained a bat.

Habits: Found chiefly on the central and southern Great Plains, in prairie and desert grassland, but this frog also enters oak and oak-pine woodland and farmland. It frequents prairie pools, ponds, and streams (both permanent and temporary) where the water at times is muddy and shallow. It is more droughtresistant than the northern leopard frog. In the western states, it is found in streams, ponds, irrigation ditches, pools in rocky canyons, and rivers.

Management Implications: No known management concerns. Overlaps with the range of the Chiricahua leopard frog and the Rio Grande leopard frog, and may hybridize with them.

Important References: Stebbins, R.C. 1985. A field guide to western reptiles and amphibians. The Peterson Field Guide Series, Houghton Mifflin Company, New York, NY; Degenhardt, W.G., C.W. Painter, and A.H. Price. 1996. Amphibians and reptiles of New Mex- ico. University of New Mexico Press, Albuquerque, NM. 


\title{
Plains Spadefoot
}

\author{
Spea bombifrons \\ Family Pelobatidae
}

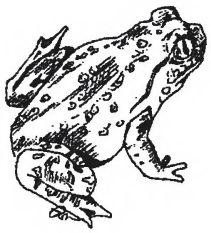

Global Rank: G5

State Rank: S2 (UT); S3 (AZ, MT);

S4 (WY); S5 (CO, NM)

Distribution: Found along the eastern and southern outwash of the Rocky Mountains from southern Alberta, Saskatchewan, and Manitoba in Canada south to northwestern Texas and Chihuahua, Mexico, east to Missouri and eastern Oklahoma. Skirts the Rockies to south and enters eastern Arizona, with isolated populations in southern Texas and Mexico. Reaches to about $8,000 \mathrm{ft}$. $(2,440 \mathrm{~m}$.) in elevation.

Description: Adults reach about $21 / 2$ in. (6.2 $\mathrm{cm}$.) in snout-vent length. They have a prominent boss between the eyes (often supported by thickened bone) and a pug-dog profile. There are usually four light stripes of irregular outline with the middle pair setting off a hourglass shape in the middle of the back. Coloration above is generally dusky, purplish brown, dark brown, or greenish, flecked with orange to yellow-tipped tubercles. Color below is white. A single glossy, black, wedge-shaped

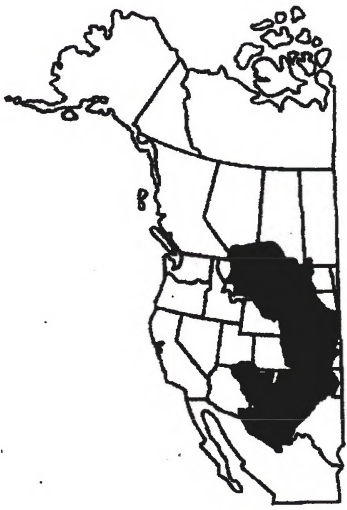
spade is on each hind foot. The width of the 
eyelids usually are greater than the distance between them.

Reproduction: They have opportunistic, relatively short, and high-density mating patterns, and are dependant upon heavy rainfall to stimulate reproductive activity. Usually breeds in flooded areas and temporary pools. The breeding period extends from May to August with peaks in July in most of its range. Numbers of eggs laid per female average about 1,600 (range 1,572-3,844) and they are attached to submerged vegetation or other objects in the water. Females may lay several egg masses during a single breeding event. Eggs hatch is two to three days. Larvae develop rapidly and commonly complete metamorphosis in 36 to 40 days. Young spadefoot toads breed the first time when about two years old.

Food: Adults feed mainly on various invertebrates, including adult moths, caterpillars, carabid beetles, and other small arthropods. There is one report of a spadefoot eating a small mouse. Larvae eat minute organic material, but sometimes prey on fairly large invertebrates such as fairy shrimp and insect larvae and other tadpoles. Such predatory larvae are larger and often metamorphose earlier than non-predatory larvae.

Habits: The plains spadefoot inhabits plains, hills, and river bottoms in mixed-grass prairie, sagebrush habitats, desert grassland, and farmland in areas of low rainfall. Prefers loose, sandy or gravelly soil that is suitable for burrowing. Frequents both permanent and temporary water sources. It digs its own burrow or uses rodent burrows. Rodents may attack the spadefoot or seal them off with soil plugs. Juveniles may hide in moist cracks or under plates of drying mud.
Management Implications: The genus was formerly known as Scaphiopus. Widespread and locally abundant within preferred habitat. Some populations have been lost to intensive agriculture and urban expansion, and many are killed by vehicles on roads near breeding ponds. It is known to interbreed with other spadefoot toads within its range.

Important References: Stebbins, R.C. 1985. A field guide to western reptiles and amphibians. The Peterson Field Guide Series. Houghton Mifflin Company, New York, NY; Degenhardt, W.G., C.W. Painter, and A.H. Price. 1996. Amphibians and reptiles of New Mexico. University of New Mexico Press, Albuquerque, NM; Hammerson, G.A. 1999. Amphibians and reptiles in Colorado. University of New Mexico Press, Albuquerque, NM. 


\section{Red-bellied Newt}

\section{Taricha rivularis \\ Family Salamandridae}

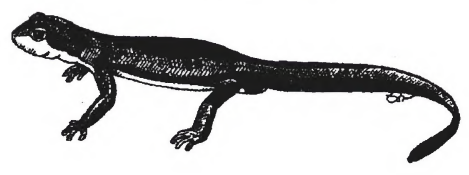

Global Rank: G4

\section{State Rank: S5 (CA)}

Distribution: Coastal region of California from the Russian River area, Sonoma County, and lower Lake and Kelsey Creeks, and north to Honeydew, Humboldt County.

Description: Range up to $31 / 4 \mathrm{in}$. $(8.1 \mathrm{~cm}$.) in snout-vent length. A dark-eyed newt, eyes are larger, head narrower, and snout longer than in other western species. Coloration is brown to nearly black above and tomato-red below. Dark color is conspicuous on undersides of the limbs. There is a prominent dark band across the vent, especially broad in males. There is less sex difference in skin texture than in other species.

Reproduction: Generally breeds in flowing water. They enter the water as early as the first week in February, and breed from late February to May in rivers and creeks.

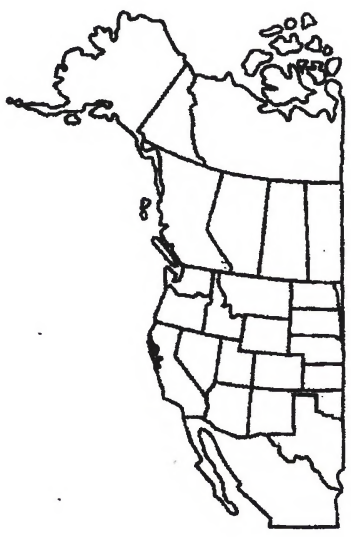

Food: Believed to be similar to other newts in that it eats earthworms, slugs, snails, insects, and amphibian eggs and larvae. 
Habits: A stream- or river-dwelling newt of coastal woodlands.

Management Implications: No known management concerns.

Important References: Stebbins, R.C. 1985. A field guide to western reptiles and amphibians. The Peterson Field Guide Series. Houghton Mifflin Company, New York, NY. 


\section{Red-legged Frog}

Rana aurora

Family Ranidae

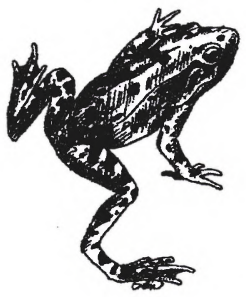

Global Rank: G4

State Rank: S2S3 (CA); S5 (WA);

SE (NV); SU (OR)

Distribution: Subspecies are the northern redlegged frog ( $R$. A. aurora) and the California red-legged frog ( $R$. A. draytonii). Extends chiefly west of the Cascade-Sierran crest from British Columbia (Sullivan Bay) to northwestem Baja California (Arroyo Santo Domingo). Apparently no longer found in Great Valley of California. Introduced into Nye County, Nevada. May now be extinct in the southern Sierra Nevada, California, because of habitat disturbance and introduction of bullfrog. From near sea level to around $8,000 \mathrm{ft} .(2,440 \mathrm{~m}$.) in elevation.

Description: Reaches to about $51 / 4$ in. (13.1 $\mathrm{cm}$.) in snout-vent length. Red occurs on the lower abdomen and underside of hind legs, often overlying yellow ground color. It usually has a dark mask bordered by a whitish jaw stripe. The back often has many small black flecks and larger irregular dark blotches with

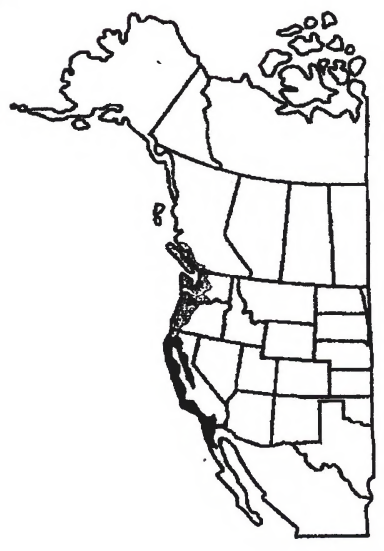

Current range of the red-legged frog (Northern and California) indistinct outlines on brown, gray, olive, or 
reddish ground color. Dark bands are on legs and there is usually a coarse black, red, and yellow mottling in groin area. Has relatively long legs with the heel of the adpressed hind limb extending to or beyond the nostril. Eyes are turned outward and are well-covered by lids. There are prominent dorsolateral folds. Young may have yellow instead of red on underside of legs and in groin. Adult males have enlarged forelimbs, thumb base, and webbing. The voice is a stuttering $u h-u h-u h-$ uh-uh-rowr lasting about 1-3 seconds, occasionally with chuckles, and sometimes given under water. During calling, the throat enlarges at center and at sides.

Reproduction: The breeding period is short (1-2 weeks), and may begin as early as February in lower elevations. About 2,000 eggs (range 750 to 4,000) are normally laid in pools of permanent, slow-moving water where they are attached to aquatic vegetation. Eggs hatch in about a month and tadpoles metamorphose about four months later. Sexual maturity is attained at three or four years of age.

Food: Adults eat invertebrates such as beetles, isopods, insect larvae, and other aquatic insects. Larvae eat aquatic algae and other organic debris.

Habits: This frog occurs in meadows, woodlands, and forests, but is usually found near ponds, marshes, and streams. It favors areas with dense ground cover and aquatic or overhanging vegetation. In non-breeding seasons, it occurs up to 300 yards from standing water. The home range is unknown and it is not thought to be territorial.

Management Implications: Heavily marketed in central California and elsewhere as source of frog legs in the late 1800 s and early 1900 s. Now absent from several parts of former range (southern Sierra Nevada and
Great Valley of California) due to habitat destruction and predation from the introduced bullfrog. Has special habitat requirement of quiet pools at least $3 \mathrm{ft}$. $(1 \mathrm{~m}$.) deep in permanent streams. Known to have had serious declines in recent years in the Willamette Valley of Oregon. It was formerly a federal candidate species.

Important References: Stebbins, R.C. 1985. A field guide to western reptiles and amphibians. The Peterson Field Guide Series. Houghton Mifflin Company, New York, NY; Csuti, B., A.J. Kimerling, T.A. O'Neil, M.M. Shaughnessy, E.P. Gaines, and M.M.P. Huso. 1997. Atlas of Oregon wildlife. Oregon State University Press, Corvallis, OR; Verner, J. and A.S. Boss. 1980. California wildlife and their habitats: western Sierra Nevada. USDA Pacific Southwest Forest and Range Experiment, GTR PSW-37, Berkeley, CA. 


\section{Red-spotted Toad}

Bufo punctatus

Family Bufonidae

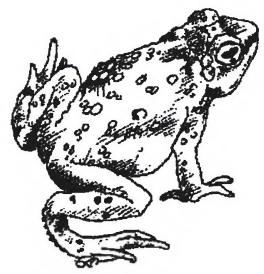

Global Rank: G5

State Rank: S3 (UT); S4 (CO); S5 (AZ, CA, NV, NM)

Distribution: It ranges from southern Nevada to southwestern Kansas to Hidalgo and the tip of Baja Califormia in Mexico, and from central Texas to southeastern California. Extends from below sea level at Death Valley, California, to around $6,500 \mathrm{ft}$. $(1,980 \mathrm{~m}$.) in elevation.

Description: Adults reach to 3 in. $(7.5 \mathrm{~cm}$.) in snout-vent length. This small toad has a flattened head and body and round paratoids, each about the same size as the eye. The snout is pointed, and cranial crests are weak or absent. Coloration is light gray, olive, or reddish brown above, with reddish or orange warts. It is whitish to buff below, with or without spotting. Young have numerous red- or orange-tipped warts, and are dark spotted below. Underside of feet are yellow. Adult males have dusky throats.

Reproduction: Breeds from March to Sep-

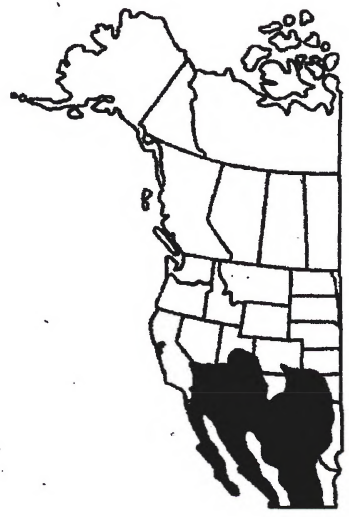

Current range of the red spotted toad tember during or after rains in springs, rain 
pools, reservoirs, and temporary pools in intermittent streams. May be diurnal during breeding season. Males generally call from exposed boulders or rocks at the water's edge. Small choruses of fewer than ten males are more common. The eggs of this toad are the most distinctive of all North American toads. Eggs are laid singly instead of in strings. Each egg is protected by a layer of sticky gelatin that adheres together to form egg masses a single layer thick. Hatching and metamorphorsis of tadpoles usually occurs quickly during the late spring and summer.

Food: Diet includes beetles, bees, bugs, ants, and various other arthropods. One study found that adults generally had empty stomachs in May and June, but whether this was related to the breeding season, the emergence of prey species related to the normal July rainy season, or other reasons is unknown.

Habits: The toad is most often encountered in dry rocky areas at lower elevations, where it typically occurs near desert springs, persistent pools, along rocky arroyos, or around cattle tanks. At higher elevations, it utilizes open grassland, scrubland, oak woodland, and rocky canyons. The toad's small size and relatively flat shape probably helps it retreat under rocks or into rock crevices during dry weather. It is largely nocturnal except during the breeding season, but occasionally may be found abroad during mornings and early evenings. It is active and alert and is often found under large flat rocks where it seeks shelter during the day. It is often found on roadways at night during summer rains. It climbs trees with ease.

Management Implications: No known management problems. Little is known about its life history. It may interbreed with the western toad and Woodhouse's toad in parts of its range.
Important References: Stebbins, R.C. 1985. A field guide to western reptiles and amphibians. The Peterson Field Guide Series. Houghton Mifflin Company, New York, NY; Degenhardt, W.G., C.W. Painter, and A.H. Price. 1996. Amphibians and reptiles of New Mexico. University of New Mexico Press, Albuquerque, NM. 


\title{
Relictual Slender Salamander
}

\author{
Batrachoseps relictus \\ Family Plethodontidae
}

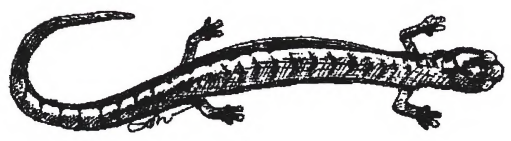

Global Rank: G2

State Rank: S2? (CA)

Distribution: Range is fragmented within the southern Sierra Nevada of California from the Merced River Canyon, Tuolumne County, south. Reaches from near sea level to about $8,000 \mathrm{ft}$. $(2,440 \mathrm{~m}$.) in elevation. Classification and distribution of several central California slender salamanders is still being studied. For this report, the relictual slender salamander is substituted for the Pacific slender salamander referred to in Stebbins (1985).

Description: Adults reach up to $23 / 4$ in. (6.9 $\mathrm{cm}$.) in snout-vent length. The species "group" varies widely in size, proportions, and coloration. There is no known overall structural or color characteristic or group of characteristics that will distinguish this species from other slender salamanders in the region. Overall, there are 16 to 21 costal grooves, $51 / 2$ to 13 costal folds between toes of adpressed limbs, and tails vary from less than to about two times the snout-vent length.

Reproduction: Breeding habits largely un-

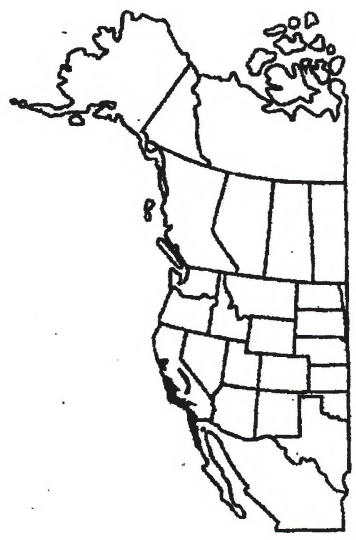

known. Eggs are laid in moist places under

Current range of the relictual slender salamander 
surface objects from May to July. Peak activity probably is in June. Mean clutch size is 4 (range 1 to 12).

Food: Feeds on small insects and other invertebrates which it searches for under surface objects.

Habits: Prefers mountain meadows, but also found in ponderosa pine, black oak woodland, riparian deciduous, and mixed-conifer types. Also has been found in grassland and chaparral types and along washes, in salt marshes, and under beach driftwood.

Management Implications: Common in preferred habitat. First described in 1968, and little information on life history is known. Not thought to be territorial. Home ranges suspected to be about a half acre.

Important References: Stebbins, R.C. 1985. A field guide to western reptiles and amphibians. The Peterson Field Guide Series. Houghton Mifflin Company, New York, NY; Verner, J., and A.S, Boss. 1980. California wildlife and their habitats: western Sierra Nevada. USDA Pacific Southwest Forest and Range Experiment Station, GTR PSW-37, Berkeley, CA. 


\section{Rio Grande Frog}

\section{Rana berlandieri \\ Family Ranidae}

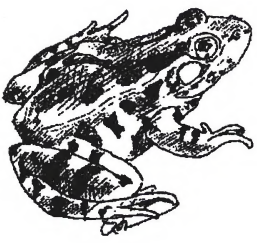

Global Rank: G5

State Rank: SE3SE4 (AZ); S3 (NM)

Distribution: Known from extreme southern New Mexico (Pecos River drainage), central and western Texas into Mexico. Has been introduced into the lower Colorado and Gila Rivers in Arizona. Found between 2,950 ft. $(900 \mathrm{~m}$.) and 5,000 ft. (1,500 m.) in elevation.

Description: Adults reach up to $41 / 2$ in. $(11.2 \mathrm{~cm}$.) in snout-vent length. It resembles the northern leopard frog, but generally much paler above, varying from grayish brown, brownish olive, to green or even blue-green. Dorsal spots are lighter and less clearly edged with light color. Dorsolateral folds segmented in front of groin and deflected inward. The eyes are wide. A wide, light-colored jaw stripe fades or is absent in front of eye. Often dusky below, especially on chest and throat where the dark pigment is mottled. Groin and underside of hind limbs often yellow. Adult males have swollen and darkened thumb base.

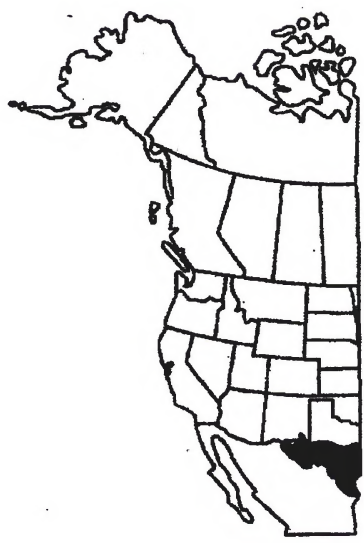

Reproduction: The breeding season extends from spring through fall, with a peak activity during April. Adult frogs have been heard call- 
ing between April and August. Egg masses have been found from mid-April through early. July, and were attached to emergent vegetation in deep, quiet water along streams. Tadpoles may overwinter.

Food: Food habits unknown, but probably feeds on a variety of insects and invertebrates.

Habits: Frequents streams, rivers and their side pools, springs, pools along arroyos, and stock ponds within grassland and woodland types. May disperse during wet periods. A key habitat component is the presence of holes or burrows that metamorphosed frogs can utilize for refugia.

Management Implications: Within the western states, known only from extreme southern New Mexico (Pecos River drainage) and where it has been introduced into the lower Colorado and Gila Rivers of Arizona..

Important References: Stebbins, R.C. 1985. A field guide to western reptiles and amphibians. The Peterson Field Guide Series. Houghton Mifflin Company, New York, NY; Degenhardt, W.G., C.W. Painter, and A.H. Price. 1996. Amphibians and reptiles of New Mexico. University of New Mexico Press, Albuquerque, NM. 


\section{Roughskin Newt}

\section{Taricha granulosa}

Family Salamandridae

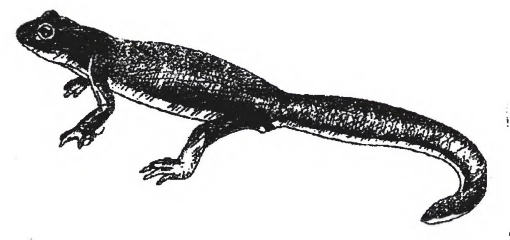

Global Rank: G5

State Rank: S2 (AK); S5 (CA, OR, WA); SE (ID); SE1 (MT)

Distribution: Found from the coastal mountains and lowlands of southeast Alaska south to Santa Cruz County, California. Also found in the Cascade Mountains of Washington, Oregon, and northern California. It is known from a number of ponds in the Moscow, Idaho, area, where it was probably introduced. It is also commonly called the roughskinned newt.

Description: Adults reach up to 7.9 in. (20 $\mathrm{cm}$.) in total length. Key characteristics are rough skin, usually brown dorsal coloration and yellowish-orange ventral coloration. Some populations have dark blotches or are all dark on ventral surface. Breeding males (pictured) develop smooth skin, brown to olive coloration above and a broad dusky patch on each side, a bulbous vent, flattened tail, and dark

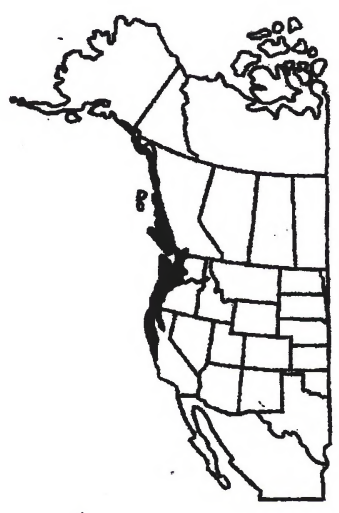
skin on underside of feet. In some parts of its range, the roughskin newt curls the tip of its tail in a defensive pose. Larvae reach up to 3 in. $(7.5 \mathrm{~cm}$.) in total length. Key characteristics are greenish-yellow dorsal surface with light
Current range of the roughskin newt 
spots along sides and pink or orange ventral surface. Eyes appear along outer margin of head when viewed from above.

Reproduction: Roughskin newts breed from December to July, beginning earlier at the lower elevations. It differs from other western newts in laying eggs singly. Up to 30 eggs are laid and attached to vegetation or other objects. Eggs hatch in 20-26 days and metamorphose before winter. Sexual maturity is reached at 3-4 years of age.

Food: Adult roughskin newts eat earthworms, slugs, snails, and insect larvae, as well as amphibian eggs and tadpoles. Larvae feed on zooplankton and small aquatic invertebrates.

Habits: The newt occurs in a wide variety of habitats, from grasslands to conifers and mixed forests. It requires ponds, reservoirs, lakes, or slowly flowing streams for breeding and is usually found near a source of water. It hides under rocks, bark, or logs, but is often seen moving about in the daylight. It can migrate considerable distances to breeding ponds and can be very abundant in appropriate habitat. The main predator seems to be common garter snakes. The average life span is 12 years, but individuals may live up to 26 years.

Management Implications: The roughskin newt has poisonous skin secretions which repel most predators. The toxin (tetrodotoxin) can be fatal to humans and is chemically identical to the toxin found in puffer fish (such as the fugu fish of Japan) which has been responsible for many human deaths.

Important References: Stebbins, R.C. 1985. A field guide to western reptiles and amphibians. The Peterson Field Guide Series, Houghton Mifflin Company, New York, N.Y; Csuti, B., A.J. Kimerling, T.A. O'Neil, M.M. Shaughnessy, E.P. Gaines, and M.M.P. Huso.
1997. Atlas of Oregon wildlife. Oregon State University Press, Corvallis, OR. 


\section{Sacramento Mountain Salamander}

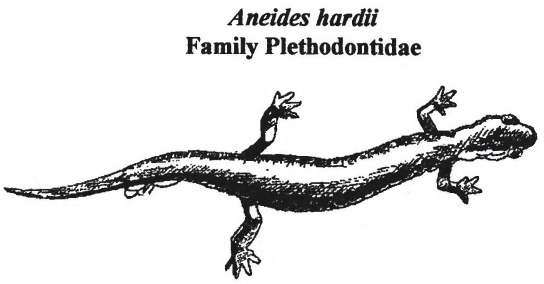

Global Rank: G3

State Rank: S3 (NM)

Distribution: Isolated to the Sacramento, White, and Capitan Mountains of south-central New Mexico. The range extends from around $8,500 \mathrm{ft}$. $(2,600 \mathrm{~m}$.) to $11,700 \mathrm{ft}$. $(3,600 \mathrm{~m}$.) in elevation.

Description: Adults reach about 3 in. (7.5 $\mathrm{cm}$.) in snout-vent length. Tails are normally slightly shorter than the body length. The salamander is slim bodied, short-legged, agile, and an excellent climber. It has 14 to 15 costal groves and 2 to $41 / 2$ costal folds between the tips of the toes of adpressed limbs. Toe tips are rounded. Coloration is light to dark brown above, with varying amounts of greenish gray to bronze mottling. The belly is light brown, throat is cream-colored, and underside of tail is slate. Young have a whitish throat and a brown or bronze dorsal stripe.

Reproduction: Mature males are slightly larger than females. Both sexes reach maturity in two years, but the females require an additional year before ova reach sufficient size for

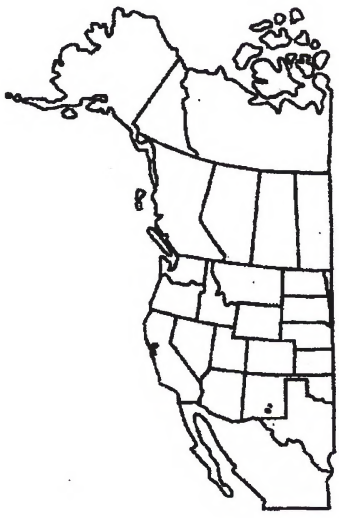

Current range of the Sacramento Mountain salamander 
oviposition. Oviposition occurs every three years thereafter. Average number of eggs is ten, probably the smallest number among salamanders. Eggs are deposited in large, moist, decomposing Douglas-fir logs or log cavities in July through September. The eggs are guarded by the females. Juveniles believed to be newly hatched have been found under bark from mid-June through September.

Food: Feeds on various arthropods and other invertebrates, including annelid worms, mollusks, collembolans, beetles, ants, and small wasps. About 40 percent of the diet is ants and 30 percent is beetles.

Habits: The salamander is generally associated with Douglas-fir and spruce forests where there is usually large woody debris or rocks.

Management Implications: The salamander is locally abundant where the essential microhabitat characteristics are available.

Important References: Stebbins, R.C. 1985. A field guide to western reptiles and amphibians. The Peterson Field Guide Series. Houghton Mifflin Company, New York, NY; Degenhardt, W.G., C.W. Painter, and A.H. Price. 1996. Amphibians and reptiles of New Mexico. University of New Mexico Press, Albuquerque, NM. 


\section{Shasta Salamander}

\section{Hydromantes shastae}

Family Plethodontidae

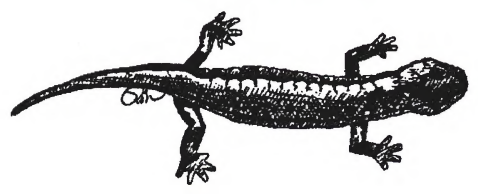

Global Rank: G1G2

State Rank: S1S2 (CA)

Distribution: Known only from limestone country in northern California south of Mount Shasta in the headwaters of Shasta ReservoirBackbone Ridge, Mammoth Ridge, Hirz Mountain, and adjacent areas of Shasta County. Ranges from about $1,000 \mathrm{ft}$. (300 m.) to $3,000 \mathrm{ft}$. $(910 \mathrm{~m}$.) in elevation.

Description: Adults reach up to $21 / 2$ in. (8.7 $\mathrm{cm}$.) in snout-vent length. The body is less flat, toes less webbed, and limbs longer than similar salamanders more developed for crevice living. Adpressed limbs overlap by $1 / 2$ to $11 / 2$ costal folds. Coloration is gray-green, beige, $\tan$, or reddish above, usually with yellow on the tail. There are white blotches on the chest and abdomen. Young are gray-green, olive, tan, or reddish on upper body, and yellowish above on the tail.

Reproduction: Probably breeds from May to July, with peak breeding in June. Mean clutch size is 7 eggs (range 5 to 12). It is thought to breed and to lay and brood eggs in moist

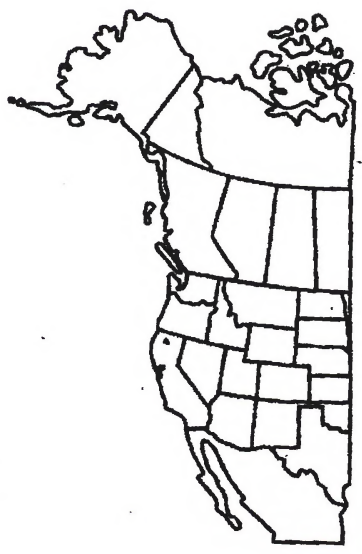
caverns. 
Food: Diet is insects and other invertebrates which it searches for under surface objects and in caverns.

Habits: Primarily a cave dweller and less specialized for crevice dwelling than similar salamanders. Restricted in distribution to limestone outcrops and caverns, but may be found under rocks in the open during wet weather. Found in all successional stages of digger pine-oak, ponderosa pine, and black oak types. It enters moist caves in the summer. Not thought to be territorial. The home range may be up to one acre.

Management Implications: Rare due to limited habitat. Has a special habitat requirement for moist limestone outcrops and caverns.

Important References: Stebbins, R.C. 1985. A field guide to western reptiles and amphibians. The Peterson Field Guide Series. Houghton Mifflin Company, New York, NY; Verner, J., and A.S. Boss. 1980. California wildlife and their habitats: western Sierra Nevada. USDA Pacific Southwest Forest and Range Experiment Station, GTR PSW-37, Berkeley, CA. 


\section{Sonoran Desert Toad}

\section{Bufo alvarius}

Family Bufonidae

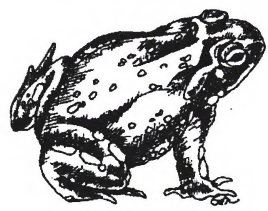

Global Rank: G5

State Rank: S1 (CA); S2 (NM); S5 (AZ)

Distribution: Also known as the Colorado River toad. Extends from the Bill Williams River and the lower Colorado River drainages across southern Arizona to extreme southwestern New Mexico, south to northwestern Sinaloa in Mexico, to extreme southeastern California. It reaches from sea level to 5,300 $\mathrm{ft} .(1,610 \mathrm{~m}$.) in elevation.

Description: This is the largest of the western toads, and adults reach around $71 / 2$ in. (19 $\mathrm{cm}$.) in snout-vent length. Coloration is dark brown, olive, or gray above, with smooth skin. It has long, kidney-shaped parotoids and prominent cranial crests. There are several large warts on the hind legs which stand out conspicuously against the smooth skin. An enlarged whitish wart is near the angle of the jaw. Coloration below is cream. Young have light-colored warts set in dark spots. Both

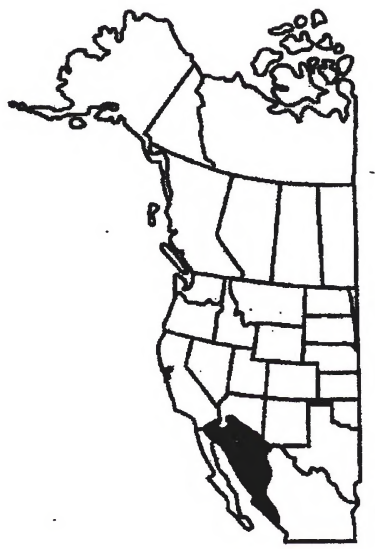
males and females have pale throats. The voice is weak, low-pitched, and resembles a ferryboat whistle. The vocal sac is missing or vestigial.

Current range of the Sonoran Desert toad 
Reproduction: Breeding activity usually starts the night after a heavy spring or summer rain, although breeding is not dependent upon rains. Some males search for females while others call from shoreline sites or in very shallow water. Calling males are usually larger than searching males. Aggregations of about 200 toads have been observed in July. Eggs are laid in long, jelly-coated strings, and may number several thousand eggs per string. While the larval stage may be short, no longer than a month, the breeding season may be quite long.

Food: Diet normally includes beetles, ants, termites, and solpugids. It has been known to also eat snails, grasshoppers, spiders, centipedes, millipedes, wasps, lizards, mice, and amphibians. It apparently will prey on anything it can overcome, regardless of protection by sting-mechanisms or defensive secretions.

Habits: Ranges from arid mesquite-creosote bush lowlands and arid grasslands into the oak-sycamore-walnut communities in mountain canyons. It enters tropical thorn forests in Mexico. Often found near permanent water of springs, reservoirs, canals, and streams, but also frequents temporary pools and has been reported several miles from water. It is nocturnal and widespread through the desert. It is rarely seen except during the breeding season when it may be found on roadways or around permanent or temporary water sources. Much of its time is spent below ground in rodent burrows or near water where the humidity is high.

Management Implications: Listed as endangered by the New Mexico Department of Game and Fish. Skin toxins may paralyze or kill dogs and are a potent hallucinogen. The toad is one of the least known of the North American toads.
Important References: Stebbins, R.C. 1985. A field guide to western reptiles and amphibians. The Peterson Field Guide Series. Houghton Mifflin Company, New York, NY; Degenhardt, W.G., C.W. Painter, and A.H. Price. 1996. Amphibians and reptiles of New Mexico. University of New Mexico Press, Albuquerque, NM. 


\title{
Sonoran Green Toad
}

\author{
Bufo retiformis
}

Family Bufonidae

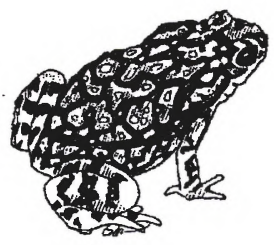

Global Rank: G3G4

State Rank: S3 (AZ)

Distribution: Restricted from south-central Arizona south to west-central Sonora, Mexico. In southern Arizona, it is known from the Santa Rosa Wash in Pinal County, and the Organ Pipe Cactus National Monument to the vicinity of the San Xavier Mission in Pima County.

Description: Adults reach about $21 / 2$ in. (5.6 $\mathrm{cm}$.) in snout-vent length. Similar to the green toad, except that it is vividly marked above with a network of black or brownish that sets off oval areas of greenish yellow ground color. These oval areas are about twice the size of those on green toads of similar size. Adult males have dark throats.

Reproduction: Breeds from July to August in rainwater sumps and wash bottoms. Males begin to call at nightfall after summer rains, usually from grassy areas or within a foot or so of the water's edge. Due to the temporary nature of the water, the eggs are believed to hatch quickly and tadpoles quickly go through

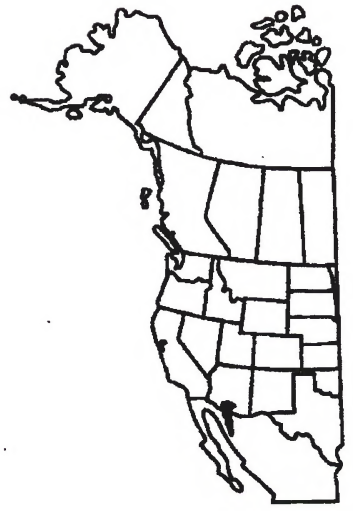

Current range of the Sonoran green toad 
metamorphosis.

Food: Believed to eat a large variety of insects and other invertebrates, including ants, beetles, and moths.

Habits: A secretive, nocturnal species of mesquite grassland and creosote bush desert. They seek shelter underground in burrows or under surface objects such as rocks and dry cattle dung. They are not usually seen except during the breeding season.

Management Implications: Limited range, but no known management concerns.

Important References: Stebbins, R.C. 1985. A field guide to western reptiles and amphibians. The Peterson Field Guide Series. Houghton Mifflin Company, New York, NY. 


\title{
Southern Spadefoot
}

\author{
Spea multiplicatus
}

Family Pelobatidae

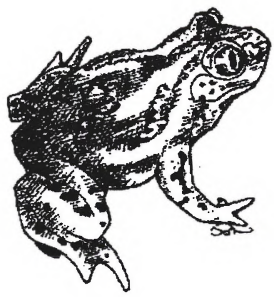

Global Rank: G5

State Rank: S2 (UT); S4 (CO); S5 (AZ, NM)

Distribution: Also known as the New Mexico spadefoot, this species was formerly known by the genus Scaphiopus. It ranges from southeastern Utah and southern Colorado south to Guerrero and Oaxaca, Mexico, and from western Arizona to western Oklahoma and western Texas. It can be found from near sea level to around $8,100 \mathrm{ft}$. $(2,470 \mathrm{~m}$.) in elevation.

Description: Adults reach about $21 / 2$ in. (6.4 $\mathrm{cm}$.) in snout-vent length. They closely resemble the western spadefoot and differ in having a more elongated spade, usually more brown on the back, and having copper-colored irises. They lack a boss between the eyes, the eyelids are wider than the space between them, and the dorsal color is uniformly brown or dark gray with small dark spots or blotches and redtipped tubercles scattered over the dorsum. The call is a vibrant, metallic trill, like run-

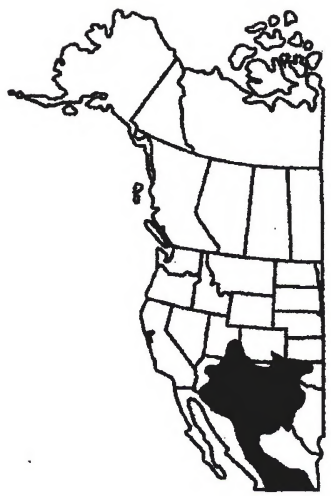

Current range of the southern spadefoot 
ning a fingernail along the teeth of a large comb.

Reproduction: Breeds during periods of summer rains that fill playa lakes and cause the rapid formation of pools in low-lying areas. A delay in the desert July monsoons during dry years may cause the toad to not breed until late in the season. Males usually call while floating on the water surface. Females average about 1,070 eggs, which are deposited in cylindrical masses attached to submerged aquatic vegetation or debris. Eggs hatch in about 42 to 48 hours and tadpoles undergo metamophosis in about three weeks. Toadlets emerge from the drying ponds and disperse.

Food: A study of the stomach contents of 293 spadefoot toads found that 93.8 percent of the diet consisted of beetles, orthopterans, ants, spiders, and termites. No difference in diet was found due to sex or time of year. Another study found that the diet was 72 percent termites and 22 percent beetles, with an occasional centipede and scorpion. Arthropods with well-known chemical defenses, such as blister beetles, velvet ants, stink bugs, and millipedes, are usually avoided. Tadpoles are known to eat tadpole shrimp, fairy shrimp, and other tadpoles.

Habits: Frequents desert grassland, shortgrass plains, creosote bush and sagebrush deserts, mixed grassland and chaparral, pinon-juniper and pine-oak woodlands, and open pine forests. Soils are often sandy or gravelly. The spadefoot is largely nocturnal and secretive. They occupy underground burrows that are dug with their specialized hind feet. During the summer rainy season, they can be found hidden under surface objects. During nocturnal wanderings in search of prey or breeding sites, the spadefoot can often be seen on roadways.
Management Implications: No known management concerns. When molested, these toads may secrete a musty skin toxin that smells somewhat like raw peanuts which can irritate sensitive membranes of the eyes and nose.

Important References: Stebbins, R.C. 1985. A field guide to western reptiles and amphibians. The Peterson Field Guide Series. Houghton Mifflin Company, New York, NY; Degenhardt, W.G., C.W. Painter, and A.H. Price. 1996. Amphibians and reptiles of New Mexico. University of New Mexico Press, Albuquerque, NM. 


\section{Southwestern Toad}

\section{Bufo microscaphus}

Family Bufonidae

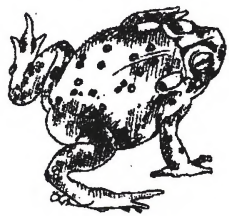

Global Rank: G3G4

State Rank: S1S2 (NV); S2 (NM, UT); S3S4 (AZ)

Distribution: Isolated populations from southern Nevada to southern Durango, Mexico; and coastal southern California to northwestern Baja California. The southern California/Baja California populations are considered by some to be a separate species, the arroyo toad (Bufo californicus). Common along the rivers and lakes of the Gila and San Francisco River drainages. From near sea level to around $6,000 \mathrm{ft} .(1,830 \mathrm{~m}$. $)$ in elevation.

Description: Adults reach to about $31 / 4 \mathrm{in}$. $(8.1 \mathrm{~cm}$.) in snout-vent length. They are a rather uniformly warty, stocky toad with a light-colored stripe across the head, including the eyelids. The parotoid glands are ovalshaped, widely separated, and pale towards the front. Color above is greenish gray, buff, brown, or salmon. The color harmonizes with the general color of the soil and rocks. There usually is a light area on each sacral hump and in middle of the back. Color is buff below and often unspotted. Cranial crests are weak or absent. Young are ash-white, light olive, or

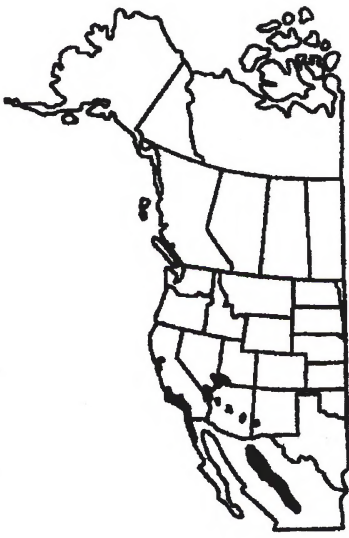

Current range of the southwestern toad 
salmon above, with or without prominent black spots, and have red-tipped tubercles on the back. Undersides of feet are yellow. In adults, both males and females have pale throats. The voice is a melodious trill, lasting up to 10 seconds. The vocal sac is round.

Reproduction: Breeds from March through July. They are not dependent upon spring or summer rains to initiate breeding, probably because they normally breed at permanent water sources. The photoperiod and temperature may be more important in stimulating breeding activity. Gravid females have been found in early April, calling and egg laying as early as February 7 , and mature tadpoles found in late May through July. Eggs are laid in long strings with up to 3,000 to 4,300 eggs per string.

Food: The diet is believed to include a wide variety of small arthropods, including true bugs, beetles, and moths. Specimens from Utah contained a sand cricket, several beetles, a true bug, ants, bees, moth larvae, snails, and plant fragments.

Habits: This is a toad of washes, streams, and arroyos in semiarid parts of the Southwest. It frequents sandy banks grown to willows, cottonwoods, or sycamores, and along rocky streams in the pine-oak belt. It is usually associated with permanent ponds or rocky streams with relatively shallow water over sandy or rocky bottoms, and it rarely moves away from watered sources.

Management Implications: Found in a series of isolated populations. Common is most locations in central Arizona, but may be rare in Nevada, New Mexico, and Utah. The California subspecies may also be rare; it is considered by some as a separate species, the arroyo toad (Bufo californicus).
Important References: Stebbins, R.C. 1985. A field guide to western reptiles and amphibians. The Peterson Field Guide Series. Houghton Mifflin Company, New York, NY; Degenhardt, W.G., C.W. Painter, and A.H. Price. 1996. Amphibians and reptiles of New Mexico. University of New Mexico Press, Albuquerque, NM. 


\section{Striped Chorus Frog}

\section{Pseudacris triseriata \\ Family Hylidae}

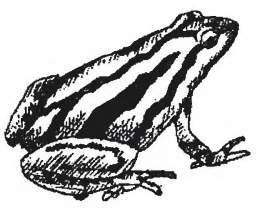

Global Rank: G5

State Rank: S5 (AZ, CO, MT, NM, WY)

Distribution: Found from Great Bear Lake in Canada southeast to the Gulf of Mexico and most of the United States east of the Rocky Mountains. In the West, it occurs in most of Alberta, Montana, Wyoming, and Colorado, with extensions into Idaho, Utah, New Mexico, and Arizona. The boreal chorus frog (p.t. maculata) is the subspecies which occurs is most western states, and the midland chorus frog (p.t. triseriata) is the subspecies found in central Arizona and New Mexico. Throughout its range, it occurs in a wide variety of habitat types from deserts to above timberline.

Description: Adult frogs reach up to $1.5 \mathrm{in}$. $(3.8 \mathrm{~cm}$.) in snout-vent length. Key characteristics include long toes, small toe pads, limited webbing, usually three dark stripes or rows of spots on back, and a pointed snout. Coloration varies from green to brown, and they can

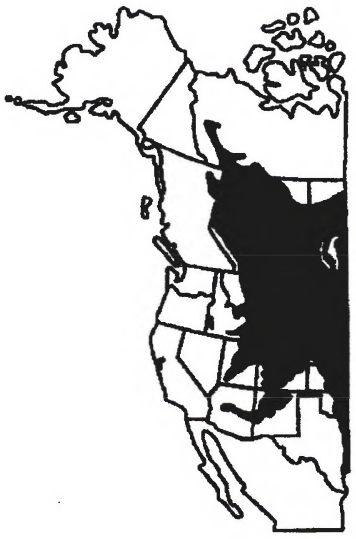
lighten or darken their shading. Tadpoles reach up to 1.2 in. $(3 \mathrm{~cm}$.) total length. Key characteristics are eyes laterally placed, projecting beyond the margin of the head when viewed Current range of the striped chorus frog from above; coloration brown dorsally and 
white ventrally; dorsal fin arched; and intestines visible. Adult males have greenish yellow to dark olive throats with lengthwise folds of loose skin, and a round vocal sac. The voice is a loud, low-pitched walk, walk, walk at the same pitch.

Reproduction: Congregations of singing males initiate breeding season with loud distinctive calls. Choruses occur night and day during the height of the breeding season, and may continue from March to as late as August. Up to 1,500 eggs per clutch, laid in clusters of from 20 to 100 eggs are laid and glued to submerged vegetation. Larvae metamorphose in about two months and they become sexually mature after one to three years, depending upon elevation.

Food: Adult frogs eat a variety of small terrestrial arthropods. The larval forms of the striped chorus frog eat suspended matter, organic debris, algae, and plant tissue.

Habits: The frogs inhabit marshes, ponds, and small lakes in all life zones including lower elevations of the alpine zone, and are rarely found far from permanent water. While they can climb vertical surfaces using the suction cups on its toes, the striped chorus frog does not live in trees. They can hibernate or aestivate to escape adverse temperatures. When inactive, they hide in water, thick vegetation, under objects on the ground, or in rodent burrows. Local populations may include a few dozen adults or as many as tens of thousands of individuals. Tadpoles are preyed upon by garter snakes and tiger salamander larvae.

Management Implications: The population status throughout nearly all of its range is considered common. The frogs adapt well to human habitation, occurring on farms and in cities except in areas where pesticides have been used heavily.

Important References: Stebbins, R.C. 1985. A field guide to western reptiles and amphibians. The Peterson Field Guide Series, Houghton Mifflin Company, New York, NY; Baxter, G.T., and M.D. Stone. 1980. Amphibians and reptiles of Wyoming. Wyoming Game and Fish Department, Cheyenne, WY; Groves, C.R., B. Butterfield, A. Lippincott, B. Csuti, and J.M. Scott. 1997. Atlas of Idaho's wildlife. Idaho Department of Fish and Game, Boise, ID. 


\section{Tailed Frog}

\section{Ascaphus truei}

Family Ascaphidae

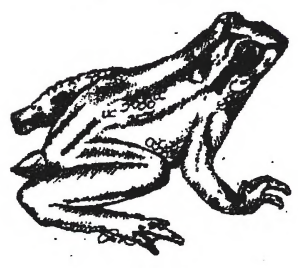

Global Rank: G4

State Rank: S3 (ID, OR); S4 (MT, WA); S2S3 (CA)

Distribution: Found in forested coastal and interior mountains of the Northwest from southern British Columbia to northern California, the Blue Mountains of Oregon, and the Rocky Mountains of Idaho and western Montana. Some herpetologists believe that the Rocky Mountain and Northwest populations may be different species. They are found from sea level to over $6,500 \mathrm{ft}$. $(2,000 \mathrm{~m}$.) in clear, cold, swift-moving mountain streams.

Description: Adult tailed frogs reach up to 2 in. $(5 \mathrm{~cm}$.) in snout-vent length. Key characteristics are no tympanic membrane (eardrum); the fifth toes on hindfeet are wider than others; pupils are vertical; skin is smooth to warty; and dorsal coloration can vary (yellow, gray, brown, or reddish). Mature males develop "tail." Tadpoles reach up to 2.4 in. $(6 \mathrm{~cm}$.) in

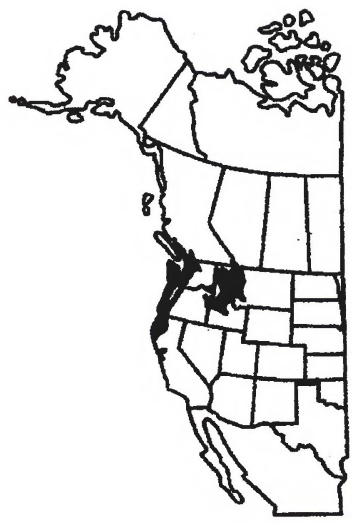
total length and have a distinctive sucker-like mouth which allows them to attach to smooth rocks in well-oxygenated parts of streams. Tadpoles usually have a white spot on the tip

Current range of the tailed frog 
of the tail, and coloration may vary (black, brown or $\tan$ ), and may be uniformly colored or mottled.

Reproduction: Adults may not breed until 78 years of age, or 6-8 years after metamorphosis. Breeding occurs from May through late summer. They have no known voice. Fertilization is internal; male has tail-like copulatory organ. Eggs are laid in a string/cluster on the underside of rocks. Clutch size varies from 30 to nearly 100 eggs which are laid in July and hatch from August through September. Larvae metamorphize to adults in June to September after up to three years, depending on elevations and water temperatures.

Food: Adults eat a wide variety of insects and other invertebrates. Larvae mainly feed on diatoms, algae, and pollen.

Habits: Tailed frogs are restricted to cold, fast-flowing permanent streams, normally in forests. They are not found in lakes or ponds. Adults are most active from April through October, depending on locality. Adults emerge at night and may forage as far as $75 \mathrm{ft}$. (22 m.) from streams during moist weather. They remain on stream banks during dry weather.

Management Implications: Tailed frogs are indicator species for headwater streams in good condition (shade, cold water temperatures, high oxygen levels). They are known to decline after logging, loss of riparian vegetation, or other disturbances in these streams which increase water temperatures and sedimentation. Since tailed frogs are not known to migrate cross-country to other streams, metapopulations are easily lost and difficult to reestablish.

Important References: Stebbins, R.C. 1985. A field guide to western reptiles and amphibians. The Peterson Field Guide Series, Hought- on Mifflin Company, New York, NY; Csuti, B., A.J. Kimerling, T.A. O'Neil, M.M. Shaughnessy, E.P. Gaines, and M.M.P. Huso. 1997. Atlas of Oregon wildlife. Oregon State University Press, Corvallis, OR; Groves, C.R., B. Butterfield, A. Lippincott, B. Csuti, and J.M. Scott. 1997. Atlas of Idaho's wildlife. Idaho Department of Fish and Game, Boise, ID. 


\section{Tarahumara Frog}

\section{Rana tarahumarae}

Family Ranidae

Global Rank: G3

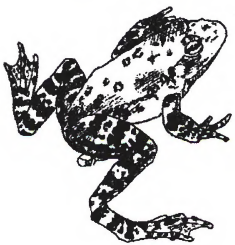

State Rank: SX (AZ)

Distribution: Known from the Pajarito, Tumacacori, and Santa Rita Mountains of south-central Arizona (extremely rare or extinct). South in Sierra Madre Occidental to Sinaloa, Mexico. Ranges from about $1,500 \mathrm{ft}$. $(460 \mathrm{~m}$.) to $6,100 \mathrm{ft}$. $(1,800 \mathrm{~m}$.) in elevation.

Description: Reaches to $41 / 2$ in. $(10.6 \mathrm{~cm}$.) in snout-vent length. Coloration is rust, olive, or dark brown above, with dark spots that often have light centers. Prominent dark banding on the hind legs. White to cream coloration below, often clouded with dusky. No mask or light jaw stripe. The dorsolateral folds and eardrums indistinct, with the eardrum frequently granular. Adult males have a swollen and darkened thumb base.

Reproduction: In Arizona, known to breed in July through August, during the period of summer rains.

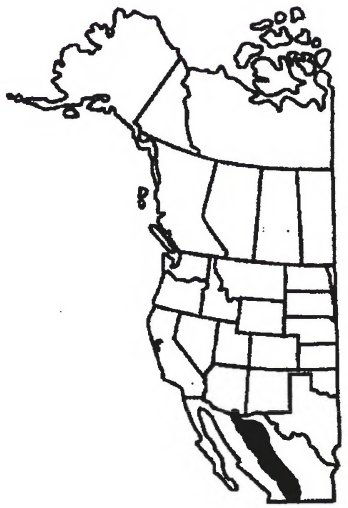

Food: Diet is unknown, except that the frog probably eats a wide variety of insects and invertebrates. 
Habits: A species of the Sierra Madre Occidental, barely entering the United States in the mountains of extreme southern Arizona. Ranges from oak woodland into pine forests, along rocky, gravely stream courses. This "plunge pool" frog is usually found within a jump or two of water, on the banks of pools, under stones, in niches in cliffs, or sitting in riffles. While it apparently prefers moving water, individuals gather at quiet pools and springs in dry weather.

Management Implications: Extremely rare or absent throughout its former range in Arizona. Replaced by bullfrogs in parts of its range.

Important References: Stebbins, R.C. 1985. A field guide to western reptiles and amphibians. The Peterson Field Guide Series. Houghton Mifflin Company, New York, NY. 


\title{
Tehachapi Slender Salamander
}

\author{
Batrachoseps stebbinsi \\ Family Plethodontidae
}

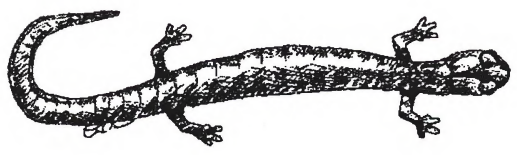

Global Rank: G2

State Rank: S2 (CA)

Distribution: Found in scattered localities in Tulare and Kern Counties, California, including the Caliente Creek drainage, Piute Mountains, at the southern end of the Sierra Nevada, and through the Tehachapi Mountains to Fort Tejon. Ranges from about 2,000 ft. (610 m.) to $4,600 \mathrm{ft}$. $(1,400 \mathrm{~m}$.) in elevation.

Description: Adults reach about $21 / 2$ in. (6 $\mathrm{cm}$ ) in snout-vent length. A broad-headed, long-limbed slender salamander with broad toes and feet. The toes seem to be more fully webbed than in other slender salamanders, with only one segment of each toe free of the web. There are 18-19 costal grooves and 6-7 costal folds between the toes of adpressed limbs. Coloration above is light to dark brown, reddish, or with light beige patches. The dorsal stripe, when present, is often diffused with uneven borders. There are few or no light specks along the central part of body.

Reproduction: Eggs laid in moist places

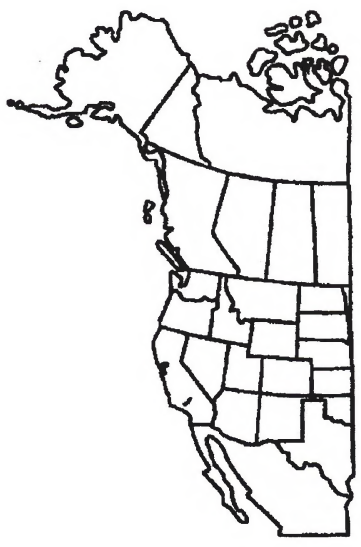

Current range of the under surface objects. Breeding season sus- 
pected to be from November to February, with peak activity in November and December. Clutch size is unknown.

Food: Eats small insects and other invertebrates which it searches for or waits for under surface objects.

Habits: Prefers moist canyons and ravines in all successional stages of blue oak savannah, digger pine-oak, and deciduous types. Other habitats are mountain meadows and all successional stages of mixed conifers. Found under rocks often in or near talus slopes and beneath rotting logs, especially in areas where there is considerable leaf litter.

Management Implications: First described in 1968. Rare in California where it is found only in Tulare and Kern Counties.

Important References: Stebbins, R.C. 1985. A field guide to western reptiles and amphibians. The Peterson Field Guide Series. Houghton Mifflin Company, New York, NY; Verner, J., and A.S. Boss. 1980. California wildlife and their habitats: western Sierra Nevada. USDA Pacific Southwest Forest and Range Experiment Station, GTR PSW-37, Berkeley, CA. 


\section{Texas Toad}

\section{Bufo speciosus}

Family Bufonidae

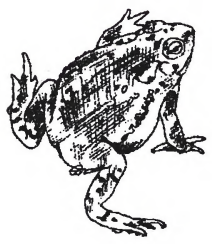

Global Rank: G5

State Rank: S3 (NM)

Distribution: In New Mexico, this toad occurs only in the southeast in Lea, Chaves, and Eddy Counties. Overall, it ranges from extreme southwestern Kansas to Texas, into northeastern Mexico. It ranges from near sea level to about $4,000 \mathrm{ft}$. $(1,220 \mathrm{~m}$.) in elevation.

Description: Adults range to $31 / 2$ in. (8.7 $\mathrm{cm}$.) in snout-vent length. The Texas toad is a rather plain-colored, uniformly warty species with no dorsal stripe. Cranial crests are weak or absent. Tubercles on hind foot usually blackish and sharp-edged, the inner one sickleshaped. Parotoid glands are oval and widely spaced. Coloration above is greenish gray to brown, sometimes with dark blotches on the back that are arranged in symmetrical pairs, and white to cream below, unmarked or with dark spots. Young have gray-brown coloration above, blotched with green and flecked with black, and warts tipped with red. Adult males have olive-colored skin on the deflated, sausage-shaped vocal sac which is covered by pale skin folds. The voice is a continuous

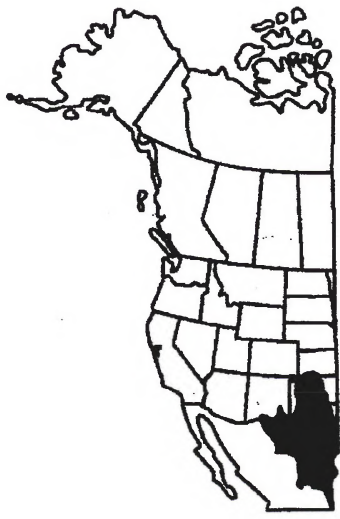

Current range of the Texas toad series of explosive, shrill trills. 
Reproduction: Breeds after summer rainfall in almost any standing water, and may appear in deep muddy cattle tanks as well as roadside ditches or flooded low-lying grassy areas. After rainfall, the males reach the breeding areas first and begin calling. Fertilized eggs are laid in long strings and hatch in about two days. Tadpoles and newly transformed young have been found in July and August.

Food: Diet is largely unknown, although they probably feed on a variety of terrestrial and flying arthropods.

Habits: Shows a preference for sandy soils, generally in short-grass plains or mesquite savannahs.

Management Implications: Restricted range in New Mexico. It is abundant in mesquite grassland areas along the Black River in southern Eddy County. Hybridizes with similar toads.

Important References: Stebbins, R.C. 1985. A field guide to western reptiles and amphibians. The Peterson Field Guide Series. Houghton Mifflin Company, New York, NY; Degenhardt, W.G., C.W. Painter, and A.H. Price. 1996. Amphibians and reptiles of New Mexico. University of New Mexico Press, Albuquerque, NM. 


\title{
Tiger Salamander
}

\author{
Ambystoma trigrinum
}

Family Ambystomatidae

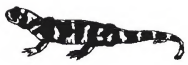

Barred

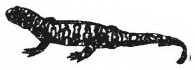

Arizona

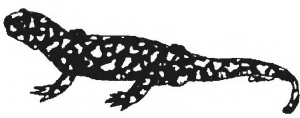

Blotched

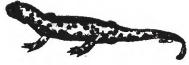

Gray

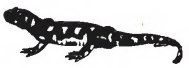

California

Global Rank: G5

State Rank: S3 (WA); S3S4 (WY);

S5 (AZ, CO, ID, MT, NM, UT);

SE (NV); SU (OR); S? (CA)

Distribution: Found throughout parts of North America from southern Canada to Mexico. In the West, they are absent from most of the Great Basin, most of Pacific Coast, Mohave and Colorado Deserts. They have been introduced in many locations west of the Rocky Mountains. Tiger salamanders have been found from near sea level to around $12,000 \mathrm{ft}$. (3,660 m.) in the Rocky Mountains.

Description: There are at least five subspecies of tiger salamanders in the West, differing mainly by color patterns (shown in drawings), and classification has been further confused through introductions using different population sources. Adults reach up to 12 in. (30

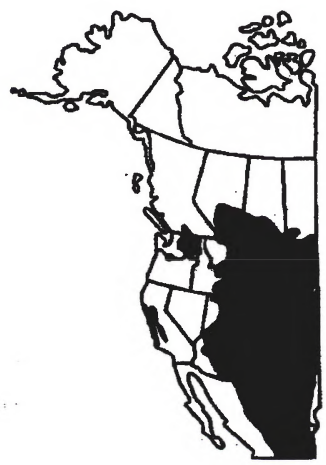
$\mathrm{cm}$.) in total length. Key characteristics include a variable body color pattern, but the background color is usually dark green to black, with blotches of yellow, tan, or green. The body is large and cylindrical with about 13
Current range of the tiger salamanders 
costal grooves on each side. The tail is about half the length of the body, and the skin is moist and scaleless. Larvae may exceed 9 in. $(22 \mathrm{~cm}$.) in total length, and are identified by long, feathery external gills; 14 to 24 gill rakers; and uniform dorsal coloration.

Reproduction: During breeding activities in the spring, the salamanders swarm in the ponds. Being without external gills, they can be seen coming to the water surface to breathe. During courtship, the males deposit a spermophore, or small tent-shaped structure containing sperm, on the bottom of the habitat or attached to bottom debris. Females pick up a spermatophore in the lips of her cloaca and fertilize eggs either before or as they are laid. Tiger salamanders lay up to 1,000 eggs, singly or in small clusters, on submerged vegetation. Clusters are usually linearly arranged and attached to objects. Larvae metamorphose in the first or second summer.

Food: Adult tiger salamanders eat any small animal that can be captured and swallowed. Larvae eat aquatic invertebrates and small vertebrates (especially amphibian larvae) as available. Larger larvae may become cannibals.

Habits: Found in virtually any habitat, providing there is a nearby body of water suitable for breeding. Activity is often associated with rainfall, especially from mid-March through September, and tiger salamanders become inactive in winter in colder climates. Terrestrial adults are usually underground in self-made burrows, or in those made by rodents or other animals. They are most conspicuous when adults move to the breeding areas in April and May and again in September when larvae transform and leave the water to find suitable winter homes. In some years, drying of breeding ponds may result in total reproductive failure.
Management Implications: Extensive use of tiger salamander larvae as fish bait and expanded irrigation in arid lands has resulted in introductions of this species outside its natural range and in the mixing of natural populations, especially in the Southwestern United States.

Important References: Stebbins, R.C. 1985. A field guide to western reptiles and amphibians. The Peterson Field Guide Series, Houghton Mifflin Company, New York, NY; Baxter, G.T., and M.D. Stone. 1980. Amphibians and reptiles of Wyoming. Wyoming Game and Fish Department, Cheyenne, WY; Groves, C.R., B. Butterfield, A. Lippincott, B. Csuti, and J.M. Scott. 1997. Atlas of Idaho's wildlife. Idaho Department of Fish and Game, Boise, ID. 


\section{Van Dyke's Salamander}

Plethodon vandykei

Family Plethodontidae

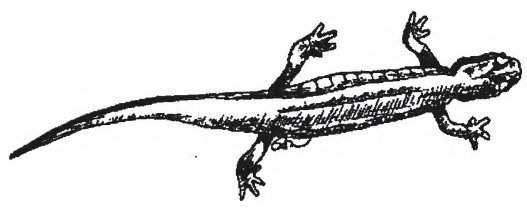

Global Rank: G3

State Rank: S2 (WA)

Distribution: Restricted to western Washington. Ranges from near sea level to around $5,000 \mathrm{ft}$. $(1,550 \mathrm{~m}$.) in elevation. Formerly was combined with the Coeur d'Alene salamander of Idaho and northwestern Montana.

Description: Adults reach to around $21 / 2$ in. $(6.2 \mathrm{~cm}$.) in snout-vent length and up to 4 in. $(10 \mathrm{~cm}$.) in total length. There are hairline furrows extending from each nostril to the edge of the upper lip and thin, moist skin. Dorsal stripes are yellowish, greenish, tan, or reddish, with even or scalloped edges, bordered with black or dark brown. The throat is pale yellow contrasting with a dark belly color, which is black or dusky flecked with white. Large adults are occasionally nearly plain dull yellow, tan, or pinkish rose with dark color of sides and belly faint or absent. There are usually 14 costal grooves and up to 3 costal folds between the toes of adpressed limbs. Parotoid glands often evident in large adults. Young have a conspicuous yellow dorsal stripe, black

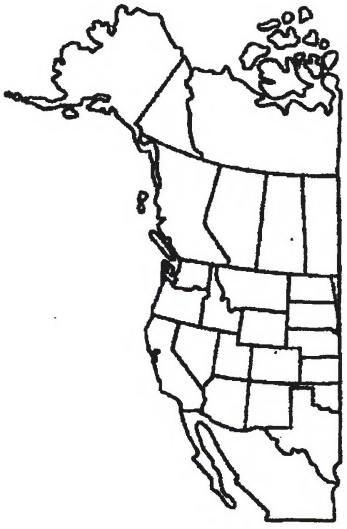

Current range of the Van Dyke's salamander sides, black belly, and a large yellow throat 
patch. Adult males have tubercles on the upper lip at the end of the nasolabial groove.

Reproduction: Breeding occurs in late summer and fall, and occasionally in the spring. Females can store sperm for long periods before fertilizing eggs, usually in the spring. Eggs are laid in moist concealed places in April through May, and young emerge in September.

Food: Feeds primarily on insects and other invertebrates, generally restricting foraging activities to moist spray areas, seeps, or streamside rocks and vegetation.

Habits: Found under rocks, logs, and bark near lakes, rivers, and streams, often in seepages where the soil is thoroughly wet. Occurs in both wooded and open areas from the lowlands well up into the mountains.

Management Implications: No known management concerns, except for restricted. range and importance of seepages and spray areas.

Important References: Stebbins, R.C. 1985. A field guide to western reptiles and amphibians. The Peterson Field Guide Series. Houghton Mifflin Company, New York, NY. 


\section{Western Redback Salamander}

\section{Plethodon vehiculum}

Family Plethodontidae

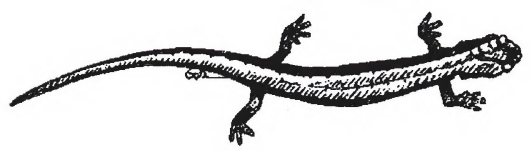

Global Rank: G5

State Rank: S5 (OR, WA)

Distribution: Ranges from Vancouver Island and coastal southern British Columbia south in the Coastal and Cascade Mountains to Curry County in southern Oregon. From near sea level to around 4,100 ft. $(1,250 \mathrm{~m}$.) in elevation.

Description: Adults reach to $21 / 2$ in. (6.2 $\mathrm{cm}$.) in snout-vent length, and about 4 in. (10 $\mathrm{cm}$.) in total length. Dorsal stripe is usually well defined in tan, reddish brown, orange, yellow, or dusky edged with black. The stripe has even edges, extending to the tip of the tail. Sides of body are dusky, sprinkled with white. Bottoms are blue-gray with varying amounts of yellowish or orange flecking. There usually are 16 costal grooves (range 14 to 18 ), and $21 / 2$ to $51 / 2$ costal folds between toes of adpressed limbs.

Reproduction: Breeds from November to March, laying a clutch of 10 (range 6-19) eggs, which the female broods until they hatch

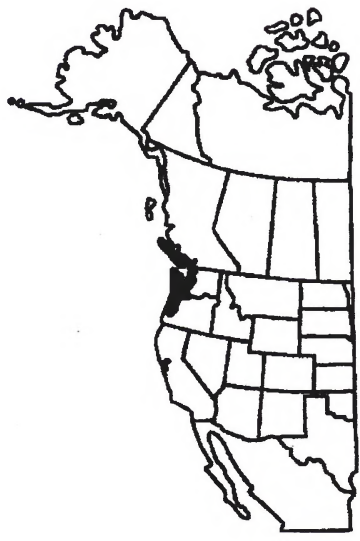

Current range of the western redback salamander in the fall. Females probably breed every other year. 
Food: Feeds on terrestrial invertebrates such as mites, springtails, beetles, sowbugs, ants, and spiders.

Habits: A forest dweller, this salamander occurs under logs, rocks, and debris throughout humid coniferous and deciduous forests. It is found in moist microhabitats, but is not closely associated with running water. Found under rocks, logs, bark, and boards in damp locations. The species is scarce to absent above the snowline. It is inactive in both cold and hot weather. Temperatures must be above freezing for courtship to occur. Juveniles remain in the nest until fall rains begin.

Management Implications: The most widespread and abundant woodland salamander in the Pacific Northwest.

Important References: Stebbins, R.C. 1985. A field guide to western reptiles and amphibians. The Peterson Field Guide Series. Houghton Mifflin Company, New York, NY; Csuti, B., A.J. Kimerling, T.A. O'Neil, M.M. Shaughnessy, E.P. Gaines, and M.M.P. Huso. 1997. Atlas of Oregon wildlife. Oregon State University Press, Corvallis, $O R$. 


\section{Western Spadefoot}

\section{Scaphiopus hammondii}

Family Pelobatidae

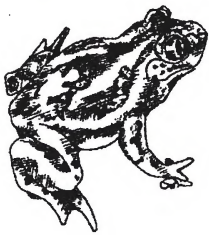

Global Rank: G3

State Rank: S3 (CA)

Distribution: In the Great Valley of California, bordering foothills, and Coast Ranges south of San Francisco Bay, into Baja California to Mesa de San Carlos. Elevations usually below $3,000 \mathrm{ft}$. $(910 \mathrm{~m}$.).

Description: Adults reach to $21 / 2$ in. (6.2 $\mathrm{cm}$.) in snout-vent length. There is no cranial boss between the eyes. Coloration above is dusky green or gray, often with four irregular, light-colored stripes on the back. The central pair sometimes set off a dark, hourglassshaped area. Skin tubercles are tipped with orange or reddish. The eye (iris) is usually pale gold. The body is whitish below, without markings. A wedge-shaped, glossy black spade is on each hind foot. The distance between the eyes is usually less than the width of the eyelid. The voice is hoarse, snore-like, and it may call from a floating position.

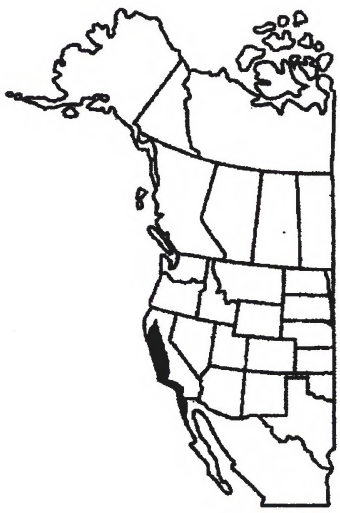

Reproduction: Eggs laid in vernal pools, ponds, and occasionally in slow streams from February to April, with peak activity in March. Mean clutch size is 400 (range 300 to 500). 
Food: Feeds on insects and other invertebrates, usually from the surface of ponds.

Habits: Primarily a species of the lowlands, frequenting washes, floodplains of rivers, alluvial fans, playas, and alkali flats. Also ranges into the foothills and mountains. Prefers areas of open vegetation and short grasses, where the soil is sandy or gravelly. Found in valley and foothill grasslands, open chaparral, and pine-oak woodlands.

Management Implications: Now extinct throughout much of lowland southern California. Most habitat loss due to agricultural conversion. When handled, this toad may smell like roasted peanuts and its skin secretion may cause sneezing.

Important References: Stebbins, R.C. 1985. A field guide to western reptiles and amphibians. The Peterson Field Guide Series. Houghton Mifflin Company, New York, NY; Verner, J., and A.S. Boss. 1980. California wildlife and their habitats: western Sierra Nevada. USDA Pacific Southwest Forest and Range Experiment Station, GTR PSW-37, Berkeley, CA. 


\section{Western Toad}

\section{Bufo boreas \\ Family Bufonidea}

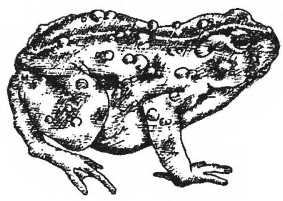

FWS Status: Candidate (Boreal Toad subspecies)

BLM Status: Sensitive (ID)

Global Rank: G4

State Rank: S1 (CO, WY); S2 (UT); S3 (AK); S4 (ID, NV, OR); S5 (CA); S3S4 (MT, WA); SH (NM)

Distribution: Found along the Pacific Coast from southern Alaska to Baja California, and extending to west-central Alberta, western Montana, most of Idaho and Nevada, central Utah and Colorado, and parts of Wyoming and New Mexico. Absent from most of arid southwest US and southcentral Washington. They occur from sea level to over $11,800 \mathrm{ft}$. $(3,600$ $\mathrm{m}$.) in a wide variety of habitats, including desert springs and streams, meadows and woodlands, and in and around ponds, lakes, reservoirs, and slow-moving rivers and streams. Two subspecies are known: the boreal toad ( $B . b$. boreas) throughout most of its range, and the California toad ( $B$. b. halophilus) in most parts of California.

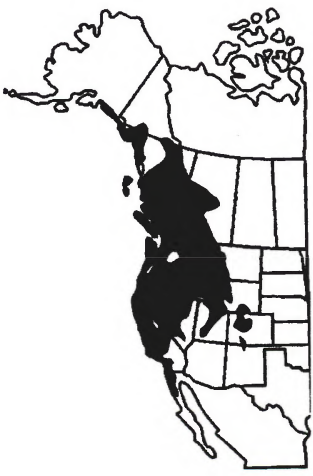

Description: Adult western toads measure up to 5 in. $(12.5 \mathrm{~cm}$.) in snout-vent length. Key Current range of the western toad characteristics include a light vertebral stripe; 
no cranial crests; parotoid glands are oval, well separated, and slightly larger than the upper eyelids; horizontal pupils; dry, warty skin; two tubercles on each hind foot. Dorsal coloration may be brown, gray, or green, and individuals can lighten or darken color to match background. Females reach larger sizes than males. Recently transformed young may have absent or weak dorsal stripe, prominent spotting, and yellow undersides of feet. The western toad has no vocal sac for a loud mating call; their voice is a mellow chirruping.

Reproduction: Breeding usually occurs from late January through July, depending on latitude, elevation, and local conditions. Eggs are laid in two, long, intertwined strands of gel, containing up to 16,000 eggs per clutch. Eggs may be laid on the bottom in slow moving water or wrapped around objects such as sedges and branches. Eggs hatch in 3 to 10 days, depending upon water temperature. Tadpoles may be up to 1 in. $(2.5 \mathrm{~cm}$.) in total length, are usually very dark with dark tail musculature, rounded bodies, and intestines usually not visible. The tadpoles are relatively slow swimmers and are often found in dense aggregations of hundreds to thousands of individuals. Larvae metamorphose in the second summer in high elevations and the first summer in other locations.

Food: Adults eat all types of flying insects, spiders, crayfish, sowbugs, and earthworms. Larvae filter suspended plant material or feed on algae and bottom detritus.

Habits: Digs burrow in loose soil or uses burrows of small mammals in or near wet areas. Active at night in warm, low-lying areas; diurnal at higher elevations. Hibernates in winter in cold climates. Tends to walk rather than hop. Adults preyed upon by birds and garter snakes; young fed on by larvae of predatory insects. High mortality may occur between egg stage and adulthood. Populations appear to be declining in the Greater Yellowstone Ecosystem and in some other parts of their range.

Management Implication: Threats to western toads include loss and fragmentation of habitat and competition/direct impacts from exotic species of plants and animals. While western toads have adapted well to irrigation canals, they are adversely impacted by vegetation removal, changes in water quality, and trampling by livestock; drought and water diversions; and human expansion and developments. The impacts to western toads of increased ultraviolet radiation, parasites, or other factors which may be causing worldwide declines in amphibians are still unknown.

Important References: Stebbins, R.C. 1985. A field guide to western reptiles and amphibians. The Peterson Field Guide Series, Houghton Mifflin Company, New York, NY; Csuti, B., A.J. Kimerling, T.A. ONeil, M.M. Shaughnessy, E.P. Gaines, and M.M.P. Huso. 1997. Atlas of Oregon wildlife. Oregon State University Press, Corvallis, OR; Groves, C.R., B. Butterfield, A. Lippincott, B. Csuti, and J.M. Scott. 1997. Atlas of Idaho's wildlife. Idaho Department of Fish and Game, Boise, ID. 


\section{Wood Frog}

\section{Rana sylvatica \\ Family Ranidae}

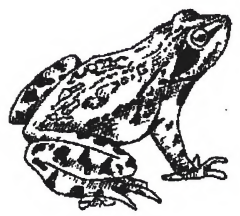

BLM Status: Sensitive (MT)

Global Rank: G5

State Staus: S2 (WY); S3 (CO); S3S4 (AK); SH (ID); SR (MT)

Distribution: Found in most of Alaska and Canada, southward in eastern United States to the southern Appalachian Mountains. Also found in extreme northern Idaho and northwestern Montana. Disjunct populations found in Arkansas and Missouri, and, in the west, at several locations in Wyoming and northcentral Colorado. The distribution of the wood frog follows closely the distribution of spruce.

Description: Adult wood frogs reach up to 2 in. $(5 \mathrm{~cm}$.) in snout-vent length. Key characteristics include a pointed snout; a dark mask with a light lip line; brown, gray, or bluegreenish coloration on dorsal surface; may have spots; and the webbing does not extend to the tip of the toes. Skin is smooth with

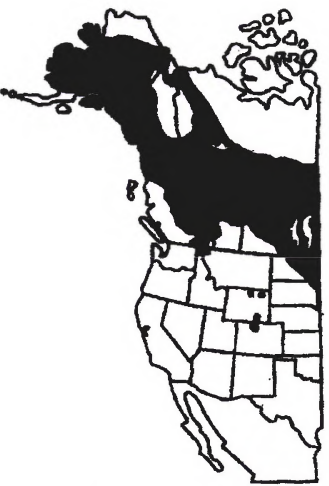

distinct dorsolateral folds. Some populations have mid-dorsal light stripe. Ventral coloration is white and mottled. Hind legs are shorter than most true frogs. Tadpoles reach up to 2 in. $(5 \mathrm{~cm}$.) with key characteristics of dark olive or brownish dorsal coloration; a cream
Current range of the wood frog 
colored ventral coloration with pinkish iridescence; a short snout; large dorsally located eyes; and the tail almost twice as long as the body. Adult males develop swollen and darkened thumb base and paired vocal sacs, one over each forelimb. The voice is a series of rather high grating notes lasting one second or less, similar to the clucking of domestic ducks.

Reproduction: Wood frogs breed shortly after ice has melted from ponds and small lakes. Females lay eggs as late as July, depending upon elevations. Up to 3,000 eggs are laid in baseball-sized clutches, and many females may deposit their eggs at the same site. Larvae metamorphose in the spring or summer. Adults become sexually mature in two to three years.

Food: Diet of the wood frog includes a variety of small invertebrates, especially terrestrial insects. Larval forms eat algae, plant tissue, organic debris, and minute water-borne organisms.

Habits: Inactive during cold seasons in north and at high elevations. Hides in humus, leaf litter, under rocks, or in/under logs. Most active in summer in damp conditions during the daytime, but breeding activity may occur at night. After leaving ponds at the end of breeding activity or metamorphosing from larvae, adults usually remain in an area less than 100 $\mathrm{m}$. across. Wood frog skin secretions repulse predators such as shrews and aquatic insects.

Management Implications: This is the only amphibian in North America to occur north of the Arctic Circle. The relic population in the Medicine Bow Mountains of Wyoming extending south into Colorado appears to be healthy. However, the population status in Wyoming's Big Horn Mountains is unknown. Idaho's population is believed to be rare. Montana's population may be adversely im- pacted by habitat modification and human development.

Important References: Stebbins, R.C. 1985. A field guide to western reptiles and amphibians. The Peterson Field Guide Series, Houghton Mifflin Company, New York, NY; Baxter, G.T., and M.D. Stone. 1980. Amphibians and reptiles of Wyoming. Wyoming Game and Fish Department, Cheyenne, WY; Groves, C.R., B. Butterfield, A. Lippincott, B. Csuti, and J.M. Scott. 1997. Atlas of Idaho's wildlife. Idaho Department of Fish and Game, Boise, ID. 


\section{Woodhouse's Toad}

\section{Bufo woodhousei \\ Family Bufonidae}

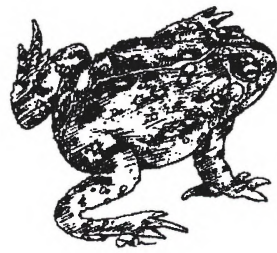

Global Rank: G5

State Rank: S2 (OR); S3 (ID, WA);

S4 (CA, MT, WY); S5 (AZ, CO, NV, UT, NM)

Distribution: Woodhouse's toad ranges from Montana to Mexico and from Iowa to Nevada, but is absent from higher elevations of the Rocky Mountains and the West Coast. It may be found from near sea level to as high as $8,500 \mathrm{ft}$. $(2,590 \mathrm{~m}$.) in elevation.

Description: Adults reach up to 5 in. (12.5 $\mathrm{cm}$.) in snout-vent length. Key characteristics include cranial crests or boss with L-shaped ridges of bone between and behind the eyes; elongated parotoid glands behind the eyes; light vertebral stripe; horizontal pupils; dry, warty skin; and two horny tubercles on underside of hindfeet. Coloration varies from gray, yellowish brown, olive, or blackish above, usually with dark blotches. There often is a

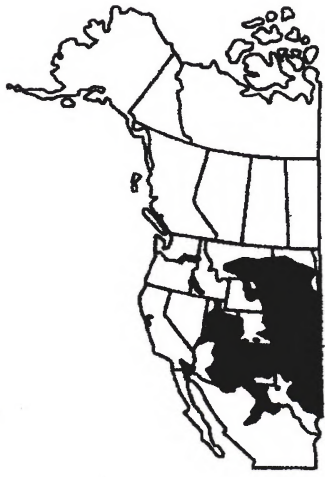
yellow and black network on the rear of the thighs, and cream to beige coloration on lower surface, possibly with dark flecks. Tadpoles reach up to 1 in. $(2.5 \mathrm{~cm}$.) in total length, with
Current range of the Woodhouse's toad 
key characteristics including dark brown to black mottling coloration on body; tail musculature dark above and light below; and a round body with a jutting snout. Adult males have a sooty throat, set off by a pale yellow border on the lower jaw. The voice has been compared to a snore, infant's cry, and bawling of a calf. It is a nasal $w-a-a-a-a h$, starting as an explosive wheezy sound dropping in pitch at the end. The vocal sac is round.

Reproduction: Breeding usually begins after spring rains with choruses lasting a few weeks. Females lay up to 25,000 eggs in the spring or early summer. Eggs are in two, long, intertwined strands, each composed of a single gel layer. Strands may be wrapped around submerged vegetation or branches. Tadpoles metamorphose in one to two months, and become sexually mature in two years.

Food: Adults feed on a variety of invertebrates, especially ants, beetles, and other small, terrestrial arthropods. Larvae eat a variety of algae, plant tissues, and organic debris.

Habits: Found in grasslands, shrub steppe, woods, river valleys, floodplains, and agricultural land, usually in areas with deep soils. Does well in areas of only temporary water habitats. The toads are mostly nocturnal, but diurnal activity is not uncommon. They are active in both wet and dry weather, but may become inactive during cold weather in the fall, winter, and spring. When inactive, they burrow underground or hide under rocks, plants, or other cover.

Management Implications: Woodhouse's toads are relatively common throughout their range. However their future health depends upon permanent water being maintained within their range.
Important References: Stebbins, R.C. 1985. A field guide to western reptiles and amphibians. The Peterson Field Guide Series, Houghton Mifflin Company, New York, NY; Groves, C.R., B. Butterfield, A. Lippincott, B. Csuti, and J.M. Scott. 1997. Atlas of Idaho's wildlife. Idaho Department of Fish and Game, Boise, ID; Baxter, G.T., and M.D. Stone. 1980. Amphibians and reptiles of Wyoming. Wyoming Game and Fish Department, Cheyenne, WY. 


\section{Yosemite Toad}

\section{Bufo canorus}

Family Bufonidae

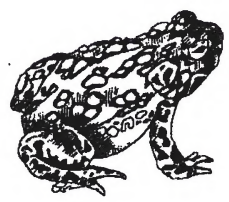

Global Rank: G1G2

State Rank: S1S2 (CA)

Distribution: Restricted to the high Sierra Nevada of California from the vicinity of Grass Lake, Eldorado County, to south of Kaiser Pass and Evolution Lake, Fresno County. Ranges from about $4,800 \mathrm{ft}$. $(1,460 \mathrm{~m}$.) to $12,000 \mathrm{ft} .(3,630 \mathrm{~m}$. $)$ in elevation.

Description: Adults reach about 23/4 in. (6.9 $\mathrm{cm}$.) in snout-vent length. Differs from close relatives by having smoother skin, large, flat paratoids less than the width of a gland apart, and closely set eyes. The distance between the eyes is less than the width of the upper eyelid. Sexes vary greatly in color. Females and young have many blotches on a pale background, paratoids are usually tan-colored, and the dorsal stripe is usually narrow or absent. Males have pale yellow-green or dark olive coloration above, with dark blotches virtually absent or reduced to small scattered flecks. Throats of males and females are similar.

Reproduction: Breeds in shallow pools and lake margins, or in the quiet water of streams

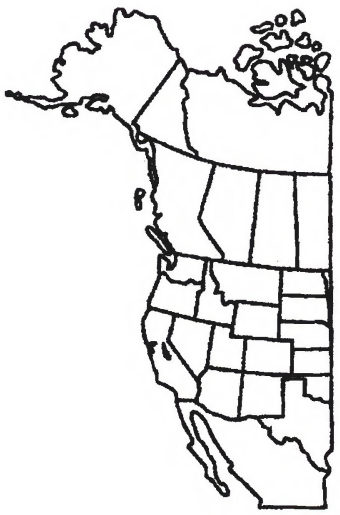
during April through July. Eggs are laid April to June, with a peak activity in late May. Wa- 
ter temperature may be a factor in determining when egg laying takes place. Mean egg clutch size is 8,000 (range 6,000 to 15,000 ).

Food: Preys on insects and other invertebrates, foraging on the surface of the ground.

Habits: Prefers mountain meadows, lodgepole pine, and alpine meadow types. Also found in all successional stages of mixed-conifer, Jeffrey pine, and red fir types. Emerge soon after snow melts. Active from April through October, but is chiefly diurnal and usually active only in sunlit areas. On cool days, may not be active until afternoon. The toad seeks shelter in burrows of gophers and meadow mice and in clumps of grass, sedges, or willows near water.

Management Implications: Limited and fragile habitat. Territories restricted to vicinity of calling males. Suspected home ranges are about a half acre.

Important References: Stebbins, R.C. 1985. A field guide to western reptiles and amphibians. The Peterson Field Guide Series. Houghton Mifflin Company, New York, NY; Verner, J., and A.S. Boss. 1980. California wildlife and their habitats: western Sierra Nevada. USDA Pacific Southwest Forest and Range Experiment Station, GTR PSW-37, Berkeley, CA. 


\section{Status of Amphibians by States (Federal and BLM):*}

Common Name

Alaska:

Alaska worm salamander

Spotted frog

\section{Arizona:}

Sonoran tiger salamander Chiricahua leopard frog

\section{Califomia:}

Desert slender salamander Arroyo toad

California red-legged frog California tiger salamander Inyo Mountains slender salamander Tehachapi slender salamander Yellow-blotched salamander Foothills yellow-legged frog San Sebastian leopard frog Couch's spadefoot toad

\section{Colorado:}

None

\section{Idaho:}

Spotted frog

Coeur d'Alene salamander

Northern leopard frog

Western toad

\section{Montana:}

Coeur d'Alene salamander

Canadian toad

Spotted frog

Wood frog

Tailed frog
Scientific Name

$\underline{\text { Status }}$

Batrachoseps caudatus

BLM-S

Rana pretiosa

BLM-S

Ambystoma tigrinum stebbinsi

F-E

Rana chiricahuensis
Batrachoseps aridus

Bufo microscaphus californicus

Rana aurora draytonii

Ambystoma tigrinum californiense

Batrachoseps campi

Batrachoseps stebbinsi

Ensatina eschscholtzi croceator

Rana boylei

Rana yavapaiensis

Scaphiopus couchi
F-E

F-E

F-T

F-C

BLM-S

BLM-S

BLM-S

BLM-S

BLM-S

BLM-S
F-C; BLM-S

BLM-S

BLM-S

BLM-S
Rana pipiens
Bufo boreas

Rana luteiventris
Plethodon vandykei idahoensis
BLM-S

BLM-S

BLM-S

BLM-S

BLM-S 
Nevada:

Columbia spotted frog

Arizona toad

Amargosa toad

New Mexico:

Chiricahua leopard frog

\section{Oregon:}

Columbia spotted frog

Oregon spotted frog

Northern leopard frog

Columbia torrent salamander

Utah:

Spotted frog

Arizona toad

Boreal toad

Lowland leopard frog

Pacific chorus frog

\section{Washington:}

Columbia spotted frog

Oregon spotted frog

Larch Mountain salamander

\section{Wyoming:}

Wyoming toad
Rana luteiventris (Great Basin pop.)

F-C

Bufo microscaphus microscaphus

BLM-S

Bufo nelsoni

Rana chiricahuensis

F-PT

Rana luteiventris

F-C

Rana pretiosa

F-C

Rana pipiens

BLM-S

Rhyacotriton kezeri

BLM-S

Rana luteiventris $\quad$ F-C

Bufo microscaphus BLM-S

Bufo boreas boreas BLM-S

Rana yavapaiensis BLM-S

Pseudacris regilla BLM-S

Rana luteiventris $\quad$ F-C

Rana pretiosa F-C

Plethodon larselli BLM-S

Bufo hemiophrys bateri F-E

${ }^{*}$ Based upon information available from www.natureserve.org and provided by BLM state coordinators. 


\section{Important Sources of Amphibian Information:}

Baxter, G.T., and M.D. Stone. 1980. Amphibians and reptiles of Wyoming. Wyoming Game and Fish Department, Cheyenne, WY. 136 pp.

Beck, J.M., J. Janovetz, and C.R. Peterson. 1998. Amphibians of the Coeur d'Alene basin: a survey of Bureau of Land Management Lands. Idaho Bureau of Land Management, Boise, ID. Technical Bulletin No. 98-3. 100 pp.

Behler, J.L., and F.W. King. 2000. The National Audubon Society field guide to reptiles and amphibians. Alfred A. Knopf, Publisher, New York, NY. 743 pp.

Bernard, S.R., and K.F. Brown. 1977. Distribution of mammals, reptiles, and amph ibians by BLM physiographic regions and A.W. Küchler's associations for the eleven western states. USDI, Bureau of Land Management, Denver, CO. Technical Note 301. 169 pp.

Blaustein, A.R., J.J. Beatty, D.H. Olson, and R.M. Storm. 1995. The biology of amphibians and reptiles in old-growth forests in the Pacific Northwest. Gen. Tech. Rep. PNW-GTR-337. USDA, Forest Service, Pacific Northwest Research Station, Portland, OR. 98 pp.

Brown, V. 1974. Reptiles and amphibians of the West. Naturegraph Publishers, Happy Camp, CA. $79 \mathrm{pp}$.

Cassirer, F., C. Johnson, D. David, and C. Peterson. 1994. The Coeur d'Alene salamander (Plethodon idahoensis) in Idaho. Idaho State Conservation Effort, Idaho Department of Fish and Game, Boise, ID. 22 pp.

Cockran, C.C., and C.R. Thomas. 1996. Amphibians of Oregon, Washington, and British Columbia - A field identification guide. Lone Pine Publishing, Vancouver, BC. 180 pp.

Conant, R., R.C. Stebbins, and J.T. Collins. 1992. Peterson field guide to reptiles and amphibians. Houghton Mifflin Company, New York, NY. 128 pp.

Christensen B. 1999. Monitoring report of the Columbia spotted frog (Rana luteiventris), 1999: Great Basin population, Nevada Toiyabe Range. Humbolt-Toiyabe National Forest, Austin Ranger District, Austin, NV. 9 pp.

.2000. Visual encounter survey and habitat assessment of the Columbia spotted frog (Rana luteiventris), 1999: Great Basin population, Nevada Toiyabe Range. Humbolt-Toiyabe National Forest, Austin Ranger District, Austin, NV. 14 pp.

Csuti, B., A.J. Kimerling, T.A. O’Neil, M.M. Shaughnessy, E.P. Gaines, and M.M.P. Huso. 1997. Atlas of Oregon Wildlife. Oregon State University Press, Corvallis, OR. 492 pp. 
Degenhardt, W.G., C.W. Painter, and A.H. Price. 1996. Amphibians and reptiles of New Mexico. University of New Mexico Press, Albuquerque, NM. 431 pp.

Drost, C.A., and G.M. Fellers. 1996. Collapse of a regional frog fauna in the Yosemite area of the Sierra Nevada. Conservation Biology. 10(2):414-425.

Duellman, W.E. (Ed). 1999. Patterns of distribution of amphibians: a global prespective. Johns Hopkins Univeresity Press, Baltimore, MD. 648 pp.

, and L. Trueb. 1994. Biology of amphibians. Johns Hopkins University Press, Baltimore, MD. 670 pp.

Dvomich, K.M., K.R. McAllister, and K. B. Aubry. 1997. Amphibians and reptiles of Washington State: Location data and predicted distributions, Volume 2 In Washington State Gap Analysis - Final Report, (K.M. Cassidy, C.E. Grue, M.R. Smith and K.M. Dvornich, eds.). Washingt on Cooperative Fish and Wildlife Research Unit, University of Washington, Seattle, WA. $146 \mathrm{pp}$.

Engle, J.C., and J.C. Munger. 1998. Population structure of spotted frogs in the Owyhee Mountains. Idaho Bureau of Land Management, Boise, ID. Technical Bulletin No. 98-20. $10 \mathrm{pp}$.

Fellers, G.M. 1997. Design of amphibian surveys. Pages 23-34 In D.H. Olson, W.P. Leonard, and R.B. Bury (eds.). Sampling Amphibians in Lentic Habitats: Methods and Approaches for the Pacific Northwest. Northwest Fauna 4.

, and C.A. Drost. 1994. Sampling with artifical cover. Pages 146-150 In W.R. Heyer, M.A. Donnelly, R.W. McDiarmid, L.C. Hayek, and M.S. Foster (eds.). Measuring and Monitoring Biological Diversity: Standard Methods for Amphibians. Smithsonian Institution Press. 364 pp.

, and K.L. Freel. 1995. A standardized protocol for surveying aquatic amphibians. National Biological Service, Cooperative Park Study Unit, University of California, Davis, CA. Technical Report NPS/WRUC/NRTR-95-01. 123 pp.

Gerber, M.F., J.C. Munger, A. Ames, and J. Stewart. 1997. Reptiles and amphibians in deep canyons: the Big Jacks and Little Jacks creek drainages of Owyhee County, Idaho. Idaho Bureau of Land Management, Boise, ID. Technical Bulletin No. 97-1.21 pp.

Gomez, D. 1994. Conservation assessment for the spotted frog (Rana pretiosa) in the intermountain region. USDA, Forest Service, Intermountain Region, Ogden, UT. 30 pp.

Groves, C.R., B. Butterfield, A. Lippincott, B. Csuti, J.M. Scott. 1997. Atlas of Idaho's wildlife. Idaho Department of Fish and Game, Nongame and Endangered Wildlife Program. Boise, ID. $372 \mathrm{pp}$. 
Hammerson, G.A. 1999. Amphibians and reptiles in Colorado. University Press of Colorado, Niwot, Colorado. 484 pp.

Heyer, W.R., R.W. McDiarmid, M. Donnelly, and L. Hayek (eds.). 1994. Measuring and monitoring biological diversity - Standard methods for amphibians. Smithsonian Institution Press, Washington, D.C.

Idaho Wildlife.1989. Idaho's amphibians \& reptiles. Description, habitat \& ecology. Nongame Wildlife Leaflet \#7. Diane Ronayne (ed.). Idaho Fish and Game Department. Boise, ID. 11 pp.

Jones, K.B. 1981. Distribution, ecology, and habitat management of the reptiles and amphibians of the Hualapai-Aquarius planning area, Mohave and Yavapai Counties, Arizona. USDI, Bureau of Land Manage ment, Phoenix District, Phoenix, AZ. Technical Note $353.134 \mathrm{pp}$.

Klott, J. 1996. Sensitive animals of the Jarbidge Resource Area, Idaho. Idaho Bureau of Land Management, Boise, ID. Technical Bulletin No. 96-10. 46 pp.

Koch, E.D., and C.R. Peterson. 1996. Amphibians and reptiles of Yellowstone and Grand Teton National Parks. University of Utah Press, Salt Lake City, UT. 188 pp.

, G. Wood, C.R. Peterson, and P.S. Corn (eds.). 1997. A summary of the conference on declining and sensitive amphibians in the Rocky Mountains and Pacific Northwest. Idaho Herpetological Society and U.S. Fish and Wildlife Service, Snake River Basin Office Report, Boise, ID. 96 pp.

Leonard, W.P., H.A. Brown, L.C. Jones, K.R. McAllister, and R.M. Storm. 1993. Amphibians of Washington and Oregon. Seattle Audubon Society, Seattle, WA. 168 pp.

, and K.R. McAllister. 1996. Past distribution and current stat us of the northern leopard frog (Rana pipiens) in Washington. Washington Department of Fish and Wildlife, Olympia, WA. 17 pp.

Llewellyn, R.L., and C.R. Peterson. 1998. Distribution, relative abundance, and habitat associations of amphibians and reptiles on Craig Mountain, Idaho. Idaho Bureau of Land Management, Boise, ID. Technical Bulletin No. 98-15. 165 pp.

Makela, P.D. 1998. A survey for northern leopard frogs (Rana pipiens) in the Snake River Resource Area: 1997. Idaho Bureau of Land Management, Bo ise, ID. Technical Bulletin No. $98-8.58$ pp.

Mattoon, A. July/August 2000. Amphibia fading. Pages 12-23 In World Watch. E. Ayers (ed.). Vol. 13, No. 4. The Worldwatch Institute, Washington, D.C. 
2001. Deciphering amphibian declines. Pages 63-82 In State of the World, 2001. The Worldwatch Institute, Washington, D.C. 275 pp.

McDonald, M., and R.F. Marsh 1995. Amphibian inventory of the Jarbidge Resource Area, Boise District. Idaho Bureau of Land Management, Boise, ID. Technical Bulletin No. 954. $23 \mathrm{pp}$.

1996. Amphibian inventory of the Jarbidge and Snake River Resource Areas. Idaho Bureau of Land Management, Boise, ID. Technical Bulletin No. 96-13. 23 pp.

Morell, V. 2001. The fragile world of frogs. Pages 106-123 In National Geographic, 199 (5).

Munger, J.C., L. Heberger, D. Logan, W. Peters on, L. Mealy, and M. Cauglin. 1994. A survey of the herpetofauna of Bruneau Resource Area, Boise District, with focus on the spotted frog, Rana pretiosa. Idaho Bureau of Land Management, Boise, ID. Technical Bulletin No. 94-7. 61 pp.

, C.R. Peterson, M. McDonald, and T. Carrigan. 1995. Spotted frog (Rana pretiosa). Idaho State Conservation Effort, Idaho Department of Fish and Game, Boise, ID. 33 pp.

, M. Gerber, M.A. Carroll, K. Madrid, and C. Peterson. 1996. Status and habitat associations of the spotted frog Rana pretiosa in Southwestem Idaho. Idaho Bureau of Land Management, Boise, ID. Technical Bulletin No. 96-1. 110 pp.

, A. Ames, and B. Barnett. 1997. 1996 survey for Columbia spotted frogs in the Owyhee Mountains of Southwestern Idaho. Idaho Bureau of Land Management, Boise, ID. Technical Bulletin No. 97-13. 27 pp.

, M. Gerber, K. Madrid, M.A. Carroll W. Petersen, and L. Heberger. 1998. U.S. National Wetland Inventory classifications as predictors of the occurrence of Columbia spotted frogs (Rana luteiventris) and Pacific treefrogs (Hyla regilla). Pages 320-330 In Conservation Biology. Volume 12, No. 2.

Nevada Division of Wildlife. 2000a. Population monitoring of the Amargosa toad (Bufo nelsoni) and habitat evaluation in Oasis Valley, Nevada. Nevada Division of Wildife, Reno, NV (January). 29 pp.

2000b. Conservation agreement for the Amargosa toad (Bufo nelsoni). Nevada Division of Wildlife, Reno, NV. 37 pp.

Nussbaum, R.A., E.D. Bodie, and R.M. Storm. 1983. Amphibians and reptiles of the Pacific Northwest. University Press of Idaho, Moscow, ID. 332 p. 
Olson, D.H., W.P. Leonard, and R.B. Bury, eds. 1997. Sampling amphibians in lentic habitats: methods and approaches for the Pacific Northwest. Society for Northwestern Vertebrate Biology. Northwest Fauna, Number 4. Olympia, WA. 134 pp. , and . 1997. Amphibian inventory and monitoring: a standardized appro ach for the Pacific Northwest. Northwest Fauna 4:1-21. Olympia, WA.

Panik, H.R., and S. Barrett. 1994. Distribution of amphibians and reptiles along the Truckee River system. Pages 197-204 In Northwest Science. Vol 68, No. 3.

Peterson, C.R, and H.J. Fabian. 1997. Photographic identification cards for Idaho amphibians. Department of Biological Sciences \& Idaho Museum of Natural History, Idaho State University. Pocatello, ID. 34 sheets.

Petranka, J.W. 1998. Salamanders of the United States and Canada. Smithsonian Institution Press, Washington, D.C. 587 pp.

Pyrom, J. 1987. Frogs and toads; a complete introduction. T.F.H. Publications, Inc., Neptune City, NJ. 96 pp.

Ramotnik, C.A. 1997. Conservation assessment of the Sacramento Mountain salamander. Gen. Tech. Rep. RM-GTR-293. USDA, Forest Service, Rocky Mountain Forest and Range Experiment Station, Ft. Collins, CO. 19 pp.

Reaser, J.K. 2000. Amphibian declines: an issue overview. Federal Taskforce on Amphibian Declines and Deformities. Washington, D.C. 31 pp.

Reichel, J., and D. Flath. 1995. Identification of Montana's amphibians and reptiles. Montana Outdoors (May/June), Montana Department of Fish, Wildlife, and Parks, Helena, MT. $20 \mathrm{pp}$.

Scott, N.J., and R.A. Seigel. 1992. The management of amphibian and reptile populations: species priorities and methodological and theoretical constraints. Pages 343-368 In Wildlife 2001: Populations. D.R. McCullough and R.H. Barrett, (eds.). Elsevier Applied Science, London, England.

Shipman, M., and S. Anderson. 1997. General survey of the Great Basin population of Columbia spotted frogs (Rana luteiventris) in the Jarbidge, Mountain City, and Santa Rosa Ranger Districts of Northern Nevada. Humbolt-Toryabe National Forest, Elko, NV. 9 pp.

Stebbins, R.C. 1954. Amphibians and reptiles of western North America. McGraw Hill Field Guide Series. McGraw Hill Book Company, Inc. New York, NY. 528 pp.

1985. A field guide to western reptiles and amphibians. The Peterson Field Guide Series. Houghton Mifflin Company. New York, NY. 336 pp. 
, and N.W. Cohen. 1995. A natural history of amphibians. Princ eton University Press, Princeton, NJ. 316 pp.

Stein, J. 1999. Amargosa toad (Bufo nelsoni) population monitoring and habitat evaluation in Oasis Valley, Nevada. Nevada Division of Wildlife, Las Vegas, NV. 22 pp.

Szaro, R.C., K.E. Severson, and D.R. Patton (technical coordinators). 1988. Management of amphibians, reptiles, and small mammals in North America. Pro ceedings of the symposium. USDA, Forest Service, Rocky Mountain Forest and Range Experiment Station, Ft. Collins, CO. General Technical Report RM-166. 458 pp.

Thompson, P. 1999. Amphibian surveys in the northern region, 1998. Utah Division of Wildlife Resources, Ogden, UT. 13 pp.

, and B. Schmitz. 1998. Amphibian surveys in the northern region, 1997. Utah Division of Wildlife Resources, Ogden, UT. 68 pp.

USDA. 1978. Species list. Birds, mammals, fish reptiles, and amphibians for the Forest Service. USDA, Forest Service, Northern Region, Missoula, MT. R1-78-002. 82 pp.

Verner, J., and A.S. Boss. 1980. California wildlife and their habitats: western Sierra Nevada. USDA Pacific Southwest Forest and Range Experiment Station, Berkeley, CA. GTR PSW-37. 439 pp.

Vertucci, F., and P.S. Corn. 1996. Evaluation of episodic acidification and amphibian declines in the Rocky Mountains. Ecological Applications 6(2):449-457.

Wilson, Jr., S.G., E.M. Wilson, C.R. Groves, and R.L. Wallace. 1997. U.S. distribution of the Coeur d'Alene salamander (Plethodon idahoensis Slater and Slipp). Pages 359-362 In Great Basin Naturalist 57(4).

Yeo, J.J., and C.R. Peterson. 1998. Amphibian and reptile distribution and habitat relationships in the Lost River Mount ains and Challis-Lemhi Resource Areas. Idaho Bu reau of Land Management, Boise, ID. Technical Bulletin No. 98-10. 56 pp.

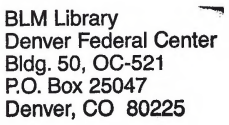

